University of Rhode Island

DigitalCommons@URI

Open Access Master's Theses

1997

\title{
IMPROVING OPEN-SPACE SUBDIVISIONS IN CHARLTON, MASSACHUSETTS: CONNECTING BACK TO THE LAND
}

Bruce E. Keller

University of Rhode Island

Follow this and additional works at: https://digitalcommons.uri.edu/theses

\section{Recommended Citation}

Keller, Bruce E., "IMPROVING OPEN-SPACE SUBDIVISIONS IN CHARLTON, MASSACHUSETTS:

CONNECTING BACK TO THE LAND" (1997). Open Access Master's Theses. Paper 384.

https://digitalcommons.uri.edu/theses/384

This Thesis is brought to you for free and open access by DigitalCommons@URI. It has been accepted for inclusion in Open Access Master's Theses by an authorized administrator of DigitalCommons@URI. For more information, please contact digitalcommons-group@uri.edu. 
HT168

C37

K45

1997 


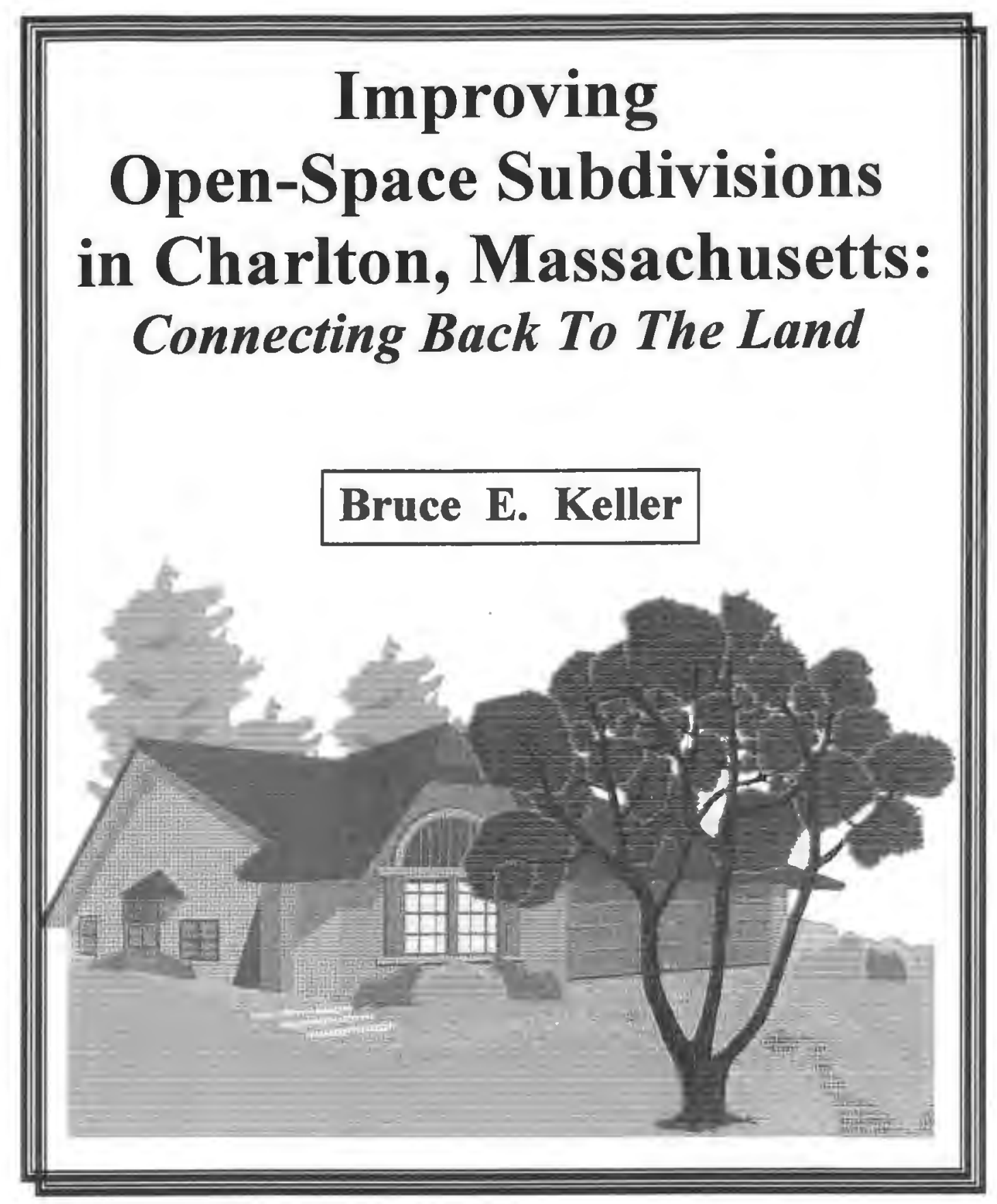

A Research Project Submitted In Partial Fulfillment Of The Requirements For The Degree Of:

MASTER OF COMMUNITY PLANNING

University of Rhode Island

1997 


\section{Improving Open-Space Subdivisions in Charlton, Massachusetts: \\ Connecting Back To The Land}

BY

Bruce E. Keller

A Research Project Submitted In Partial Fulfillment Of The Requirements For The Degree Of:

MASTER OF COMMUNITY PLANNING

University of Rhode Island

1997 


\title{
MASTER OF COMMUNITY PLANNING RESEARCH PROJECT
}

\author{
$\mathrm{OF}$
}

Bruce E. Keller

Approved:

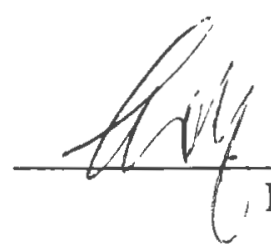

, Rolf Pendall, Major Professor

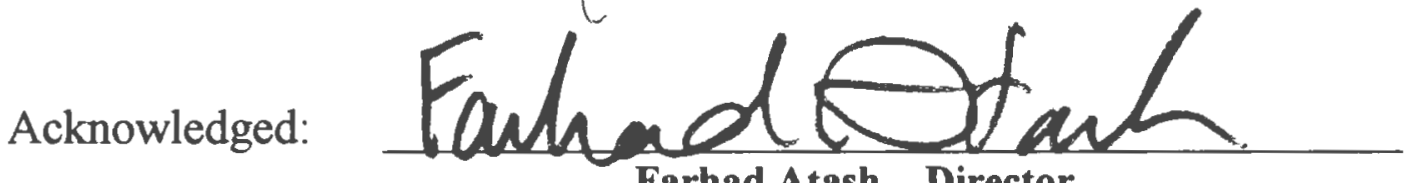

Farhad Atash, Director 
Dedicated to my supportive family: my wife Donna, and our children Adam and Cassie.... 


\begin{abstract}
In Charlton, Massachusetts, the current open-space subdivision option doesn't work well for the benefit of people or wildlife, but rather allows the developer to cut costs without giving a more beneficial design in return. Open space "islands" are being created that have no connectivity with one another, making them little more than buffers of undisturbed land within and among developments. While these buffers are somewhat useful from an aesthetic perspective, better regulations and design guidelines would be helpful in creating more useable "corridors" for wildlife and trails for people, which in return will help to preserve wildlife biodiversity and provide meaningful recreational opportunities for residents. Fragmentation of contiguous wildlife habitat is a major cause of local declines in wildlife species. Continuing along with the status quo would perpetuate inefficient stewardship of natural resources, continue the building of subdivisions where people are separated from nature, and force local wildlife into either finding new habitat or into facing decline and eventual extinction through genetic degeneration.

This study utilizes a multi-layered methodology to understand the issues: casestudies of existing open-space developments in the town of Charlton; the latest research from the preservation of biological diversity; an adapted Ian McHarg environmental overlay analysis method; and the Conservation-Subdivision design method recently put forward by Randall Arendt. These methods are then used in concert to look at a current Charlton subdivision project, Schofield Heights, to field-test the learnings from the project. Feedback is then utilized from the new designs to compare Charlton's existing open-space development regulations with the theoretical knowledge having been gained, whereby final recommendations for Charlton's regulations are made. The study concludes that if support from the local Planning and Conservation offices is provided to ease the extra design work inherent in these projects, that the benefits derived from this type of open-space subdivision planning exceed the costs for all involved.
\end{abstract}




\section{Contents}

iii

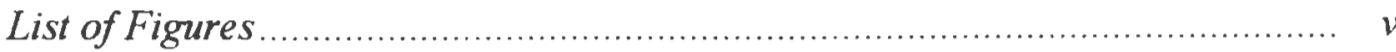

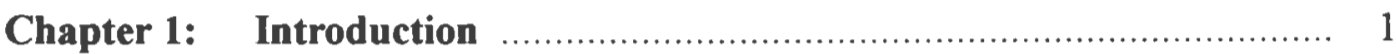

Chapter 2: Open-Space Subdivision Development in Charlton:

Promise and Reality .................................................... 11

Chapter 3: Reconnecting People with Nature:

The Need For Natural Resource Stewardship ................... 22

Chapter 4: Concepts To Consider:

Designing “Connection” into Open-Space Subdivisions ........ 38

Chapter 5: Proposed Open-Space Design:

Schofield Heights ..................................................... 65

Chapter 6: $\quad$ Findings and Recommendations …................................ 82

Chapter 7: Conclusion ..................................................... 89

References

Appendix A: Charlton's Current Flexible Development Bylaw ................... 95

Appendix B: More Information about the Quinebaug \& French River Basins ... 99

Appendix C: Schofield Heights: Analysis Phase Layers …....................... 101

Appendix D: LSA Septic System Design Calculations .......................... 113

Appendix E: Feedback Interview Notes ............................................ 116

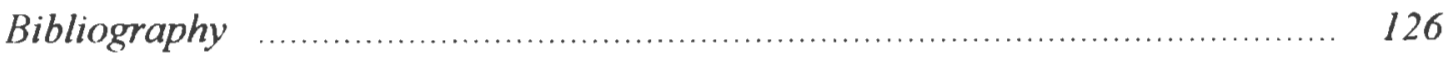




\section{List of Figures}

Page

Figure 1 - $1 \quad$ Location of Charlton, MA …...................................... 5

Figure 1 - 2 Zoning Map of Charlton, MA …................................... 7

Figure 1-3 Watershed Map of Charlton, MA ...................................... 9

Figure 1 - 4 Aquifer Location in Charlton ....................................... 10

Figure 2 - 1 Flexible Development Performance Standards ...................... 12

Figure 2 - 2 Comparison of Charlton Subdivision Options …...................... 13

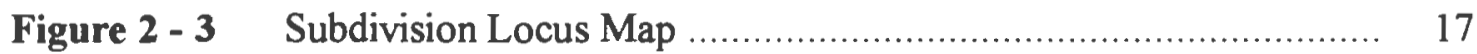

Figure 2 - 4 Solar Heights and its Environs ................................... 18

Figure 2 - $5 \quad$ Solar Heights - Design .............................................. 19

Figure 2 - 6 Henry Richards Circle and its Envitrons ............................. 20

Figure 2 - 7 Henry Richards Circle - Design ...................................... 21

Figure 4-1 Overall Streetscape Concepts ......................................... 53

Figure 4-2 Double-Loaded + Single Loaded Streets ............................ 54

Figure 4 - 3 a,bSpace-Saving Cul-de-Sac Designs with Landscaped Islands......... 55

Figure 4-4 Layout of Conservation + Open-Space Areas ........................ 58

Figure 4 - $5 \quad$ Layout of House Lot Patterns ......................................... 59

Figure 4 - 6 Layout of Streets and Nature Trails .................................. 60

Figure 4- $7 \quad$ Layout of Lot Lines ........................................................ 61

Figure 4-8 Proposed Cul-de-Sac Design Concept …............................... 63

Figure 4 - 9 Proposed Charlton Open-Space Design Requirements ................ 64

Figure 5 - 1 Location of Schofield Heights in Charlton ….......................... 70

Figure 5 - 2 Analysis: Nearby Natural/Cultural Resources ........................ 71 


\section{List of Figures (con't)}

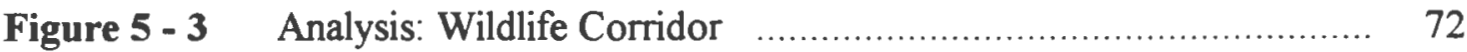

Figure 5 - 4 Results of Nearby Natural/Cultural Resources + Wildlife Corridor 73

Figure 5 - $5 \quad$ Analysis: On-Site Natural + Cultural Features ......................... 74

Figure 5 - 6 Results of On-Site Natural/Cultural Resource Analysis .............. 75

Figure 5 - 7 Lot Yield Plan (with conventional development) ....................... 76

Figure 5 - $8 \quad$ Layout of Conservation Areas .......................................... 77

Figure 5 - 9 Scheme 'A' - Layout of Houses, Active Open Space, Roads/Trails. 78

Figure 5 - 10 Scheme 'B' - Layout of Houses, Active Open Space, Roads/Trails 79

Figure 5 - 11 Final Design: Open Space Scheme 'A' ............................ 80

Figure 5 - 12 Final Design: Open Space Scheme 'B' ................................. 81

Figure 6 - 1 Schofield Heights: Comparison of Design Approaches ................ 83 


\section{Ch. 1}

\section{Introduction}

For many of us, Milk comes from Stop \& Shop, Flowers come from the corner vendor, $\boldsymbol{T}_{\text {op-soil }}$ can be bought at the hardware store, and $\boldsymbol{T}_{\text {rees }}$ can be

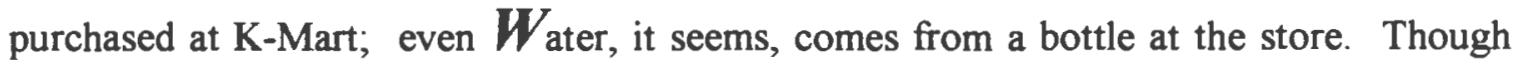
humans deal with two realms: abstract and physical, it is fair to say that many of us have unlearned how to deal directly with the natural world around us; we have forgotten our ties to the land.

Regrettably, we have also unlearned our need for the land to sustain us, and our need to develop upon the land lightly. Taking down a few acres of woods seems harmless enough; after all trees can be replaced (from K-Mart!), but only recently have we begun to understand the critical nature of vegetative habitat, and the interdependence of species diversity to that habitat. The recent name for this relationship is biodiversity.

\section{The Problem: Disconnection and Fragmentation}

Land development in the United States and elsewhere has had major impacts on the natural environment. Development can cause major physical changes upon the landscape, including substantial reduction in plant and tree vegetation, and in wildlife habitat (Marsh 1991, Beatley 1994, Orians 1995). This development has often led to the inadvertent creation of habitat and vegetation "fragments", which reduces biodiversity, one of the key aspects of environmental sustainability (Wilson 1989, Farber 1991, Holt et al. 1995, Orians 1995)

While it seems clear to us to be more concerned about the on-going destruction of 74,000 acres of tropical rain forest each and every day (Chiras 1992), it is harder to see that with our current development practices here in New England, that today's forest and 
wetland habitats are becoming more fragmented. Ironically, more of New England is covered with forest today than was the case 100 years ago (Cronon 1983, Easterbrook 1995), but with the increase in human population and constant suburban sprawl, there is less room today for careless land development than in the past, we are again eroding the stamina of our own landscape.

\section{Significance of The Problem}

Charlton's cluster/open-space subdivision option doesn't work well for the benefit of either people or wildlife, but rather allows the developer to cut costs without giving a more beneficial design in return. Open space "islands" are being created that have no connectivity with one another, making them little more than buffers of undisturbed land between developments. While these buffers are somewhat useful from an aesthetic perspective, better regulations and design guidelines would be helpful in creating more useable "corridors" for wildlife and trails for people, which in return will help to preserve wildlife biodiversity and provide meaningful recreational opportunities for residents. Fragmentation of contiguous wildlife habitat is now a major cause of declining wildlife species. Continuing along with the status quo would perpetuate inefficient stewardship of natural resources, and continue the building of subdivisions where people are separated from nature.

\section{Objectives for This Study}

In this critical study of open-space subdivision development in Charlton, Massachusetts, we will briefly review the reality of the town's existing open-space subdivisions regulations. And in the remaining chapters of the project, we will explore a renewed stewardship of the natural environment, utilize new understandings of biological diversity, learn regulatory requirements established in the state for conservation purposes, discuss the provision of contiguous wildlife habitat corridors, and uncover techniques to 
help physically reconnect people to the landscape around them. This new knowledge will be modeled in a proposed change to the Charlton Zoning bylaw for open-space subdivisions, and then utilized in a subdivision design that incorporates the proposed changes.

\section{Study Overview and Methodology}

The study is organized into four parts: Problem Identification (Chapters 1 and 2); Review of the Literature (Chapter 3); Application of Learning (Chapters 4 and 5); and Synthesis (Chapters 6 and 7). In this introductory chapter, we have briefly explored the broad problem of being disconnected from our surroundings; the remainder of chapter one will be an introduction to the town of Charlton, Massachusetts in its geographic context. Chapter 2 introduces the reader to two of Charlton's cluster/open-space style subdivisions, which began under the premise of better preservation of open-space values, but may not be accomplishing these goals very well nor connecting people with the open space made available in these projects.

The Need For Natural Resource Stewardship is the third chapter; this literature review argues that we can no longer think of the natural environment as something "out there", but rather as something we need to be connected in order to live sustainably in the world; and something we need to proactively plan for.

Part three begins with chapter four, where the study looks at various techniques, strategies, and regulations that can be used together to re-connect people to the land and each other as we create open-space subdivisions. Chapter five takes all the previous arguments and learnings and applies them to an actual, forthcoming subdivision project in Charlton, Schofield Heights, where a large, 100 acre parcel of land will be designed with wildlife habitat conservation and connection to our environment in mind.

Synthesis, the last part of the study, begins with chapter six, which solicits feedback from developers and town officials as to the results of the endeavor. This 
"ground-testing" focuses the project fully onto the realities of development. Finally, chapter seven summarizes learnings and makes recommendations for changing Charlton's current regulations.

\section{Methodology}

First, brief case studies will be used to review two existing cluster/open-space development subdivisions in Charlton, broadly comparing them against some of the ecological principles that will be focused on throughout the remainder of the study.

Second, an existing parcel of land in Charlton, already identified by the owner as intended for subdivision, will be selected to utilize ecological principles discussed in the literature review, along with an adaptation of McHarg's overlay mapping method (1991), and conservation subdivision layout techniques from Randall Arendt (1996). This work will culminate into two open-space design alternatives for this forthcoming Charlton subdivision project, hopefully providing some useable ideas for the forthcoming project.

Finally, from the learnings of this study will come a review of the existing zoning regulations in Charlton regarding cluster/open-space subdivisions, with recommendations for needed changes.

\section{The Context: Charlton, Massachusetts}

Located 15 miles southwest of the city of Worcester (see Figure 1-1), the town of Charlton has one of the largest land areas in Worcester County - 44 square miles. Between 1970 and 1990, population doubled from 5,000 to 10,000 people, and the State predicts that Charlton's population will continue to grow by about 25 percent between 1990 and the new millennium.

State and federal policies, as well as intra-state migration are bringing major changes to the community. Mandated sewer plant and piping upgrades, Mass. Title-V septic system regulations, a new $\$ 27$ Million dollar middle school, future funding requirements for Mass. Education Reform, a \$200 Million dollar electric power plant 
wanting to locate here (due to impending deregulation of the electric industry), and new wireless telecommunications towers being erected (due to the Federal 1996 Telecommunications Act), are besieging this sleepy rural town. These impacts are beginning to divide Charlton into a number of different camps, those that don't want any changes (that will ruin their rural community), those that want economic development, and those that want to find a balance that fits with the reality of the times.

Until recently, town government has been run by a small, mostly volunteer caretaker regime (Ramsey 1996), consisting of a 3-member board of Selectmen (now Selectwomen as well), and elected or appointed committees and commissions. In 1990, the town began to use part-time professional planning staff, and in 1996 hired its first fulltime town planner. A professional town engineer will be hired in 1997, and discussions for hiring a town administrator are debated in Town Meetings.

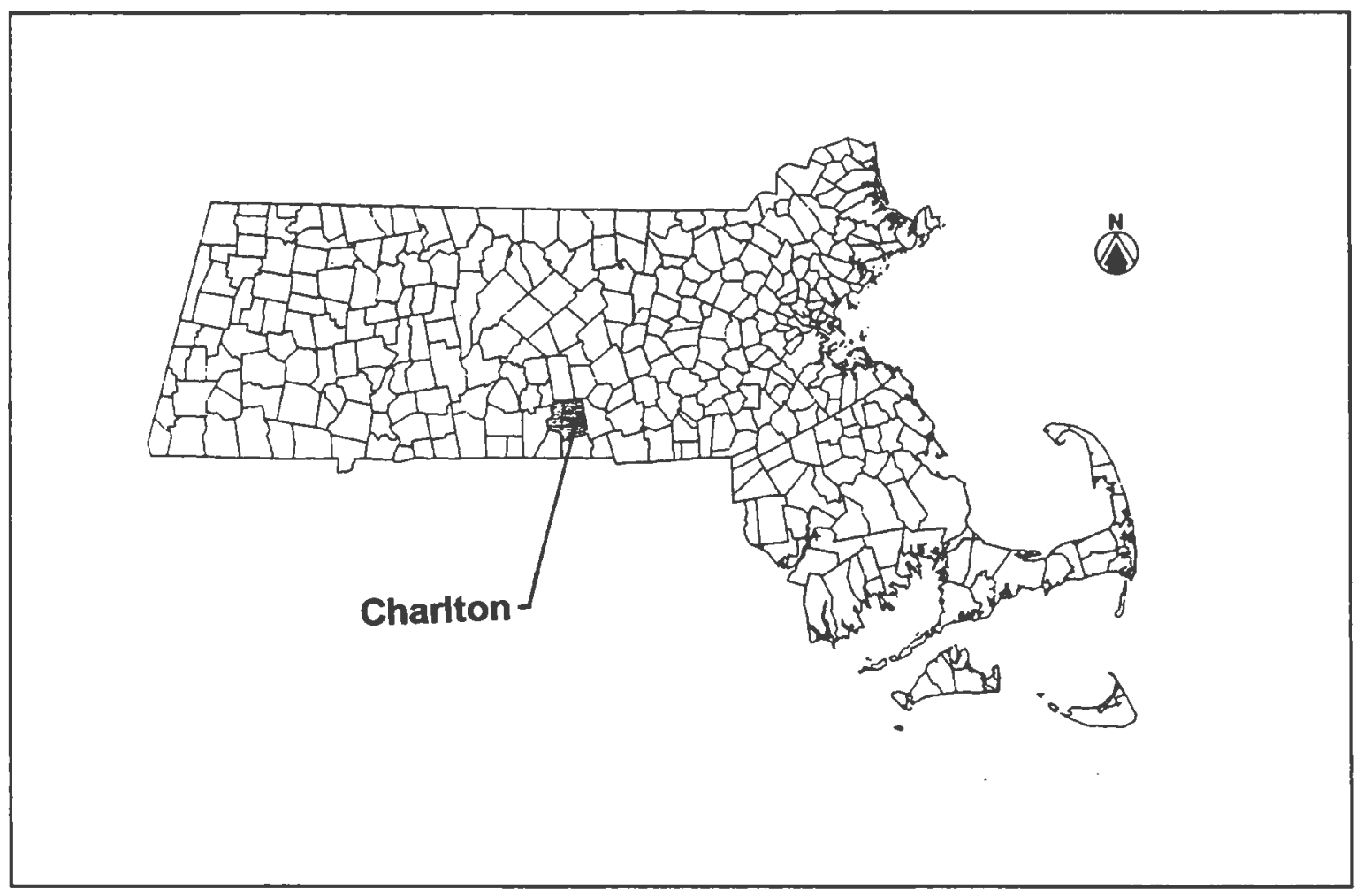

Sourc: MassGIS

Figure 1-1 Location of Charlton, MA 
Taking a look at the town zoning map in Figure 1-2 (Charlton has only had a zoning bylaw in place since 1987), one can see that about 80 percent of the community is zoned 'A' (Agricultural). Also of interest is how the IG (Industrial General), IP (Industrial Park), and $C B$ (Community Business) zoning districts are set up along the two major road corridors in town: Route 20, which runs east-west, and Route 169, which runs southwest from Route 20 (slightly west of the center of town). Route 20 is a concern from a zoning perspective, with its 400 foot deep CB district running through most of the town; it has the making of one big strip mall! Lack of town sewer and water, and lower-than-desirable traffic counts by the major retail chains are the primary reasons it hasn't yet been developed. There are no national retail chains in Charlton today.

Highlighting the largest zoning district in Charlton, the Agricultural zoning district is a rural residential density zone requiring a minimum of 60,000 square feet for a single parcel, with a minimum road frontage width of 175 feet. The intent and purpose of the Agricultural district, according the Zoning Bylaw is:

To provide for agricultural and lowest density residential sites while at the same time encouraging open space, preserving or enhancing views, protecting the character of the historic rural and agricultural environs, preserving or enhancing visual landscapes, recognizing site and area limitations for on-site waste water disposal systems in terms of drainage, soil suitability, proximity to surface and aquifer and other sub-surface water resources, and slope. ( Sec. 3.1.5.1)

(See Zoning Map on Next Page) 


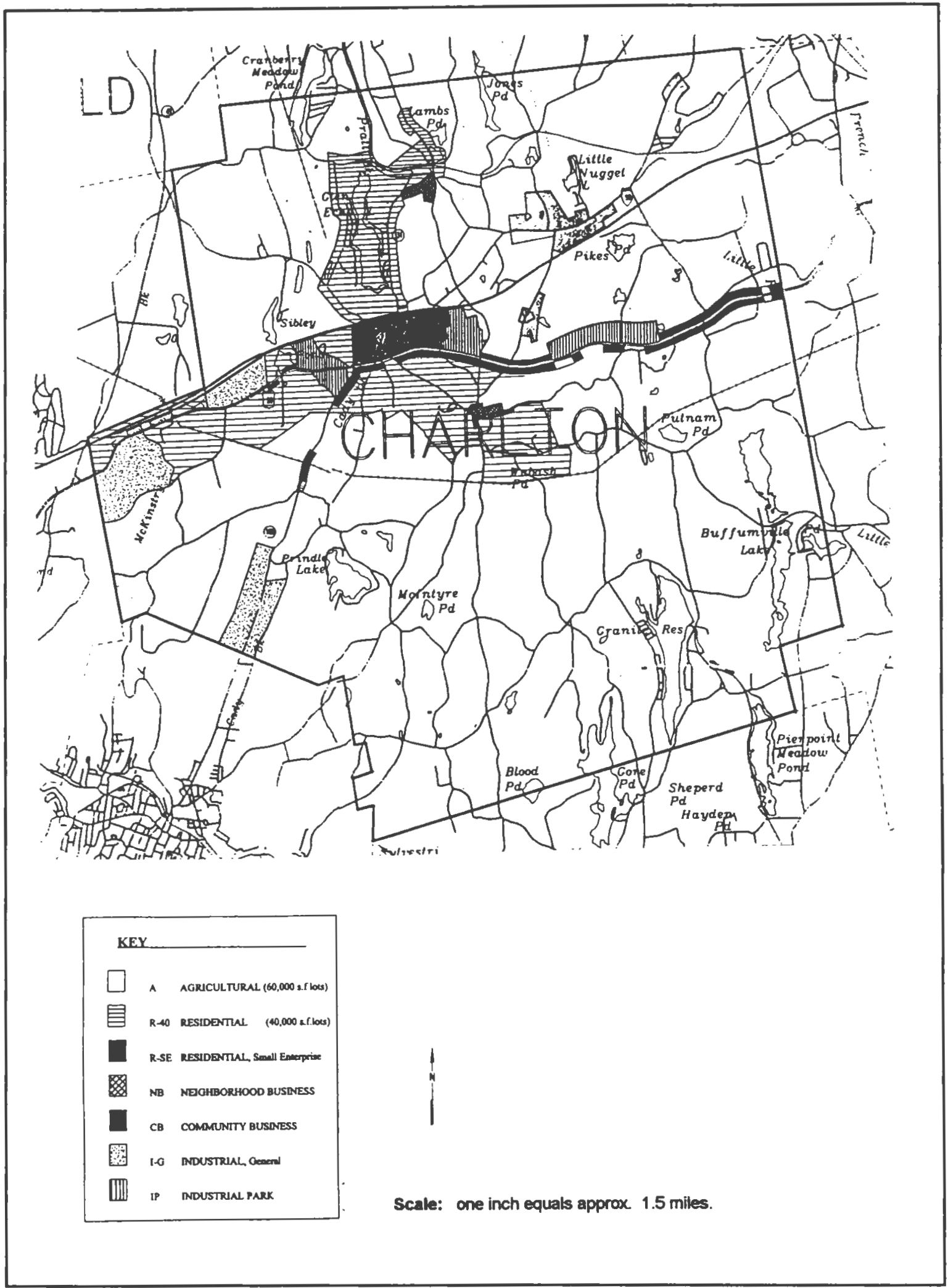

Source: Adapted from Town of Chartion 1996 Open Space Plan

Figure 1-2 Zoning Map of Charlton, MA 


\section{Geography}

Physiographically, Massachusetts is part of the Appalachian Highlands region, formed by metamorphic and intrusive igneous rocks (Espenshade and Morrison 1978). It should come as no surprise then that Charlton's terrain is hilly, with numerous wetlands, streams, small ponds and lakes. Two small rivers, Cady Brook and Little River, flow north-to-south through the community. For the most part, the soils offer poor drainage characteristics throughout the town, as evidenced by a good deal of rock ledge several feet below the surface.

At the watershed level, Charlton is part of the Quinebaug and the French River basins, both of which are tributaries to the Thames River in Connecticut This drainage area covers 251 square miles in Massachusetts, and 1474 square miles total (Bickford and Dymon 1990). Two small streams, Cady Brook and McKinstry Brook, act as tributaries to the Quinebaug River; another stream in Charlton, called Little River, is a tributary to the French River (see Figure 1-3, and Appendix 'B' for additional information).

Reviewing the latest aquifer information, Charlton has a one medium-yield gravel and sand aquifer, located in southeast Charlton, in the Buffumville Lake area; it is not presently being used for public water supply needs (see Figure 1-4). No public infrastructure currently exists for water in the town; all properties are on well water . 
Introduction

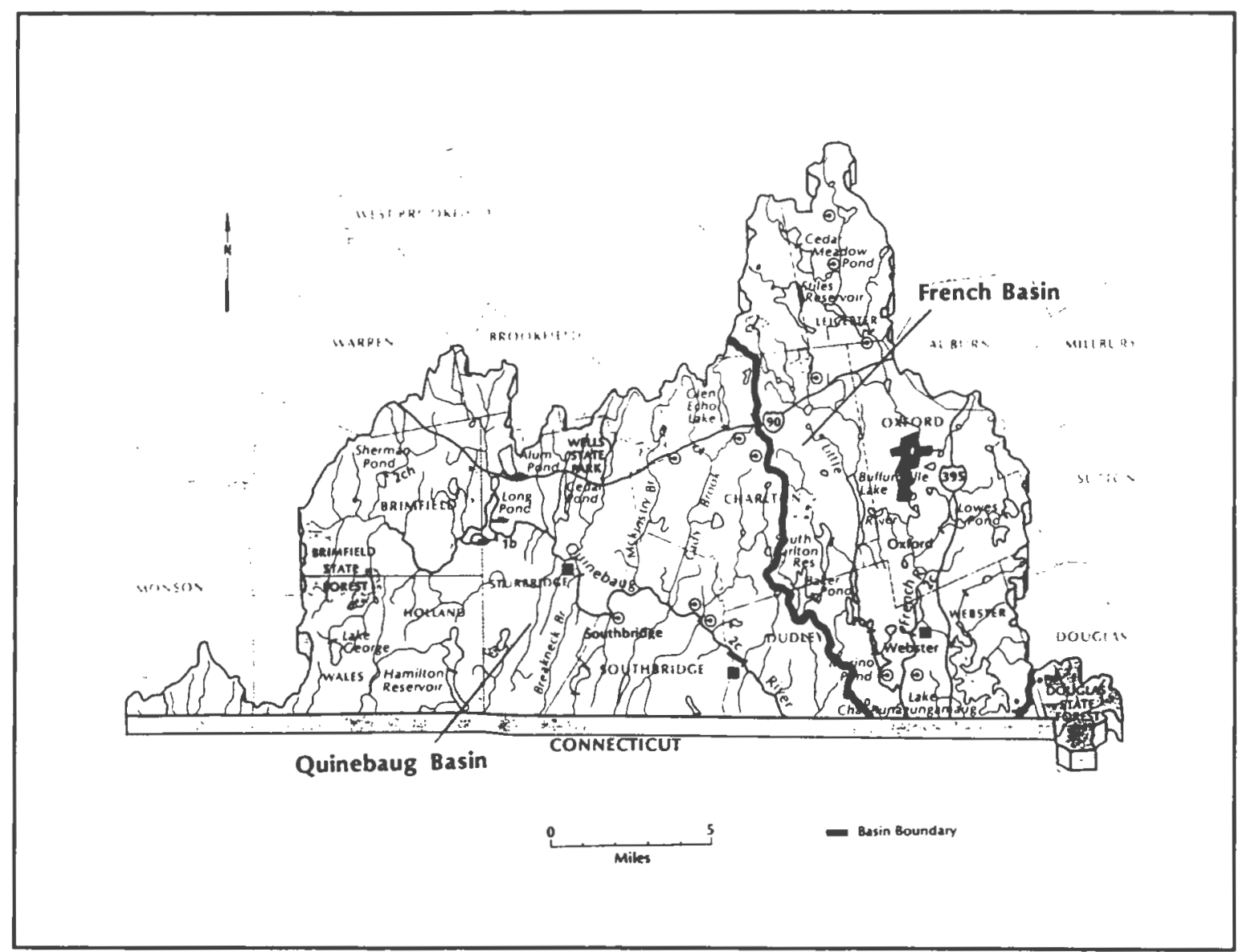

Source: Bickford, WE and U.J. Dymon, eds. 1990. An Atlas of Massachusetts River Systems: Environmental Designs for the Furure. Amhers, MA: Univ. of Massachusetts Press, p.49.

Figure 1-3. Watershed Map of Chartton, MA 


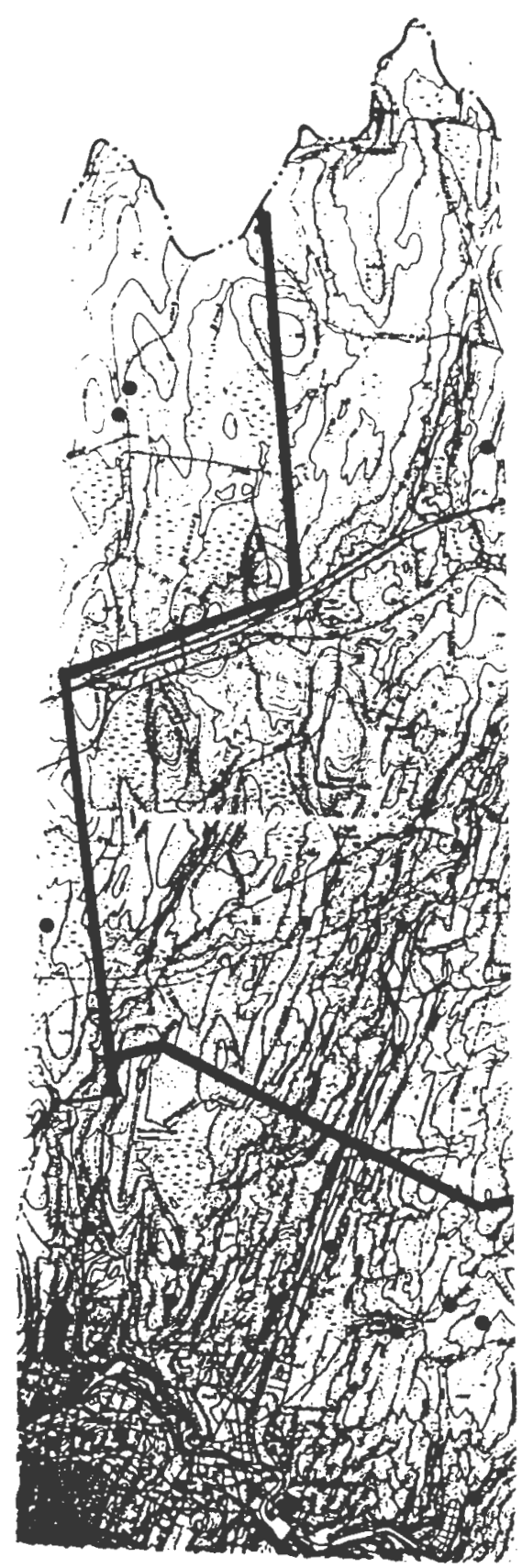

EXPLANATTON

AREAS OF AVALABLE GROUND WATER

AND ESTDMATED YIED DO

PROPERLY DESIGNED AND CONSTRUCTED WELLS

Genenally greater then 300 gallone per minuta from an aqulier having an ertimated transmisettsty greater than 4.011 feet squared per day

Generally between 100 and 300 gallons per minute from in equller having an oodmoted transmledvity between 1,337 and 4,011 feet uquared per day

Fich Generally bxtween 10 and 100 gallons per minute from in aquiles having an estimated transmisedvity between 134 and 1,337 feet squared per doy

Generally lest than 10 gallons per minute trom till or bedrock having an extmited tranemlestuty between 0.1 and 134 feet quared per day

(1) Munkejpal well or well theld finlehed in unconsotidated deposts

C Munkepal well or well feld Anished in bedrock

- Welf or boring finlshed in unconsolidated deposits

- Well or boring inished in bedrock

- Well or boring that reached bedrock or relusal

-.. B- Bedn boundary

\section{Charlton}

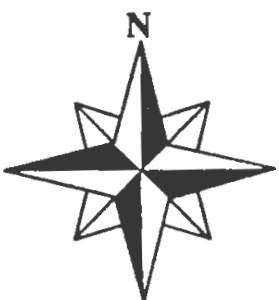

\section{IMPROVING OPEN-SPACE SUBDIVISIONS IN CHARLTON}

Figure 1 - 4

\section{Aquifer Location in Charlton}

Source:Water Resources in the French-Quinebaug Rlvers Basin, Mass. Mass. DEM, Dlv. of Water Resources 1988 


\section{Ch. 2}

\section{Open-Space Subdivision Development in Charlton: Promise and Reality}

In the State of Massachusetts, municipalities are authorized through the state zoning act known as Chapter $40 \mathrm{~A}$ to allow the option of cluster development subdivisions through special permit. Charlton has adopted this provision, calling their version of it the "Flexible Development"; a developer who opts to use this provision of the town's zoning bylaw goes through both a special permit process and a subdivision review process. These are typically done concurrently to save time and duplication of efforts.

Looking at the promise of Charlton's Zoning regulations, it states in the Purpose and Applicability portions of its Flexible Development bylaw that:

The purpose of the flexible development option is to provide for the most efficient use of services and infrastructure, to maintain the Town's traditional New England rural character and land use patterns, and to encourage the permanent preservation of open space... agricultural land, forests and woodland, historic or archeological sites ... [By:] preserving land use patterns in which small villages contrast with open spaces, farmland and forests; preserving scenic vistas; providing for the most efficient use of municipal and other services; preserving unique and significant natural, historical and archeological resources; and encouraging a less sprawling form of development, but not to the extent that such development will visually and environmentally overwhelm the land. (Town of Charlton Zoning Bylaw, Sec.5.7.1, Sec. 5.7.2)

\section{The Reality}

Comparison of the important design provisions of the Flexible Development Option with that of Charlton's "conventional" subdivision regulations (Figure 2-1) reveals that while significant efficiencies are gained in terms of road widths and lot frontages, mechanisms and guidelines for purposefully designing flexible development subdivisions 


\section{Figure 2-1. Comparison of Charlton Subdivision Options}

Criterion

Conventional Developmet

Flexible Development

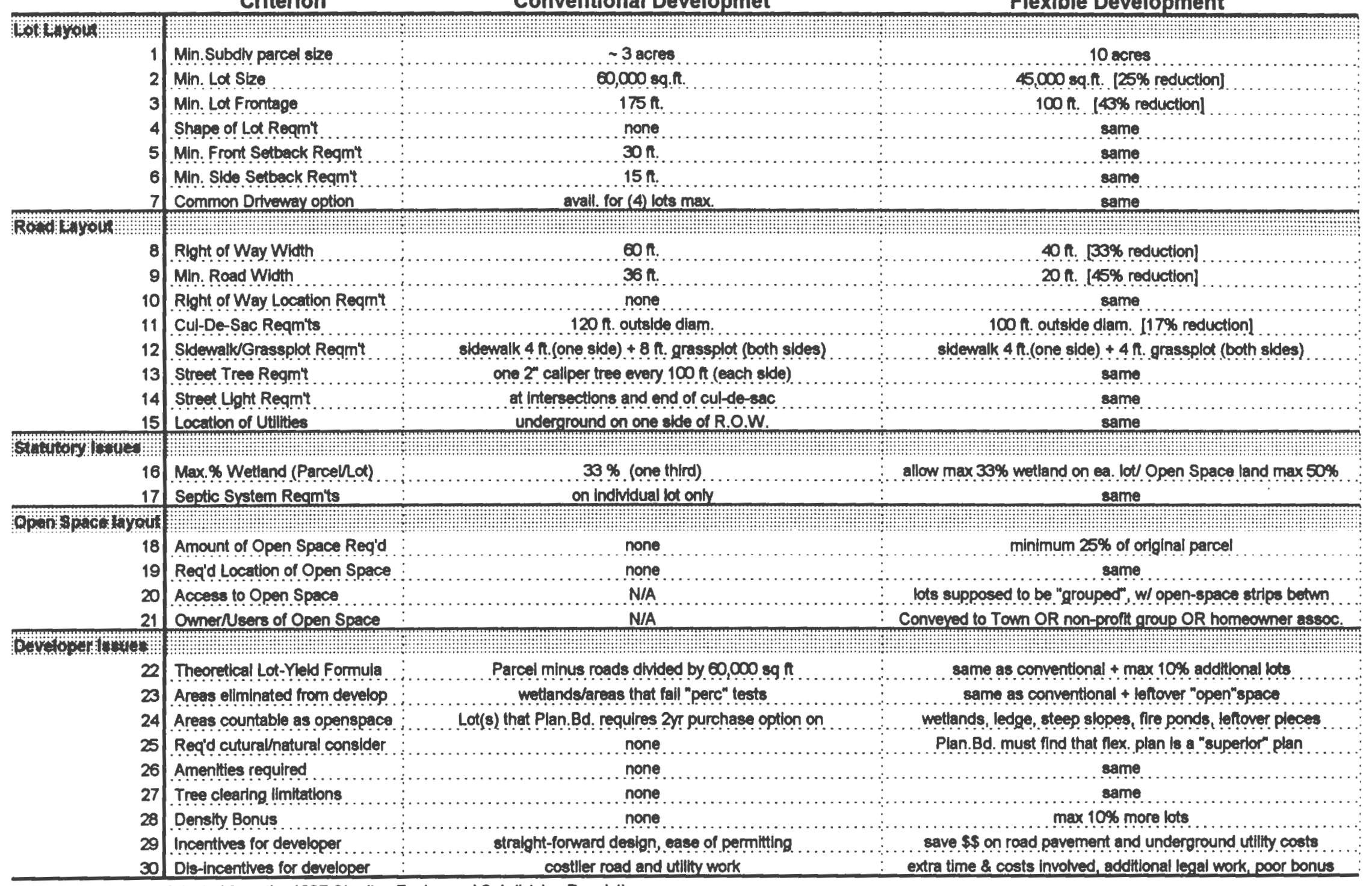


to better preserve forests, woodlands, scenic vistas, historical, and archeological resources are not adequately spelled out.

Performance standards are used instead, providing the developer (and more likely the developer's engineer) with an end result, but no detail to accomplish it. While the use of performance standards has been an important component of the planning "tool box" for many years (Kendig 1980, Arendt 1994), in Charlton's case it leaves the most important considerations for what constitutes appropriate open space, as well as where that open space is located, to the subdivision developer. The performance standards for Flexible Development can be seen in Figure 2-2 below (see Appendix ' $A$ ' for the complete Flexible Development Bylaw):

\subsubsection{Slandards}

5.7.3.1 Building lots within flexible developments shall conform to the following standards:

\begin{tabular}{|c|c|c|c|c|}
\hline Zoning & $\begin{array}{c}\text { Min. Lot } \\
\text { Area }\end{array}$ & & Setback & $\begin{array}{c}\text { Max } \\
\text { Building }\end{array}$ \\
\hline District & $(s q u)$ & Erontage & Eront Side Rear & Coverage \\
\hline A & 45.000 & $100^{\prime}$ & $\begin{array}{lll}30^{\prime} & 15^{\prime} & 30^{\prime}\end{array}$ & $30 \%$ \\
\hline$R-40$ & 30,000 & $100^{\prime}$ & $\begin{array}{lll}30^{\prime} & 15^{\prime} & 15^{\prime \prime}\end{array}$ & $30 \%$ \\
\hline R-SE & $30,000^{1}$ & $100^{\prime}$ & $30^{\prime} \quad 15^{\prime} \quad 15^{\prime}$ & $30 \%$ \\
\hline
\end{tabular}

1 Building lots may contain 20,000 square feet if connected to a sewer system.

$5,7.3 .2$ The lons within the flexible development used for residential structures shall be grouped, where each lot shall be contiguous. Every group shall be separated from every other group within any flexible development by a distance determined by the Plaming Board.

27.3.3 A strip of permanently restricted open space, the width of which shall be at the discretion of the Planning Board, shall be provided between every group and the exterior propenty lines of the flexible development parcel.

5.7.3.4 A minimum of $25 \%$ of the land area in the flexible development shall be permanently restricted open space and shall be suitable for recreational, agricultural or cultural uses. The Planning Board may require that at least fifty (50) percent of the permanently restricted open space shall be free from wellands as defined in the Wetlands Protection Ad. However, such open space may contain more than $50 \%$ welands if the additional open space consists of bodies of water.

5.7.3.5 The number of building lots proposed may exceed the number that would normally be allowed by a conventional subdivision plan in full conformance with zoning, subdivision regulations, health codes, wealands bylaws and other applicable requirements by $10 \%$ if the Planning Board finds that the character of the surrounding area would not be adversely affected thereby and that all other requirements of this section are met.

5.73.6 No lo shown on an approved flexible development plan shall be further subdivided and the plan shall be so noted. Relocation of lot lines, street layour and open space layout may be allowed after approval, provided that no increase in the number of building lots results thereby and provided further that approval of the Planning Board is given. If the Board determines that a proposed revision constitutes a substantial change, a public hearing shall be held at the expense of the applicant.

5.3.7 Streets constructed within the flexible development shall conform to the applicable requirements of the Rules and Regulations Governing the Subdivision of Land.

Source: Charton Zoning Bylaw

Figure 2-2. Flexible Development Performance Standards 


\section{The Result}

A review of Charlton Planning Board records shows that the Flexible Development option has been used for the design of four subdivisions to-date. Two of these have already been constructed, a third was recently approved; a fourth proposal was preliminarily approved by the Board but final plans were never brought forward.

The two subdivisions that have been constructed, Solar Heights and Henry Richards Circle, have been selected to briefly look at the results of following the Flexible Development bylaw. The locations of these subdivisions in Charlton are shown on Figure 2-3. The reason this option was chosen by the developers for these projects, and therefore the option's primary benefit to them is that significant dollars could be saved on road construction costs.

A look first at the objectives and performance standards of the flexible development option, and next at these two subdivisions that were completed shows that objectives are certainly met regarding efficient use of infrastructure and municipal services. Looking however at Figure 2-5 (Solar Heights) and Figure 2-7 (Henry Richards Circle), the designs barely meet the "less sprawling" form of development called for, and certainly do not meet the "preservation of land use patterns in which small villages contrast with open spaces, farmland and forests"; nor do they preserve "unique and significant natural ....resources". Specifically, the results of the designs show that contiguous areas of wildlife habitat are compromised, people are cut-off from the open space made available for them, and people are cut off from one another. These 3 issues will now be reviewed.

\section{Contiguous Wildlife Habitat is Compromised}

In both subdivisions important consideration of adjacent streams and/or wetland areas to preserve wildlife habitat was not undertaken. Putting open space next to these areas would have left a wider wildlife corridor as the land was developed. 
Fragmentation of open space/wildlife habitat is also a concern. In the case of Solar Heights, open space is fragmented into two sections, with only a 25 foot strip of land connecting them.

\section{People: Cut Off from Open-Space}

In both subdivisions, access to the open space as well as identification of it are items not readily made available all the residents. The pathways or sidewalks that exist in both developments either do not go near the potential open space access (Henry Richards Circle), or they are not available to all residents (both). Potential access points are not identified, and nature trails do not exist in either project that would entice residents to directly experience their surroundings through the open space that is preserved.

\section{People: Cut Off from One Another}

Building orientation, front setbacks from the street, treed sidewalks or walkable streets, and pathways through open space are important elements that can bring people closer together in community (Listoken and Walker 1989, Rowe 1991, Jarvis 1993, Arendt 1994).

In both of these projects, the houses are not at all oriented toward one another in any kind of cluster, as hinted at in section 5.7.3.2 of the bylaw. "Cookie-cutter" lots facing the streets, however, are standard fare for the lots in Solar Heights; and although the lots in Henry Richards Circle face wooded open space in the middle of the cul-de-sac, they are set back about 200 feet from the street. Houses in Solar Heights are set back 50 feet from the street, but in either development anyone walking by who wanted to casually say hello to their neighbor in passing would be forced to raise their voice significantly or be resigned to just waving.

In Charlton's subdivision regulations, sidewalks are required on only one side of the street, presenting acute problems around cul-de-sacs, and general problems around the remainder of the development, as evidenced with the two projects chosen for this study. The 600 foot sidewalk in Henry Richards Circle is a good example, it primarily (perhaps 
exclusively) benefits one out of the eleven homes in the subdivision! These sidewalk arrangements discourage residents from walking around their neighborhood. In Solar Heights, for example, a pathway could have been created between the two cul-de-sacs, but wasn't, another opportunity missed.

\section{Drawings for Solar Heights and Henry Richards Circle}

The remainder of this chapter contains a locus map of where the projects are located, and 2 drawings for each development: one showing the project in its nearby environs, and a second drawing showing the issues highlighted in the previous pages, such as subdivision lot configuration and locations homes and open space.

Schedule of Drawings:

Figure 2-3 Locus Map

Figure 2-4 Solar Heights and its Environs

Figure 2-5 Solar Heights - Design

Figure 2-6 Henry Richards Circle and its Environs

Figure 2-7 Henry Richards Circle - Design 


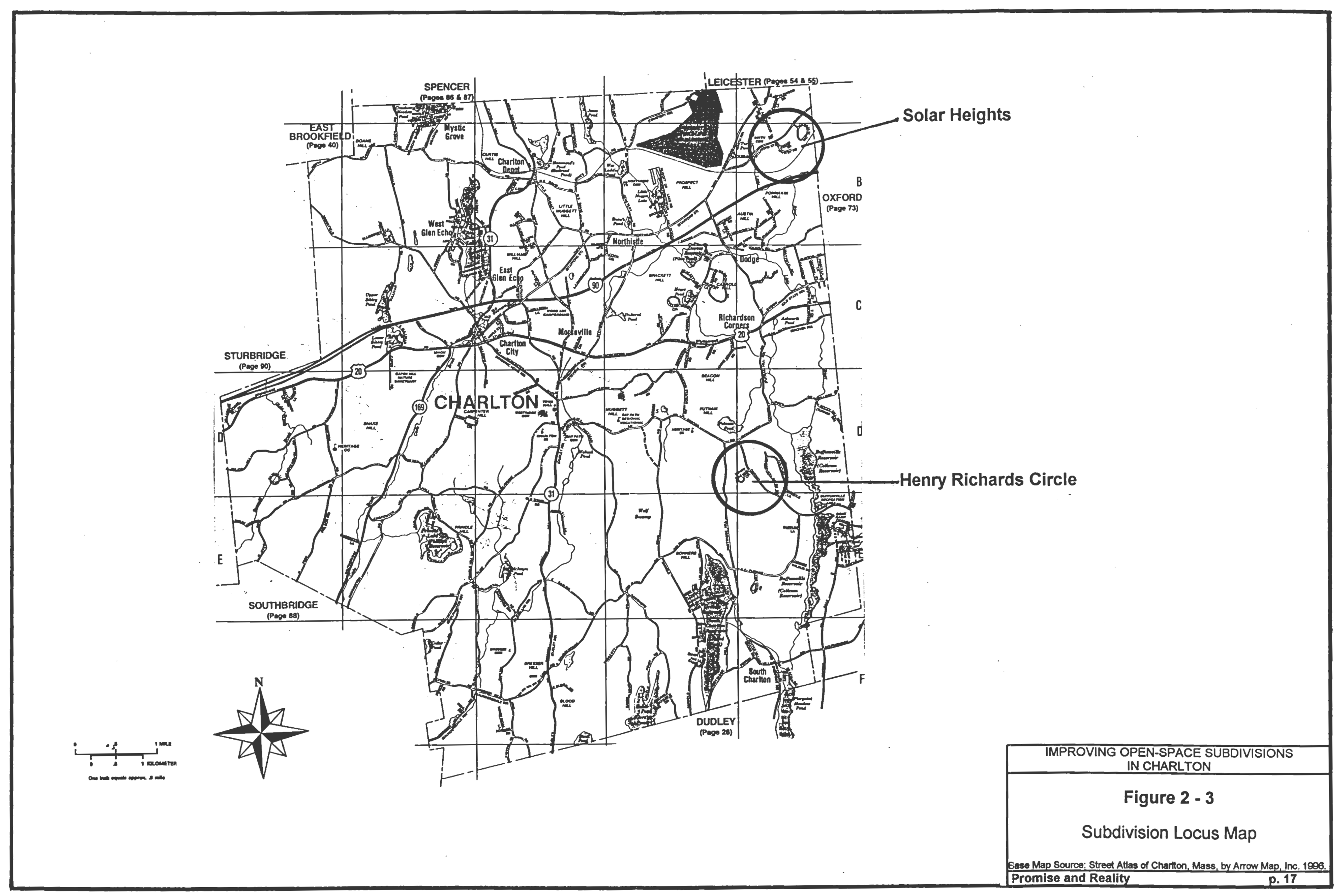




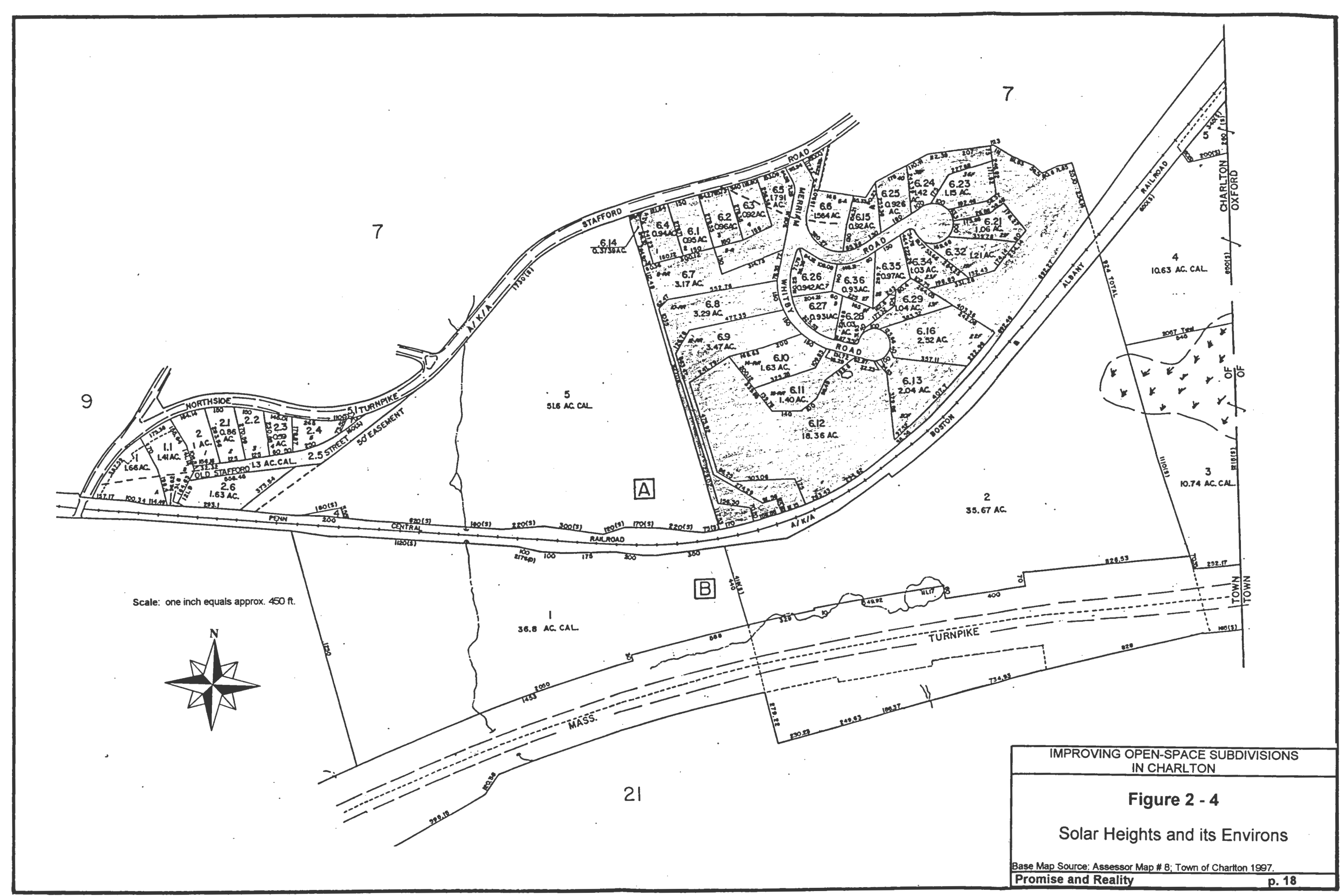




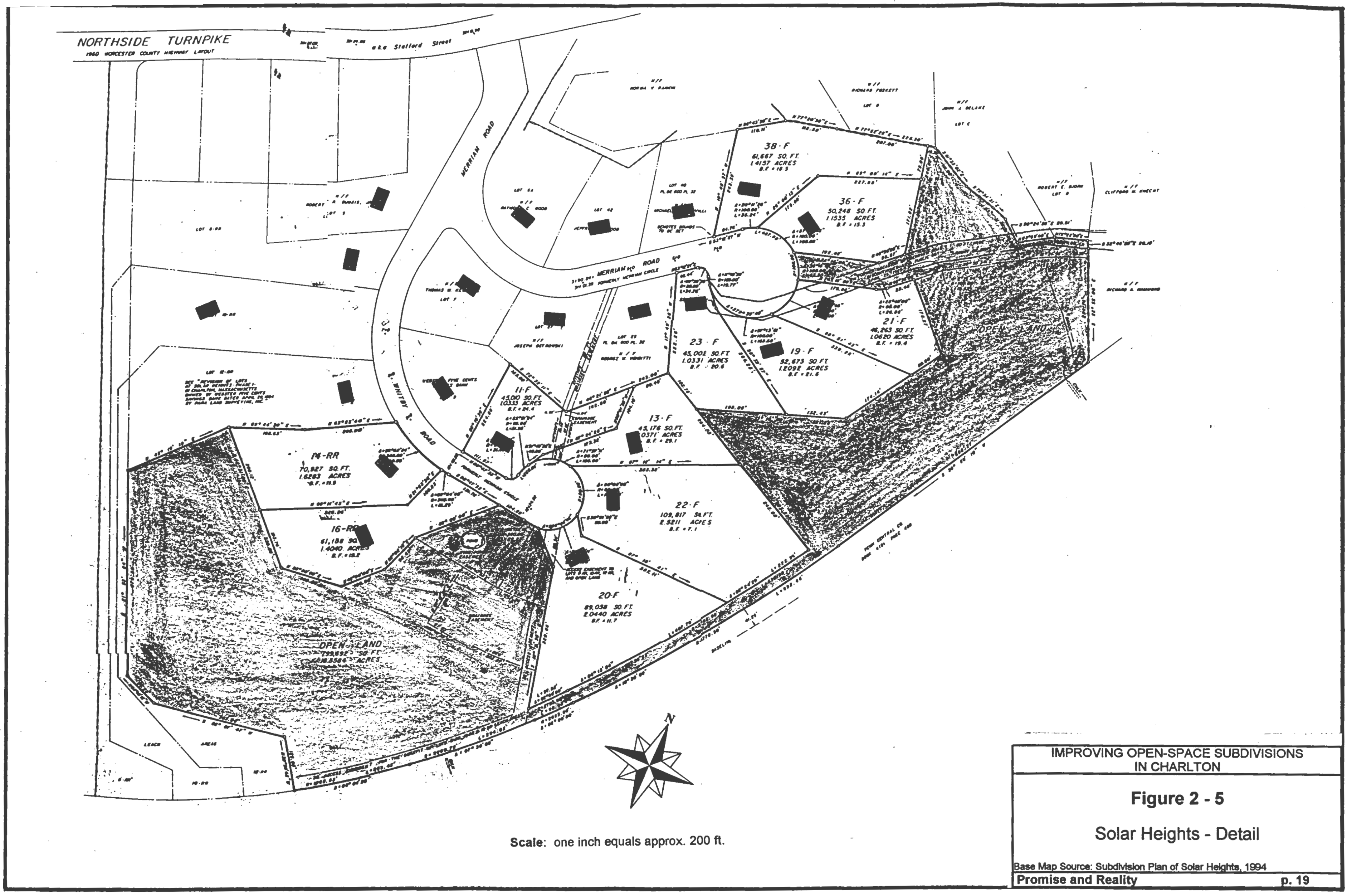




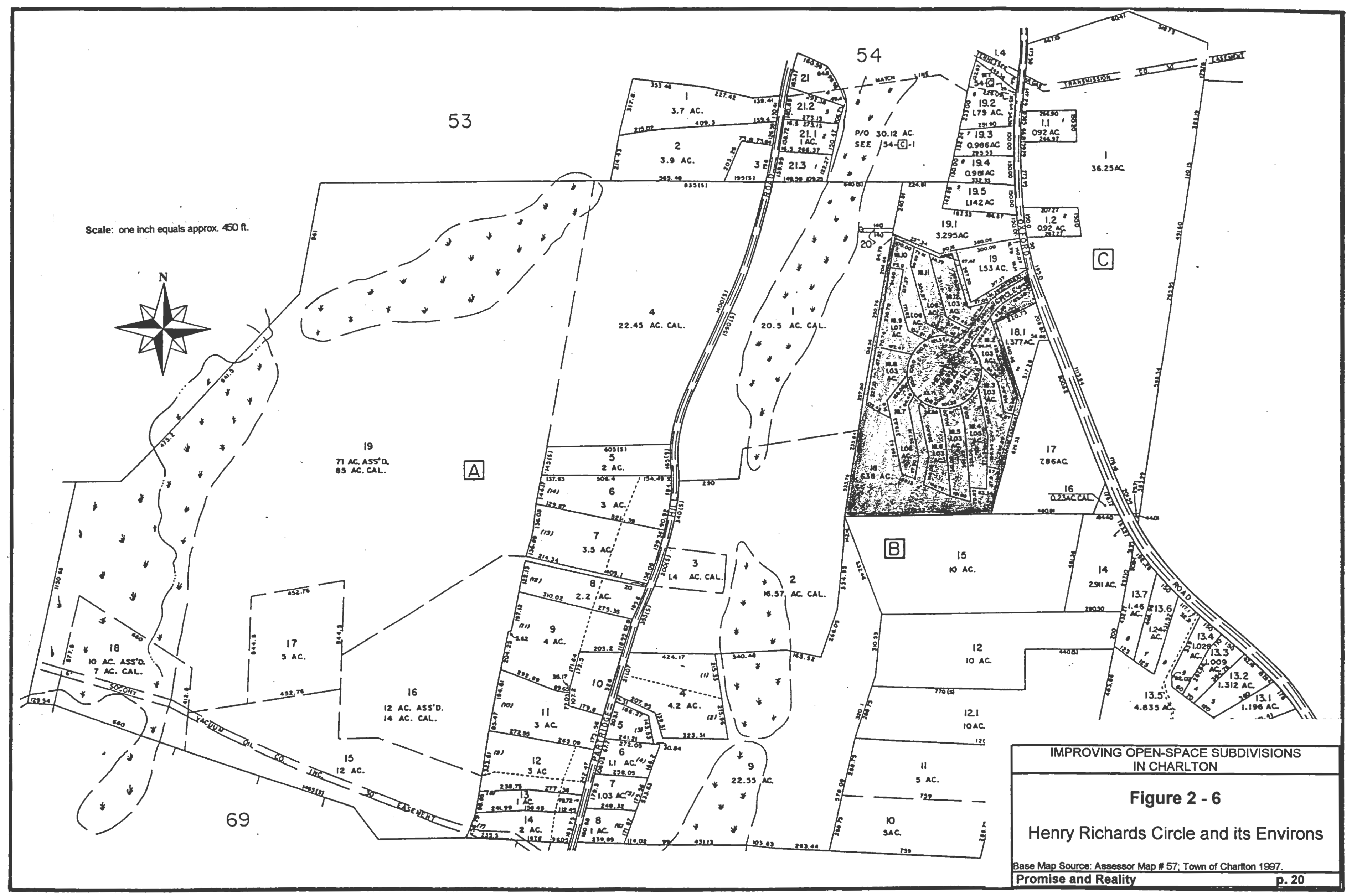




\section{Ch. 3}

Reconnecting People with Nature: The Need For Natural Resource Stewardship

The argument to be made for revising the approach to open-space subdivisions in Charlton is that we can no longer think of the natural environment as something "out there", apart from us. We are ultimately dependent upon clean water, fertile soil, wetlands, forests, and clean air for human survival, and as more of us populate the globe (and Charlton as well), it becomes critical to understand how these resources work, how they are being impacted, and ways to preserve them sustainably for current and future generations.

This chapter starts off globally, then turns to thinking regionally about what needs to be done. Chapter four discusses what can be done locally in subdivisions to both support the regional ecology and create a closer connection to the environment, utilizing these broads concepts and some Massachusetts regulatory tools currently available to assist this effort.

However tenuous, there appears to be an environmental ethic shaping land-use processes and decisions. In the corner of the world that is Charlton, where growth is beginning now to take hold, it is argued by this project that thinking sustainably and being good stewards of the land are important components of this new land ethic. There is some good news these days in southern New England: woodlands have returned to nearly threefifths of the region, black bears are prevalent, and coyotes now live in many communities (McKibbon 1995). The critical thing now is to take advantage of this rebirth; and as developmental growth occurs in the community, we should deliberately plan for the future of the environment instead of assuming it will take care of itself. 
We must also be realistic, however, about the forces that make the above notions difficult to accomplish; it seems our economic system is on a collision course with the physical limitations of natural environmental systems, and our dependency on financial capital and income (for our livelihoods as well as for paying off loans), makes it unlikely that major change will occur without a crisis of significant proportions. That being said, such major changes will not be in the offing with this project, but rather a more moderate approach to change will be looked at.

Purposefully altering our natural surroundings is something we have done on this continent for the past 300 years. In southern New England, native Americans would selectively set large fires to clear woodlands for farming, creating the mosaic quality of some ecosystems; and when the colonists arrived from Europe, they began an assault on the land by cutting down the oldest trees for masts on sailing ships (Cronon 1983). Initially, there were reports of an overwhelming abundance of wildlife and vegetation, but with the continual clearing of forest, and hunting, by the end of the 18th century, wolf, deer, elk, bear and lynx had virtually disappeared; by the middle of the 19th century $3 / 4$ of Southern New England is estimated to have been deforested (Cronon 1983).

\section{Living Sustainably}

While once it seemed appropriate for humankind to "subdue" the earth, it is increasingly paramount to re-align our human actions back within the earth's ability to absorb these actions (Krueckeberg 1991, Chiras 1992, Daly and Cobb 1994). There is a hierarchical relationship that the human species has between planet Earth and itself: physics (of the physical planet) comes first, and ultimately. There is a physical limit to the biomass' ability to sustain the planet's species; and as we harm the biomass and the atmosphere as well, the ability to sustain the life of multiple species, including our own, is jeopardized (The biomass is the thin blanket of vegetation that covers the earth) (McHarg 1991). 
The notion of maintaining Earth's biomass capacity can be thought of as carrying capacity: the ability to support populations of species indefinitely (short of an astronomical calamity such as the expected death of our own sun). Sustainability, then, is the ability to live within the Earth's carrying capacity. (Chiras 1992, Meadows et al. 1992, Piel 1992, Postel 1994). This is expanded upon:

It is unlikely that there will ever be any global agreement on anything but sustainability of a level of welfare sufficient to satisfy very basic needs of survival. Hopefully, this would include sustainability of basic life-support ecosystems, biodiversity sufficient for robust ecosystems and future information needs, and sustainability of renewable resource systems at levels of regeneration sufficient to provide for substitution options to future generations (Farber 1991)

Currently, many citizens of the industrialized nations are expressing deep concern over issues dealing with the global environment. Since the advent of the atomic bomb, there has been a growing realization that humankind has not only "found" a way to alter the shape and patterns of the natural world, but has actually begun to do so on a scale heretofore unseen. Since the advent of Earth Day in 1970, there have been a number of International Summits to discuss the growing concerns, and to formulate agreements as to ways to deal with man's recent (and mostly negative) impact on the ecosystems of the world.

The concept, definition, and ensuing discussions of sustainability began in the 1970's. Broadly, sustainability means the ability to endure, and provides a perspective of both viewpoint and measurement as to where our planet is in terms of its natural resources, as well as the effects human activities are having worldwide. If environmental sustainability is the achievement of balance between the rates of resource use, resource depletion, waste disposal and resource renewal, in order to endure as a human species, then sustainable development is the human behavioral response required to achieve that sustainability. This response has been discussed as a developing environmental ethic, 
which includes norms, values, and principles that guide the appropriate relationship and actions between the human species and nature.

Sustainability requires the understanding of the physical world around us; it requires acceptance that many of our natural resources are finite, and knowledge that many of our renewable resources are being consumed at rates faster than replenishment. Environmental sustainability is the understanding that survival for our own species on the planet requires an understanding of the rates of resource use, resource depletion, waste disposal, and resource renewal. There needs to be acknowledgment that the rates at which we use the physical (natural) resources of the planet is unassailably higher than the rate at which they are being absorbed as wastes and/or replenished, and that many of our human activities are out of balance with natural processes.

\section{Steady-State Ecology}

In seeing the broad, holistic process of human life, we take raw materials, using the planet as an input source, turn them into goods using (other) materials and energy, and then output wastes and pollution back to the earth, using the planet as a "sink" (Meadows et al. 1992). Throughput is the rate at which the ability of sources can supply the needed materials and the sinks can adequately absorb the pollution and waste. Steady-state ecology is based on the need for a balance between input and output. A steady-state ecology is capable of growing only if throughput can remain balanced (Merchant 1992). This has ramifications for economic development as well as suburban sprawl, for "growth" of the human footprint has not been tied to natural forces since the beginning of the industrial revolution, and has far outrun the ability of natural processes to adapt. Pollution is one symptom of this.

\section{Carrying Capacity}

The term carrying capacity is a concept that relates to the size of population that can be permanently supported by the resource base. If we look at the need for the most 
primary survival resources of drinking water and food, it is thought that at most the planet could support 25 billion people (which would occur in only 80 years at current growth rates), but this population (including existing population) would have to live on a much lower caloric and protein intake than the industrialized world currently consumes, in order for everyone to be fed. Therefore current rates of food consumption, especially in industrialized countries, is not sustainable.

Fresh water provides another potent example of this lack of balance. In inhabited areas of the planet, of the net amount of water available for human use after runoff (projected for the year 2000 as 9,000 cubic kilometers) - only about 5,500 cubic kilometers is useable. Some 3,500 cubic kilometers are not useable due to pollution, which leaves the inhabited world with an excess of only about 2,000 cubic kilometers. If population grows as projected by the World Resources Institute, however, world populations in the 21 st Century will need to capture additional water with new dam projects, desalinization plants, and additional transportation networks to make up for additional demands (Meadows et al. 1992).

\section{Supporting Biodiversity \& "Wildness"}

By the late 1980's, prominent think tanks such as The Global Tomorrow Coalition began to realize that the cutting down of large amounts of tropical rain forests would have a substantial affect on the world's genetic resources, as well as adding to the accumulation of greenhouse gases in the Earth's atmosphere. When Our Common Future was produced by the World Commission on Environment and Development (UNCED 1987), the value of genetic resources was presented initially, and prominently, in terms of their economic benefit, producing billions of dollars annually for agricultural, medicine, and industrial sectors. Within a few years of Our Common Future, the need for preserving genetic diversity (now known as biological diversity, or simply: biodiversity) had broadened beyond economic values. Species, it is now acknowledged, are needed for our physical as 
well as economic survival, and should also be seen as deserving preservation for their own intrinsic values (Kellert and Wilson 1993, Grumbine 1994, Noss and Cooperrider 1994).

\section{Biodiversity}

In 1992, the United Nations convened the Earth Summit in Rio de Janiero, and biological diversity was discussed as one of the twenty-one key issues supporting sustainable development today and in the 21st Century. Chapter Fifteen of Agenda 21, the document that identifies and discusses these issues, deals with the conservation of biological diversity. The introduction of Chapter Fifteen starts off by stating that "the current decline in biodiversity is largely the result of human activity and represents a serious threat to human development". It goes on to say that "urgent and decisive action is needed to conserve and maintain genes, species, and ecosystems with a view to the sustainable management and use of biological resources" (UNCED 1992).

The end result of the Earth Summit regarding biodiversity was the signing by over 150 governments of the Convention On Biological Diversity. In the ratified document, the preamble states powerfully that a "fundamental requirement for the conservation of biological diversity is the in-situ conservation of ecosystems and natural habitats and the maintenance and recovery of viable populations of species in their natural surroundings" (UNCED 1992). The Rio Earth Summit, where over one-hundred and fifty governments from around the world spoke with one voice, gave birth to the legitimacy of biodiversity and its global importance.

Though it is not known what the minimal amount of species required for survival of the human race would be, it is known that the health of the Earth's ecosystems as well as human, animal, and plant species, is dependent on its biological diversity:

Species diversity - the world's available gene pool - is one of our planet's most important and irreplaceable resources....Without diversity, there can be no selection (either natural or artificial) for organisms adapted to a particular habitat that then undergoes 
change....No artificially selected genetic strain has...ever out-competed wild variants of the same species in the natural environment (Wilson 1989).

When organisms cannot adapt to changes occurring in their environment, they become extinct (Wilson 1989). Homo sapiens depend on other organisms (food, and medicines derived from plants) to survive. And since we are still part of the food-chain, harming or killing off of enough lower organisms will inevitably lead back to an effect on ourselves. In a recent article printed in the Boston Globe, coral reefs thousands of years old in the Florida Keys appear to be rapidly dying (the only such reefs in the continental United States), possibly from pollution from dumping of human sewage and farm chemicals (May 1997). Not to worry, you say?.... They're pretty to look at, but not all that important... Think again. According to the article, "though reefs cover less than one percent of the earth's surface, they are home to a quarter of all marine fish species". "For humans", the article concludes, "the destruction of reefs could hasten the collapse of fisheries by wiping out spawning and feeding grounds" (May 1997). Fish as a food provides almost 25 percent of all humanity's animal protein (Goldsmith, et al 1990).

Once organisms and their genes become extinct, they can never be brought back (Wilson 1989). As technologically capable and "efficient" as the human race has become, it is still totally impotent in creating an original gene. It has never occurred. All genetic improvements (alterations) have been made with existing genes (Wilson 1989, Gore 1992, Meadows et al. 1992, Piel 1992, Cherfas 1994).

A reduction of species, then, reduces the total gene pool. Though 50 percent of all the world's species is believed to (have) existed in the tropical rainforests (Wilson 1989, Meadows et al. 1992) the genes of plants and animals there are different from those in the temperate region of the world, such as the United States and Canada. In this country, the agribusiness method of planting monoculture crops has actually weakened crop genetic resistance to disease (Gore 1992). In fact, new strains of resistant crops (and seed) are 
only found in certain areas of the world, where they are allowed to grow wild and create their own genetic varieties through natural selection. Some of these locations are being destroyed, however to make way for hydroelectric dams, roads, and logging (Wilson 1989, Gore 1992).

Aren't all the zoos, national parks, worldwide natural preserves, and genetic plant banks which exist enough to preserve the minimum necessary biodiversity (biological/genetic diversity)? The answer at this time, is very likely 'no', because another factor to consider regarding species is that ultimately, the genetic health of individual species is dependent on a minimum population of not only that same species but a diverse mixture of interdependent species (Wilson 1989). That minimum population of species needs a minimum of land area for its habitat (Wilson 1989, Noss and Cooperrider 1994), and that habitat is being altered for human purposes. Though there is much discussion today about how many species are actually "needed", it is accepted that it takes a certain number of species for a habitat to become stabilized, and that genetic destabilization can occur below this threshold (Wilson 1989, Goldsmith et al. 1990, Marsh 1991, Croonquist 1993, Beatley 1994, Tillman et al. 1994). This threshold "extirpation" occurs at about 50 individuals, below which point species experience genetic mutations and eventual extinction (Wilson 1989). Extirpation, the gradual dying off of a species, occurs for larger ground-based animals as we destroy and fragment contiguous habitat, the living terrain where biodiversity occurs (Noss and Cooperrider 1994). .

\section{Habitat}

The criticality of preserving habitat to preserve biodiversity is a primary "thesis" for this project. Habitat consists of the natural surroundings where both flora and fauna can find the food, water, and shelter that they need, in an environment (climate and safety from other predators) that they can be or are adapted to (Morrison et al. 1992). The health of a species is directly related to the health of that species' habitat, high quality 
habitat leads to long-term survival and reproduction of the species that live there (Morrison et al. 1992).

Reduction of habitat is known to reduce the total number of species able to survive in that habitat. The quantity of species will be reduced by half, if 90 percent of the habitat is taken away (Wilson 1989). Habitat "islands", created when habitat is destroyed, alters biological processes and can lead to species extinction. Extinction due to this fragmentation is thought to have at least four causes: (1) exclusion of the species from the new "island"; (2) new habitat "islands" that are too small or no longer heterogeneous; (3) smaller, more isolated populations at greater risk from catastrophes or genetic deterioration or social dysfunction; and (4) disruption of important ecological relationships, such as the loss of a key (keystone) species (Morrison et al. 1992). Fragmentation, therefore, greatly affects species population, genetic richness, and the overall biological diversity of the ecosystem (Morrison et al. 1992).

\section{Wildlife Preserves and Corridors}

If we are to live sustainably, we must share land with wildlife, meaning being intentional about setting aside areas where wildlife can exist in natural habitats and be able to migrate to other areas. According to biologist Reed Noss, what is needed throughout the world's continents are networks of protected reserve areas the size of our National Parks, surrounded by two levels of buffered use zones, all connected by wildlife corridors (Noss and Cooperrider 1994). To allow enough territory for wolves, cougar, bears and other keystone species, up to 50 to 60 percent of the land mass would need to be set aside for wildlife (Noss and Cooperrider 1994, Trombulak 1996). Agreeing to an arrangement of this scale will take a major shift in our environmental awareness, and an environmental ethic much stronger than currently exists. Small-scaled wildlife corridors of 50 meters (164 ft.) to 200 meters (656 ft.) in width or more can be very beneficial for wildlife other than large vertebrates, however (Desbonnet et al. 1994). 


\section{Protection of Wildness}

How does the study of biodiversity speak to a sense of stewardship for the environment? Through recent theories such as the biophilia hypothesis and deep ecology, the need for, and the biological connection with the environment by human beings is being discussed and debated. Many argue that our experience with the land needs to be renewed if we are to understand why we need to preserve our ecosystems (Kellert and Wilson 1993, Berry 1995, Brower 1995). Deep ecology asserts that we need to connect ourselves back to the biological processes we have gotten away from in civilization, and in doing so reorient our thinking and our actions to a biological/sustainable timetable

According to Grumbine the word "wilderness" separates people from nature, and is somewhere "out there" needing to be tamed or conquered by people (1994). Wildness, in contrast is "the process and essence of nature....the source of resources and of human existence.... a place that we are adapted 'to', or live in harmony 'with'" (Grumbine 1994). Protecting wildness is done for the purpose of establishing a stronger connection to the ecology:

The ultimate purpose of protecting wildness is not to preserve nature or improve upon it, but rather to learn a sense of limits from it and to model culture after it. The strategy of protecting large wildlands with ecosystem management could slow the rate of the biodiversity crisis while also providing a model that could support the nature/culture system both ways - sustaining wildness at the core of protecting protected lands as well as at the center of human communities. The promise of this strategy is that as people begin to gain direct experience with ecosystems by working to protect biodiversity, wildness may explicitly become part of culture (Grumbine 1994)

\section{Biodiversity Planning in a Regional Context}

At a local scale, self-contained biological energy systems are called ecosystems, and an ecosystem's health and stamina are based primarily on: the diversity of its species of plants and animals; on the occurrence of keystone species; and on changes/threats to 
species habitats (Noss and Cooperrider 1994, Haueber 1996). Ecosytems provide a number of vital functions for our planet, including maintaining the quality of the atmosphere; control and amelioration of climate; regulation of freshwater supplies; generation and maintenance of soils; disposal of wastes and cycling of nutrients; pest and disease control; pollination; and direct supply of foods (Ehrlich and Ehrlich 1981).

When thinking about biodiversity and biological processes in terms of physical scale, we need to think regionally (Merchant 1992, Noss 1992). According to Noss (1992), there are four major levels of biological organization: genetic level; species level; community/ecosystem level; and landscape/regional level. Of these, the landscape/regional scale helps plan for the broad perspective of ecology, avoiding the narrow parochial thinking (of the species and genetic levels, for example) that can undermine appropriate consideration of the larger systems upon which the species and genetic levels depend. Not surprisingly, however, there is no regional plan available today for preserving biodiversity via wildlife corridors in Worcester County, Massachusetts; there are only maps of known rare and endangered wildlife habitats.

Thinking regionally about ecology is more in tune with the environment because the natural landscape doesn't exclusively follow political boundaries. Landscape features caused by the physiography of the land, such as mountains, hills, forests, rivers, streams, for example, occur throughout multiple jurisdictions; and various wildlife traverse back and forth across self-determined territories without concern for artificial boundaries. The northern Appalachian plain, formed by glaciation hundred of thousand of years ago, helps shape the particular microclimates in the New England region. Weather does not pay attention to political boundaries!

Until recently, we have considered ecological systems from a mostly static, "climax succession view"; now, we understand better that the environment works in a more dynamic type of equilibrium, and this has led to approaching the issues from a more systemic perspective (Haeuber 1996). 
Where treatment of common resources such as air and water from upwind, upstream communities can impact downwind and downstream communities unfairly, thinking regionally helps confront the "tragedy of the commons" issue (Hardin 1968), by having communities act more responsibly toward their neighbors. This raises ethical issues, which will need to be worked out.

\section{Thinking Bioregionally}

Locally, many people have long since forgotten, or indeed may have never known where their water supply comes from, or what birds migrate through their areas at different times of the year, or what historical geologic processes caused the local topography (Merchant 1992). To become more familiar with these processes people need to look at their land in bioregional sections:

'Bioregions are geographic areas having common characteristics of soil, watersheds, climate, and native plants and animals'...(but) beyond the geographical terrain is a terrain of consciousness - ideas that have developed over time about how to live in a given place. (Merchant 1992)

Being sensitive to the environment means getting to know it on a deeper level in order to know where we live. A bioregional "quiz" was written back in 1981 to help in such an effort; including such challenges and questions as:

- Trace the water you drink from precipitation to tap.

- What soil series are you standing on?

- What were the primary subsistence techniques of the culture that lived in your area before you?

- From where you're reading this, point North.

- Name 5 migratory and 5 resident birds in your area.

- When do the deer rut in your region, and where are the young born? (Charles et al. 1981)

\section{Watersheds}

One of the more prominent building blocks for bioregions has become the watershed (Haeuber 1996), important because one of the human cultural characteristics 
necessary for a bioregion is that it be "small enough for local residents to consider it home" (World Resources Institute 1992, emphasis in original). Outside of New York City, for example, the Westchester Land Trust has started a stewardship project to protect the Mianus Watershed from non-point source pollution. Called the Mianus Watershed Bioregional Planning Project, the goal is to educate individuals about the various components of their drainage basin, in the hopes that by understanding their own water supply, sewage flows, and the combined master plans of the various communities, sustainable use of resources may result (Wilson 1995). We need in Charlton to think about where our bioregion is, based on some geographical limit of our human community and our ecological systems, so that we can plan a sustainable future.

\section{Efficacy of Our Economic System}

An important acknowledgment to be made by this study is just how strong the capitalistic market forces are in shaping our major (and indeed every-day) economic decisions. Decisions to construct residential subdivisions are rarely, if ever set in motion by altruistic motives, but even if they do begin that way they are soon subjected to the requirements of capital finance providers. When push comes to shove, cash flows must be projected to remain positive over the life of a project to assure adequate financial return to financiers, and funded projects must provide assurance of adequate profit to developers for the risks they will incur. In these circumstances of development, where time is money and profits, and where future monetary capital is often the lifeblood of people's livelihoods, it is more difficult to be thoughtful regarding regional environmental impacts of a project.

Capitalism is unsustainable from the perspective of ecological requirements because capitalism requires "growth" as its motive force, and not stasis (O'Connor 1994). As a whole, the earth's natural resources are being consumed at rates exceeding their 
replenishment (Scientific American 1989, Goldsmith, et al.1990) which, by definition is a process that is not sustainable over the long term.

\section{Using Economics to Explain Environmental Issues}

Today, even as the long-term efficacy of the capitalism is questioned regarding the environment, scholars and thinktanks are using people's understanding of economics to explain the benefits and costs of protecting the environment. As one example, our macroeconomic accounting of Gross Domestic Product (GDP), and our individual corporate accounting systems do not take into consideration the costs of pollution, depletion, and degradation of natural resources back into the environment. If we are to bring ecology and economics together, it is thought that our economic system must reflect the ecological system under which it operates; to align ourselves with the natural world in which we are a part we would need an "environmental accounting system". Such a system would work as follows:

A frequent and practical suggestion for rectifying the deficiencies with the conventional economic accounts is to develop separate or "satellite" accounts that describe the flows of resources, materials (including pollutants), and energy that underlie any economic activity. These accounts display input-output balances that are necessary consequences of physical conservation laws. The accounts show an initial stock (or "opening balance") of a resource, its dimunition through use and degradation, its augmentation during discovery or, in the case of renewable resources, through natural growth, and, finally, the total stock at the end of the accounting period (or "closing balance"). Thus. in principle, such accounts show the depletion of natural resources but also their transformation into goods and materials, some of which may find their way back into the environment in the form of pollutants. The material or energy accounts can be linked to the conventional economic accounts through the use of ratios (or input-output coefficients) that express units of energy or material use per unit of production or sales. (Peskin 1990)

As another approach, the Contingent-Valuation-Method (CVM) is used to survey people on the value they would be willing to pay for an "environmental good" such as a 
new park or for being able to hunt in Maine (Brookshire and Mckee 1994). And at the Worldwatch Institute, an environmental think-tank in Washington DC, the services provided free by the environment, such as prevention of soil erosion, cleansing and recharge of the drinking water supply, the filtering of pollutants, the cleansing of our air, and the retention of carbon dioxide were recently given a value in economic terms to show how costly it would be to replicate the same functions with man-made systems. The value of nature's services reaches into the trillions of dollars (Abramovitz 1997, Costanza et al. 1997).

\section{Synthesis}

The broad problem we are faced today regarding the environment is that as a species, humans have now reached the critical mass necessary to not only physically alter the earth, but to cause change to the global climate as well. It is a climate that has no equal anywhere in our solar system; a climate that existing lifeforms are one-hundred percent dependent on for survival.

\section{Sustainability}

We are not living sustainably. The stocks of clean, raw resources are being taken out from the earth and used faster than they are being replenished, and retumed faster than they can be absorbed harmlessly back into the sinks of the planet: the soil, the water, and the air. The genetic stock from wildlife species is also being depleted rapidly by human intervention, and species extinction is happening faster now than at any time in history, save with the dying of the dinosaurs (Wilson 1992)

\section{Stewardship}

We have to start by caring for the future of the land for future generations. If they are to have what we have had (or perhaps better), we have to care for the land. Timothy Beatley recently echoed this thought about stewardship in his book Ethical Land Use: 
"The notion of land as a commodity, that is held temporarily and in trust for future generations, is an extremely appealing ethical concept. It helps establish the sometimes foreign idea that the use and ownership rights of future generations may create legitimate moral constraints on the use and ownership rights of the current generation". (1994, emphasis in original). Beatley also mentions the thoughts of Edith Brown Weiss regarding her three "principles of intergenerational equity": "(1) each generation must protect the diversity of the natural and cultural resource base (the 'conservation of options' principle); (2) each generation must pass along the planet in no worse condition and each generation is entitled to an equal level of environmental quality (the 'conservation of equality' principle); and (3) each generation must ensure all members equitable access to the planetary legacy (the 'conservation of access' principle)" (1994).

\section{Biodiversity}

If maintaining biodiversity is valid because it properly supports sustainability, then we must learn what is needed to support biodiversity and work to preserve those things. The preservation and conservation of wildlife diversity (the diversity of both flora and fauna) requires saving the natural land area, soil, geology, vegetation, and wetlands that wildlife depend on for their survival (Benyus 1989). Incorporating into subdivision design contiguous, open-space areas that function as habitat areas and corridors for wildlife is the primary goal of this project. 


\section{Ch. 4}

\section{Concepts To Consider:}

\section{Designing "Connection" into Open-Space Subdivisions}

Charlton's "Flexible Development" subdivision option is not as well thought out as it might be for either people or wildlife; instead it allows the developer to cut costs without giving a more beneficial design in return. Open space "islands" are being created that have limited connectivity with one another, making them little more than buffers of undisturbed land between developments. While these buffers are somewhat useful from an aesthetic perspective, better regulations and design guidelines would be helpful in creating more useable "corridors" for wildlife and trails for people, which in return will help to preserve wildlife biodiversity and provide meaningful recreational opportunities for residents. As discussed earlier in this study, fragmentation of contiguous wildlife habitat is a major cause of declining wildlife species. Continuing along with the status-quo would perpetuate inefficient stewardship of natural resources, and continue the building of subdivisions where people are separated from nature.

The overall problem of "disconnection" also has an additional human dimension. Though road width, lot sizes and frontages have been greatly reduced in Charlton for flexible developments, the resulting human settlement is still akin to "sprawling pods" of unrelated units; less a setting for a community of people than a "photographic backdrop" for each individual structure. The human scale, in short, continues to be undermined because front setbacks and porches (if they exist at all) in current flexible development subdivisions tend to be too far back from the sidewalk or the road, as they have been in Charlton's conventional subdivisions. Lot widths are also still too wide, especially in culde-sac areas, which are appropriate settings for intimate neighborhoods. 
These points, as mentioned here and previously, have helped frame the overall "problem" of this study. In this chapter an integrated methodology is discussed for making improvements in our stewardship of biodiversity, for connecting with our natural surroundings, and for enhancing our human community.

\section{Integrating the Parcel Into The Larger Ecological Landscape}

Intuitively, we know that water is needed for life to exist on the planet, and that fresh water is important in our everyday lives. Fresh water for drinking has become another packageable commodity, however; many of us spend money on "clean" bottled water from Poland Springs, Maine, or from the Adirondack Mountains in New York, water that in actuality comes from natural rivers and streams. Only these particular mountain rivers and streams are away from many of us city folk, who think that the water is always cleaner away from home.

Getting to know our own local watershed's various riparian areas: the streams, ponds, lakes and woodlands, is the first major step in relating to our natural environmental surroundings. Touched on earlier, the local watershed is part of a larger bioregion. Water does not come from Stop \& Shop, it is actually a finite resource that is constantly recycled through the hydrological process of precipitation, surface runoff, percolation, evaporation, transpiration groundwater flow, and vapor transport through clouds (Mauritus la Rivière 1989). The water we drink today is the same water our ancestors drank (Lamb 1990), albeit a bit more processed. Even with all the processing, as long as it rains it will go through the same cycle; and as long as there is enough contiguous, natural land remaining, this cycle can support (up to its carrying capacity) human life and wildlife.

The question that's asked with this first step is: regarding the local watershed, are there any nearby perennial streams either on site or within 200 meters (Desbonnet et. al 1994) of the site boundary? Riparian forests and vegetated buffer areas within this range 
serve important environmental and ecological functions such as pollution removal, flood control, wildlife habitat and wildlife movement corridors; they should be given high consideration on the proposed project site as areas not to be developed (Croonquist and Brooks 1993, Desbonnet et. al 1994, Noss and Cooperrider 1994, Blankenship 1996).

Secondly, the local watershed should be considered in the regional/landscape context of its entire drainage area, to include physiography, vegetation, and climate (Pease 1995). Taking this regional/landscape approach can inform decisions regarding the preservation of biodiversity through a network of interconnected reserves. Looking at perennial streams in the entire drainage basin with overlays of estimated rare or threatened wildlife habitat and areas of contiguous forest, as an example, can point to the design of regional wildlife corridors and wildlife reserves (Noss and Cooperrider 1994).

\section{Understanding Ecological Regulatory Mechanisms}

The State of Massachusetts has several regulatory mechanisms that can provide support for the design of open space conservation subdivisions. Three will be discussed in this section: the Wetlands Protection Act, the Rivers Protection Act, and Forest Cutting Practice Regulations. When used together, these tools can provide the legal "teeth" to design local and regional wildlife riparian corridors surrounded by contiguous wildlife habitat, thereby improving the chances of maintaining area biodiversity.

\section{The Wetlands Protection Act}

Established in Massachusetts under the requirements of the federal Clean Water Act, municipal conservation commissions have jurisdiction over areas within 100 feet of wetland resources. Wetland resource areas can be swamps or meadows bordering on the ocean, estuaries, coastal wetlands, beaches, dunes, flats freshwater wetlands, banks, rivers, streams, ponds or lakes; or any land subject to tidal action, coastal storm flowage or flooding; or land under said waters. They are also further defined by species of vegetation 
or proximity to moving/standing water in the Annotated Laws of Massachusetts (ALM) (Ch.131 § 40).

If any portion of a proposed project falls within this 100 foot "buffer zone", the conservation commission must determine if the area on which any dredging, filling, removing or altering is to be done "is significant to the public or private water supply, to the groundwater supply, to flood control, to storm damage protection, to prevention of pollution, to protection of land containing fisheries, to the protection of wildlife habitat, or the protection of fisheries" (ALM Ch.131 $\$ 40$ ). If the determination is made that work in one or more of the resource areas impacts one or more of the eight areas of interest, then the conservation commission is to issue an "order of conditions" that will contribute to the protection of the affected interest(s) (ALM Ch.131 §40).

\section{Wildlife Habitat}

Precisely what constitutes important wildlife habitat under the Wetlands Protection Act (the Act) has been given close scrutiny in an appendix of the regulation, and is not accorded the presumption of importance to the protection of resource areas as the other seven interests are. Primarily, the Act is only meant to protect this resource area if it provides important wildlife habitat functions such as food, shelter, migratory or overwintering areas, or breeding areas within the wetland resource area in question. This point is summarized in the Code of Massachusetts Regulations (CMR):

\footnotetext{
Thus while resource areas are presumed to be significant to the protection of other interests whenever they play a role in protecting the interest, a particular site must play a role in providing important wildlife habitat functions, and must do so because of the presence of specific physical habitat characteristics, in order to warrant a presumption of significance under the new wildlife regulations.
}

(310 CMR 10.00 Appendix: Preface To Wetlands Regulations Relative To Protection Of Wildlife Habitat: 1987 Provisions) (emphasis added) 
Using the Wetlands Protection Act exclusively to protect "wildlife habitat" as a resource area appears problematic, as each site has to be looked at on a case-by-case basis, and the required "proof" of habitat significance has to be made to meet the requirement. The results, at best would still produce a patchwork of individual habitat islands, which may or may not be contiguous or large enough to prevent genetic inbreeding depressions in wildlife, and eventual species extirpation (Ehrlich and Ehrlich 1981, Wilson 1992, Kim and Weaver 1994).

The Act is still a powerful tool, however, to protect individual wetland resources that help with flood control or prevention of pollution, as examples, because these same areas (such as forested rivers and streams) are also good wildlife habitats. These protected areas can act as core reserves within a larger, more contiguously preserved buffer area, which needs to be preserved by another means. This can be accomplished with forest cutting regulations, tree conservation ordinances, and with open space development regulations, which will all be discussed later in this study.

The biodiversity preservation model just described consists of core reserve areas, surrounded by buffer areas. These two components need to be tied together with a third element: wildlife corridors (Noss and Cooperrider 1994). As we will see in the next section, the basis for these corridors has been legally established in Massachusetts with the Rivers Protection Act.

\section{The Rivers Protection Act}

Passed into law in August 1996, the Rivers Protection Act is designed to work along with the Wetlands Protection Act, by adding a new resource area known as the Riverfront Area, 200 feet wide, to each side of a perennial stream or river. The purposes served by protecting the riverfront area are identical to the eight interest identified in the Wetlands Protection Act. 
Applicants proposing work in the riverfont area must now obtain an "Order of Conditions" from the conservation commission, using the same procedures specified in the Wetlands Protection Act regulations, demonstrating that the proposed project meets each of the two requisite performance standards identified in the statute. The applicant must prove by a preponderance of the evidence that:

(1) such work, including proposed mitigation measures will have no significant adverse impact on the riverfront area for the following purposes: to protect the public or private water supply; to protect the groundwater; to provide flood control; to prevent storm damage; to prevent pollution; to protect land containing shellfish; to protect wildlife habitat; and to protect the fisheries; and

(2) there is no practicable and substantially equivalent economic alternative to the proposed project with less adverse effects on such purposes.

(Massachusetts Association of Conservation Commissions Newsletter. Late Fall 1996) (emphasis in original)

Provided that no practicable alternatives exist to developing the project either on a different part of the site or on a different site altogether (extensive guidelines are provided by the Massachusetts Department of Environmental Protection for identifying practicable alternatives), the next hurdle in the statute is showing that no significant adverse impacts will occur in the riverfront area. Again, the Department of Environmental Protection has provided 5 criteria to local conservation commissions for making a "no-adverse-impact" determination for a project (all five criteria must be met):

(i) the work conforms to the performance standards for all other resource areas within the riverfront area;

(ii) an inner riparian zone of 100 feet of undisturbed vegetation .... measured horizontally from the river's mean annual high-water line is provided:

(iii) within the 100-foot outer riparian zone (beyond the inner riparian zone of undisturbed vegetation), alteration of riverfront area is limited to 5.000 square feet. or $20 \%$ of this 100 -foot zone, whichever is greater;

(iv) stormwater is managed according to a policy established by the Department: and

(v) no project may be permitted which will have any adverse effect on specified habitat sites of rare wetland or upland, vertebrate or invertebrate species, as identified by the 
procedures established under $310 \mathrm{CMR} 10.59$ or 10.37 , or which will have any adverse effect on certified vernal pool habitat.

(Massachusetts Dept. of Environmental Protection: memo entitled: Guidance for Implementation of the Rivers Protection Act Amendments to the Wetlands Protection Act. November, 1996)

The ramifications of the Rivers Protection Act (the Act) are that no disturbance of vegetation within 100 feet of a perennial river or stream is allowed for new projects, and a maximum of 20 percent of the area known as the outer riparian zone (between 100 feet and 200 feet away from the river or stream ) can be altered on a given parcel. The Act puts some powerful "teeth" into the creation of a $400+$ foot wide wildlife habitat corridor along perennial waterways, and should be utilized to its fullest extent in the creation of open-space subdivisions in Charlton.

\section{Forest-Cutting Practices Act + Tree Conservation Bylaws}

What if a proposed subdivision parcel is not located near a perennial stream or river, or consists substantially of upland? Massachusetts regulations regarding forestcutting practices combined with a locally created tree-conservation bylaw can help prevent the total denuding of a wooded site by a subdivision developer.

Forest Land is defined in Massachusetts Forest Cutting Practices as "land with at least $15 \%$ of the area occupied by the crowns of forest trees of any size that contains at least 7.5 square feet of basal area per acre; or that is a plantation containing at least 500 trees per acre; or land recently harvested that is in the process of regeneration." (304 CMR 11.03: Definitions). The regulation states that all land devoted to forest growth (which is defined as all forest land), is subject to the statute: Massachusetts General Law Chapter 132, sections 40 through 46 (Establishment of the State Forestry Committee).

While the regulation does state that: "clearing [of] lands for the purpose of changing land use, such as the creation of a houselot, a subdivision, or for mining gravel, or for any other activity requiring town or city permits" is exempt from the statute, it 
provides that they are considered exempt only when supported by the issuance of necessary permits prior to the start of cutting (304 CMR 11.02: Statement of Jurisdiction). This clause presents an opportunity for a municipality to regulate the cutting down of forests in its community; by implementing the requirements of a local tree-conservation bylaw in the project permitting process.

\section{Tree Conservation Bylaws/Ordinances}

With the awareness level rising about the importance of trees in the environment, a number of municipalities in the nation have instituted regulations regarding the cutting and/or planting of trees during the development process, sometimes incorporating them within a landscaping bylaw, sometimes creating them in a stand-alone fashion. These bylaws typically limit the percentage of existing trees that can be removed from a parcel and/or create provisions for replacing any trees removed with a slightly higher ratio of new plantings (Duerksen 1993). An example of a very basic tree conservation ordinance that would support the goals of preserving contiguous forested open-space with providing connection for people would be to replace 1.2 trees for every one tree removed during the development process, to be planted as in-fill for any afforested areas of the site (under the tree warden's direction), and planted as street trees along the public ways.

In Massachusetts, state enabling legislation exists for the creation of such a bylaw via Statute 1975, Chapter 808 , Section 2 a, which enunciates some of the purposes and objectives of zoning (Chapter 808 establishes the Zoning Act: Massachusetts General Law (MGL) Ch.40A). Section 2A specifically lists eleven purposes/objectives of zoning regulations, one of which reads: "to conserve the value of land and buildings, including the conservation of natural resources and the prevention of blight and pollution of the environment".

With establishment of its legal viability, a tree conservation bylaw would serve to limit the amount of trees that could be cut in a given subdivision development. In Charlton, with very little public sewer at this time, the bylaw would have to be written to 
reasonably accommodate primary and alternate areas for septic system designs, which likely means large, open backyards. Massachusetts septic system regulations now allow for common systems, which would help to minimize the total land-clearing requirement. This design may not be too difficult to accomplish in Charlton, since most flexible developments, when they are established, have common open space owned by the development's association. The Planning Board, however, would need to make some changes in its current regulations to take advantage of this type of design in future Flexible Development Subdivisions.

\section{Mapping Site Ecological, Visual, and HistoricalAttributes}

Site planning involves at its basic level a first step that maps the areas of interest/concern where they either do or could exist on a given parcel, then a second step of analyzing what these various characteristics mean to the placement of buildings, structures, roads, parks, views, etc.. The third step, the most difficult, would involve taking all this information and making judgments about which areas within the parcel to develop upon for people, and which to conserve for biodiversity, aiming for a result of balancing development values with conservation values (Steiner 1991, McHarg 1991, Arendt 1996).

In designing subdivisions for conservation of open-space, Randall Arendt, in Conservation Design for Subdivisions (1996), suggests 10 such areas to analyze on a given parcel in terms of development and conservation. If we take these 10 areas, and group them into compatible values (McHarg 1991), we can then analyze a given parcel for where development and conservation are to occur. Taking these ten areas and organizing them into a group of four values, we have: soils and aquifers/recharge areas for important environmental values $(1,2)$; wetlands, floodplains and slopes to determine where development should not be permitted $(3,4,5)$; significant wildlife habitats, woodlands and 
prime farmland as areas with strong ecological values $(6,7,8)$; historic/cultural/archaeological features, and views into/out of the site as valuable social features $(9,10)$.

One of the major concerns with only looking at the site itself is that it misses the larger, bioregional perspective that has been identified as a critical aspect to preserving biodiversity (Noss and Cooperrider 1994). Tying in the local with the regional scale of biodiversity preservation, the protection of smaller scale biodiversity could be handled by the creation of wildlife habitat corridors, a wooded buffer area surrounding a core of natural stream and/or river corridors. This concept is supported in Noss and Cooperrider, where many buffer zones and corridor areas proposed to preserve biodiversity in Florida run along the river system (1994). The goal of leaving contiguous areas of wooded openspace around a perennial stream in order to create a wildlife corridor would be missed if, for example, there's a stream just to the west of a new subdivision development, and house lots instead of open-space are being put on that same side.

An analysis should be done of the land at least 200 meters (Desbonnet et. al 1994) beyond the site's boundaries so that existing forested land and/or perennial streams and other ecological values can be identified that would suggest a potential wildlife corridor. Recent aerial photographs, field work, and USGS maps would provide valuable information regarding these.

\section{How Much Open-Space, and Where In the Subdivision?}

Conservation Biologists have estimated that perhaps 40 to 75 percent of land area on the continent needs to be kept in its natural state to preserve biological diversity (Noss and Cooperrider 1994, Povilitis 1995). These are sizable percentages, but they are based on the need to preserve larger carnivore species, as well as natural disturbance regimes (such as fire, flood, and wind damage) (Noss and Cooperrider 1994). Carnivore species 
are especially important to ecosystems, because as "keystone species" their presence helps maintain the natural balance of species populations. Conversely, their absence causes an imbalance among remaining species (Noss and Cooperrider 1994).

Preserving such large percentages of land as open space may not make sense in areas where habitat will not likely support wildlife. Preserving biodiversity where it is found, however, is a recent theoretical approach (UNCED 1992, Noss and Cooperrider 1994) to the problems inherent in saving species on a singular basis. Larger percentages of contiguous open space should be left intact where the landscape is most suitable.

Working on the premise of having a project site where habitat is suitable for supporting biodiversity, we might aim at preserving a minimum of 50 percent of the site as open-space (Arendt 1996), having 40 percent of that be maintained in its fully natural state (Povilitis 1995), and 10 percent be allocated to semi-natural open-space, useable for commons, visual relief, and/or active recreation. This would leave the remaining half of the land available for roads, pathways, and housing areas.

\section{Where To Locate Open Space}

Another consideration is how the open space to be left in its natural state is oriented with the housing and the external subdivision boundary lines. To be better useful to wildlife most of the open space needs to be located around the outside of the parcel, with the housing in the middle. There are a multitude of variations on this theme, of course, but the primary purpose of such a configuration is to preserve as much contiguous, undisturbed open-space as possible, both on-site and with adjacent properties.

Fragmentation of wildlife habitat as previously discussed can create separate islands of vegetation that cannot be traversed by many land-based species; too many separate patches of open space creates a large length and area of vegetation "edge". Called edge-effect, too much of it increases the rate of predation (being preyed upon), as well as increased susceptibility to parasitism for some species (Noss and Cooperrider 
1994), and also alters the microclimate of the wooded area (Noss and Cooperrider 1994, Blankenship 1996).

\section{Where in the Community}

If subdivision parcels are located in areas without much existing vegetation, or adjacent to land that is without much vegetation, the "creation" of new open-space through afforestation may not be as appropriate as preserving the contiguous areas of woodlands and forests that do exist, because wildlife habitat is already established. It may be important, therefore, to identify areas in the community where the creation of open space subdivisions would be a requirement, areas that are near perennial streams or rivers, or areas that are of important environmental, cultural, or aesthetic concern to the entire community. In Charlton, where almost 80 percent of the community is still forested it cannot be assumed that these areas will remain this way forever. Appropriate planning today is the only way to ensure that biological diversity will be minimally preserved for future generations.

\section{Active Open Space}

Active open-space used for common areas, such as play areas, ball fields, mailboxes, gazebos and gardens, etc. (Jarvis 1993), should be interspersed among the housing units, to provide pleasant views and community connection points. In a 20 acre parcel the 10 percent guideline would allow 2 acres to be used in this manner, not a very large area, but certainly not inconsequential. The average size of a town common/ town green in New England is two acres (Arendt 1994).

\section{Connection "Elements" Within Subdivisions}

Caring for our environment means being part of our environment, and physical access to nearby woods, streams, parks, and neighbors is what provides us with that connection. These elements include nature trails, pathways, sidewalks, shoulders and 
roads. Other amenities, such as landscaped garden areas, park benches, gazebos, mailboxkiosks, etc., can also help to provide a "sense of place" within a community (Jarvis 1993).

Having these corridors and "points" of connection is important; having a sense of human scale among these elements is just as critical. The distances that front doors and porches are from the street, the width of the road, the location of trees, the walkability of streets, streetlighting, and particular patterns of clustering homes, as examples, relate to our sense of appropriate proportion, to what size and distances our connections with our surroundings and with one another are to be. Some of these connections will now be explored.

\section{Open Space Access and Nature Trails}

Walking through the woods is a favorite pastime for many of us, a way to get back in touch with nature, to relax, and have some quiet time. Nature is not just someplace "out there", it not only exists in our own backyards, it should be explored and explorable (Noss and Cooperrider 1994, Berry 1995, Brower 1995). With the preservation of wooded open-space in a development, connection to this area should be actively encouraged through findable trail access points, and appropriately marked and useable nature trails.

Access points should be marked with signage that blends well into the surrounding area, yet stands out enough to be found; the National Recreation and Park Association provides a good background on this (Fogg 1990).

For towns that don't have the infrastructure for water mains and fire hydrants, fire protection ponds, or fire ponds as they are sometimes called offer a good opportunity as an entry point to a nature trail, as they often will extend back far enough to get to the preserved open space. Where fire ponds do not exist, appropriately marked easement paths should be designated, so that people feel comfortable walking through the back areas of the development. 
Nature trails should also be selectively cleared and marked in accordance with established guidelines. As an example, the National Recreation and Park Planning Guidelines book recommends a cleared path of 4 to 8 feet (Fogg 1990). Trails should also be designed to take advantage of any available views, interesting terrain, and interesting natural features; and they should be adequately marked with signage/markers at heights visible to most trail users.

\section{Common Areas}

It has been recommended previously in this study that about 10 percent of the open-space area in a subdivision parcel be devoted to active open space. Studies and experience have shown that home buyers will pay higher prices for homes that look out onto created open-space such as landscaped commons and golf courses (Arendt 1994). Volleyball courts, basketball courts, covered mailboxes, playgrounds and picnic/barbecue areas can also serve as community amenities, connection points and serene vistas which can be enjoyed and shared by all.

In a conventional subdivision these areas are not normally found, because maintenance of such common areas (including the streets, drainage, street trees, etc.) would eventually be turned over to the town, and the townspeople would not want to be responsible for the added costs involved if they could not derive the benefit of these amenities. Mentioned previously, home owner associations would be needed to care for these amenities, since the benefits derived would go chiefly to those that lived in the development.

\section{Septic Systems}

Common absorption fields, known as large scale absorption (LSA) systems should be considered as the primary design alternative for septic systems in communities (or individual open-space development projects) that don't have public sewer systems. Supported now in the Massachusetts Title V Regulations (which covers septic systems), 
they are designed so that individual septic tanks exist for each home, but effluent is pumped to a large, common area absorption field owned by a homeowner's association.

If LSA's are utilized, the required size of an individual parcel can be reduced significantly, and the extra area can go to the common absorption field, making a sizable town common, and adding to the total percentage of open space within the development. This absorption area (or areas) will come under the responsibility of the home owner association; its location should be established on the best soils of the subdivision parcel.

\section{Streetscapes, Roadways, and Lot Layouts}

Much of our sense of community and our connection to others comes from how our homes are arranged and related to our streets and to each other. This sense of human scale and connection has a number of components:

- The width of the street/road can determine how fast we drive or whether it is considered a boulevard or shared amenity for walking and playing. Suggested right of way width is 40 - 50 feet, with a 20-foot wide roadway (Jarvis 1993).

- Distances from door-step to door-step across the street, or distance from one's front porch (if there is one) to the edge of the street can determine whether people get to know their neighbors or whether they remain strangers who happen to live nearby. Suggested distance of front porch to front porch is 75 feet to 100 feet (Arendt 1994); and front porch to edge of street no more than 30 feet deep. Minimum side yard setbacks need only be 10 to 15 feet wide to maintain privacy when appropriate landscaping is utilized (Arendt 1994).

- The intentional establishment of street trees and sidewalks or shoulders as public areas can determine whether children and adults will comfortably ride or walk around their developments. Established trees should remain whenever possible, and shoulders with swales for stormwater drainage will help to maintain a more rural appearance. 
See the figure below for a sense of these concepts:

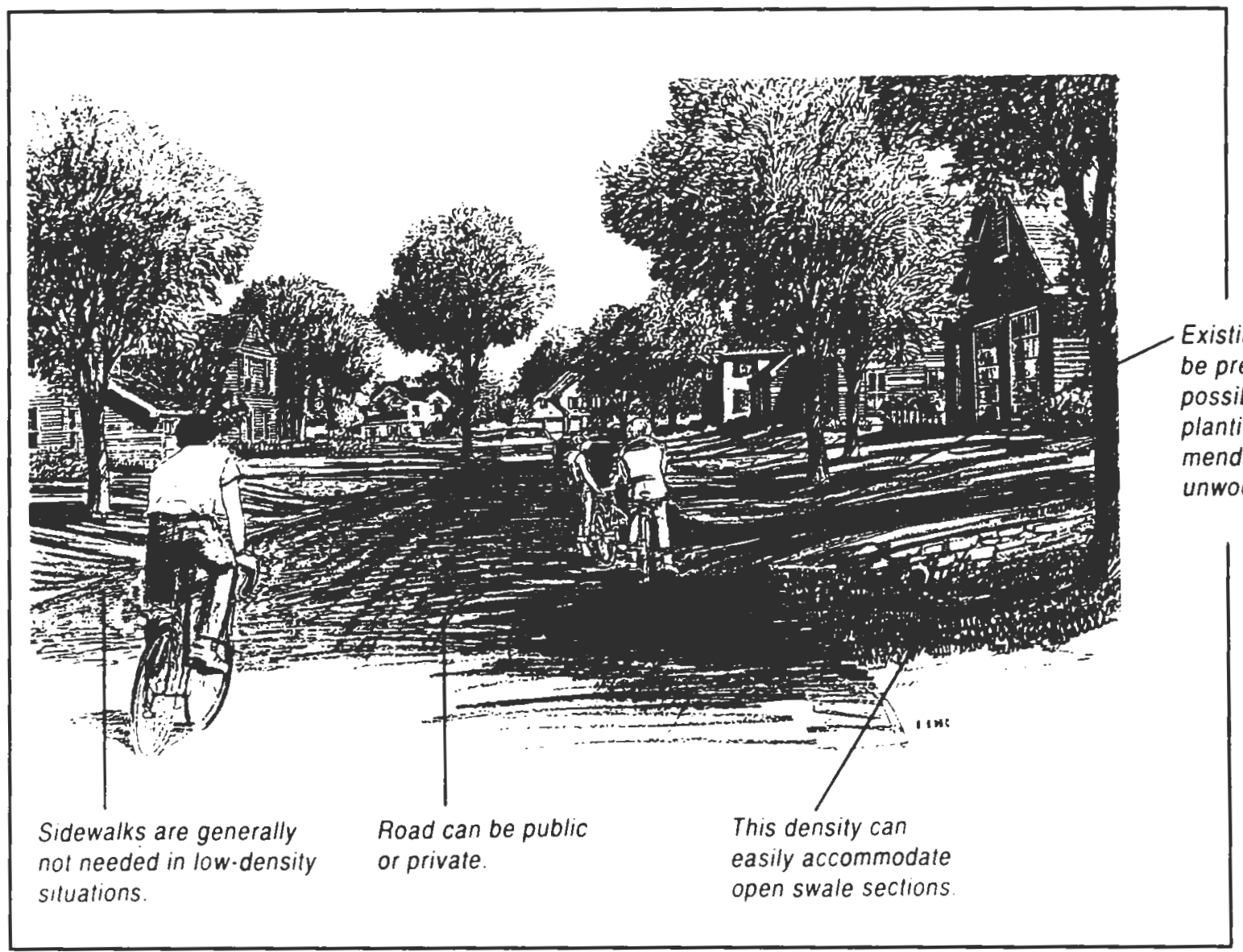

Source: Site Planning and Design for Great Neighborhoods, by Frederick Jarvis, 1993.

\section{Figure 4-1 Overall Streetscape Concepts}

The configuration of houselots in a development can also determine whether a community is characterless or colorful, isolated or charming. Multiple configurations within a development are encouraged to create an interesting juxtaposition of spaces; these should be tied together with a common element, such as signage or landscaping. Two common patterns and two creative, space-saving patterns are now covered: 
- Two of the more common arrangements: double-loaded streets with lots on both sides; and single-loaded streets with lots facing a common area are shown below:

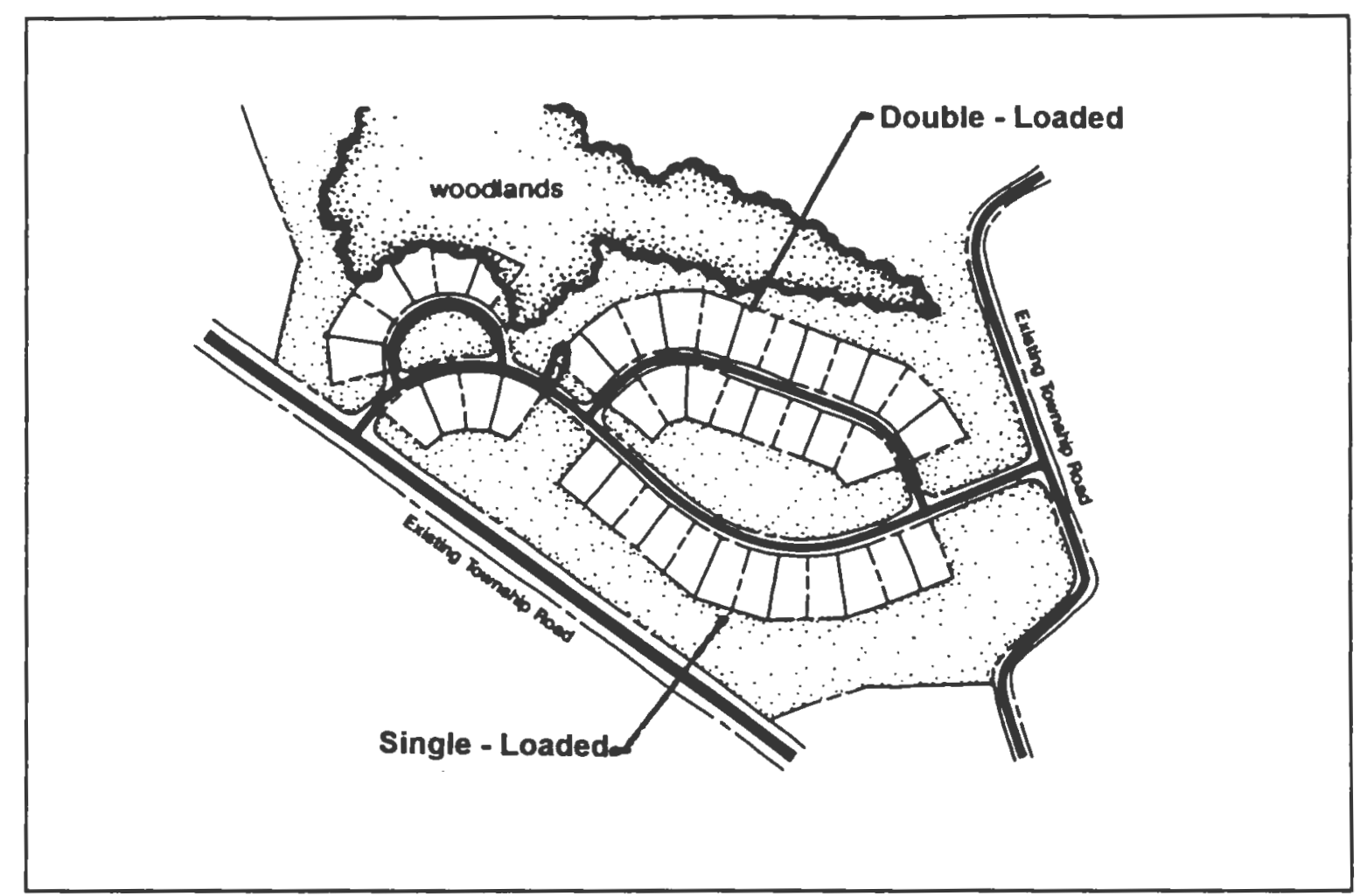

Source: Adapted from Conservation Design for Subdivisions, by Randall Arentt, 1996.

Figure 4-2 Single-Loaded + Double-Loaded Streets

- Two of the more creative arrangements for cul-de-sacs, one that allows more lots around it, and one that puts a center island (that can potentially be used as a common area for an LSA septic absorption system), are shown on the next page: 


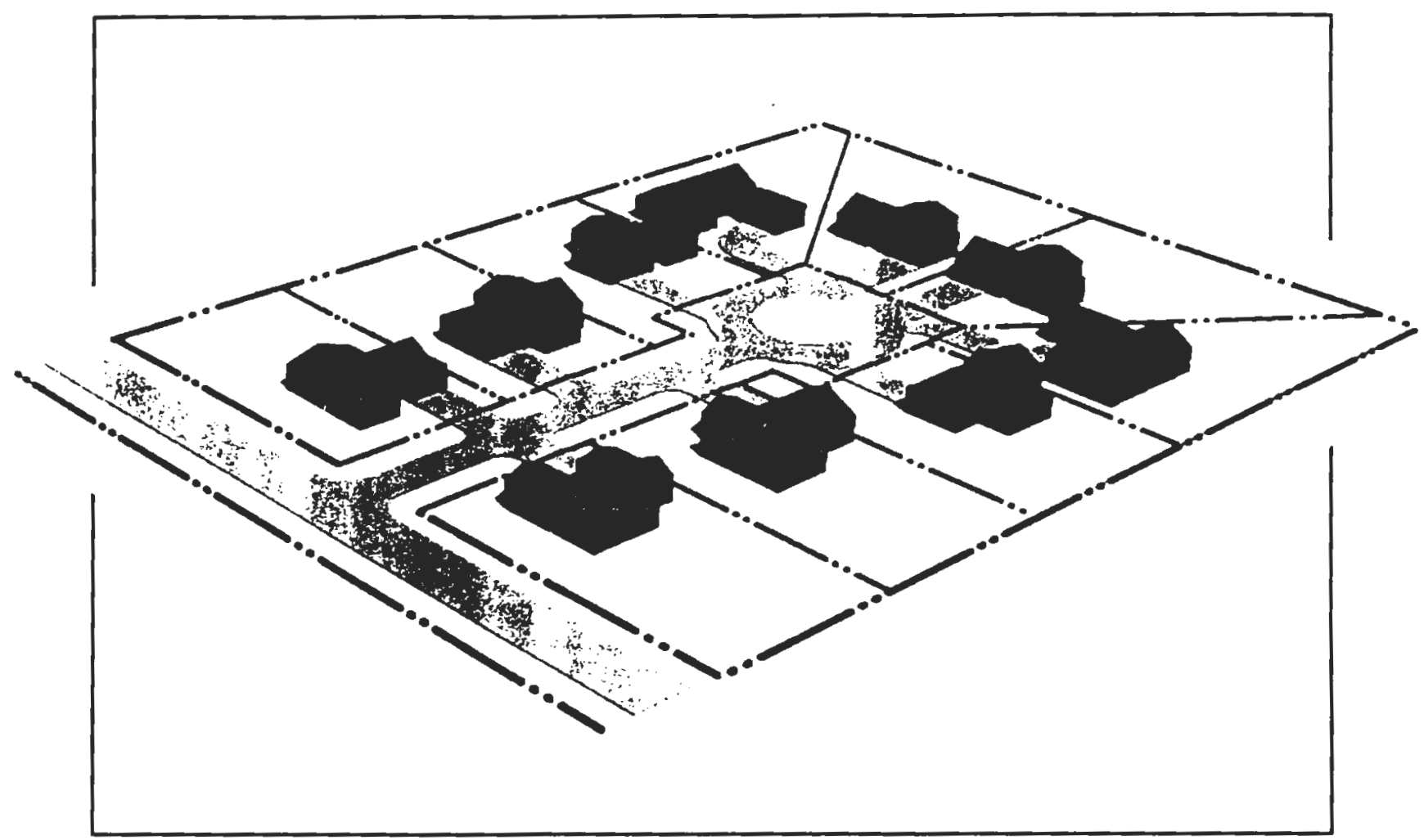

(a) Source: Site Planning and Design for Great Neighborhoods, by Frederick Jarvis, 1993.

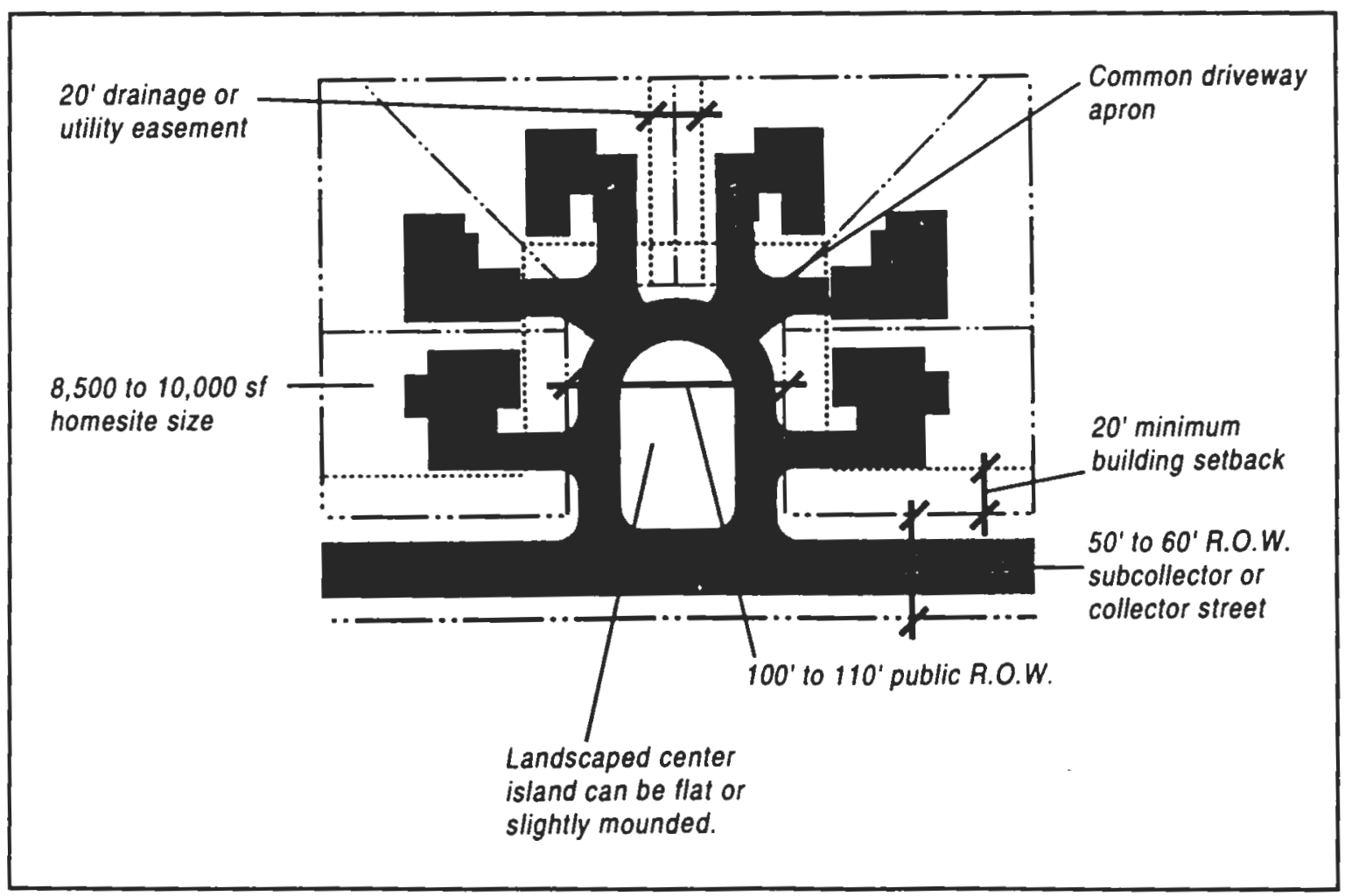

(b) Source: Site Planning and Design for Great Neighborhoods, by Frederick Jarvis, 1993.

Figure 4-3 (a, b) Space-Saving Cul-de-Sac Designs with Landscaped Islands 


\section{Synthesis: Steps to Lay Out Open-Space Subdivisions}

We have now arrived at the point in the study where all paths converge into the essence of the matter; where all disparate pieces of the puzzle are put together to discern the method for dealing with the initial problem. Connection: connection with nature and connection with others. Preservation of biodiversity, or at least a serious attempt at preserving biodiversity; and living more sustainably both with our own habitat and that of nearby wildlife.

There are two phases to this method: the first, Analysis, takes a look at the context of the specific subdivision parcel as it compares to off-site and on-site environmental, ecological, and social values. Phase two, Design, involves the physical layout of conservation areas, active open-space, house sites, street alignments and trails, and finally the house lot lines themselves (Arendt 1996).

Using an adaptation of Ian Mcharg's overlay method (1991) for phase one, we can determine areas of the site where development is to be avoided, and what areas of the remaining development should be highlighted, worked around, and/or taken advantage of to create a pleasant quality of life in the development. This phase has 5 parts:

\section{ANALYSIS}

- Analysis of the off-site ecological landscape:

- Is parcel near areas of critical ecological concern (within 200 yards)?

- Is parcel within 200 yards of a perennial stream, river?

- Is parcel within 200 yds.of existing trails, water bodies, cultural areas?

- Mapping and Analysis of On-Site Unbuildable Areas:

- Location of steep slopes over $25 \%$.

- Location of floodplain.

- Mapping and Analysis of on-site environmental values:

- Location of best, satisfactory, and poor soil areas for septic systems. 
- Location of any known/potential aquifer areas.

- Mapping and Analysis of on-site ecological values:

- Location of important/significant wildlife habitats.

- Location of contiguous woodlands/forest.

- Location of prime farmland.

- Mapping and Analysis of on-site social values:

- Location of any historic, cultural, or archeological features.

- Location of scenic views into/out of the parcel.

Using a composite overlay of the individual layers from phase one as its base map, phase two involves designing the layout of the subdivision's major elements. Prior to the following steps, however, we first need to know the actual number of lots that could be built on the parcel as a conventional subdivision. Known as a "yield plan", this important document needs to be required of the developer so that the number of lots allowed in the open-space subdivision is either the same as in the conventional plan, or somewhat higher as an incentive to provide extra amenities in the project. An incentive bonus could be adopted, for example, that allows additional housing units so long as the amount of open space is not less than 50 percent of the parcel. Alternatively, a direct percentage increase of 10 percent or 20 percent more units could be allowed. Knowing the number of lots we are aiming for (after having produced a yield plan), the design phase can begin:

\section{DESIGN}

- Layout of conservation areas:

Allowing initially for between one-half to two-thirds of the parcel as conservation area (Arendt 1996), highlight/encircle where the following exist:

1) land nearby adjacent streams, trails;

2) areas of critical ecological concern; 
3) contiguous woodlands;

4) unbuildable land: wetlands, flood plains, steep slopes (over 25 percent);

5) prime farmland;

6) most important views into/out from site; and

7) most important historic, cultural, and archeological features.

See diagram below for an example:

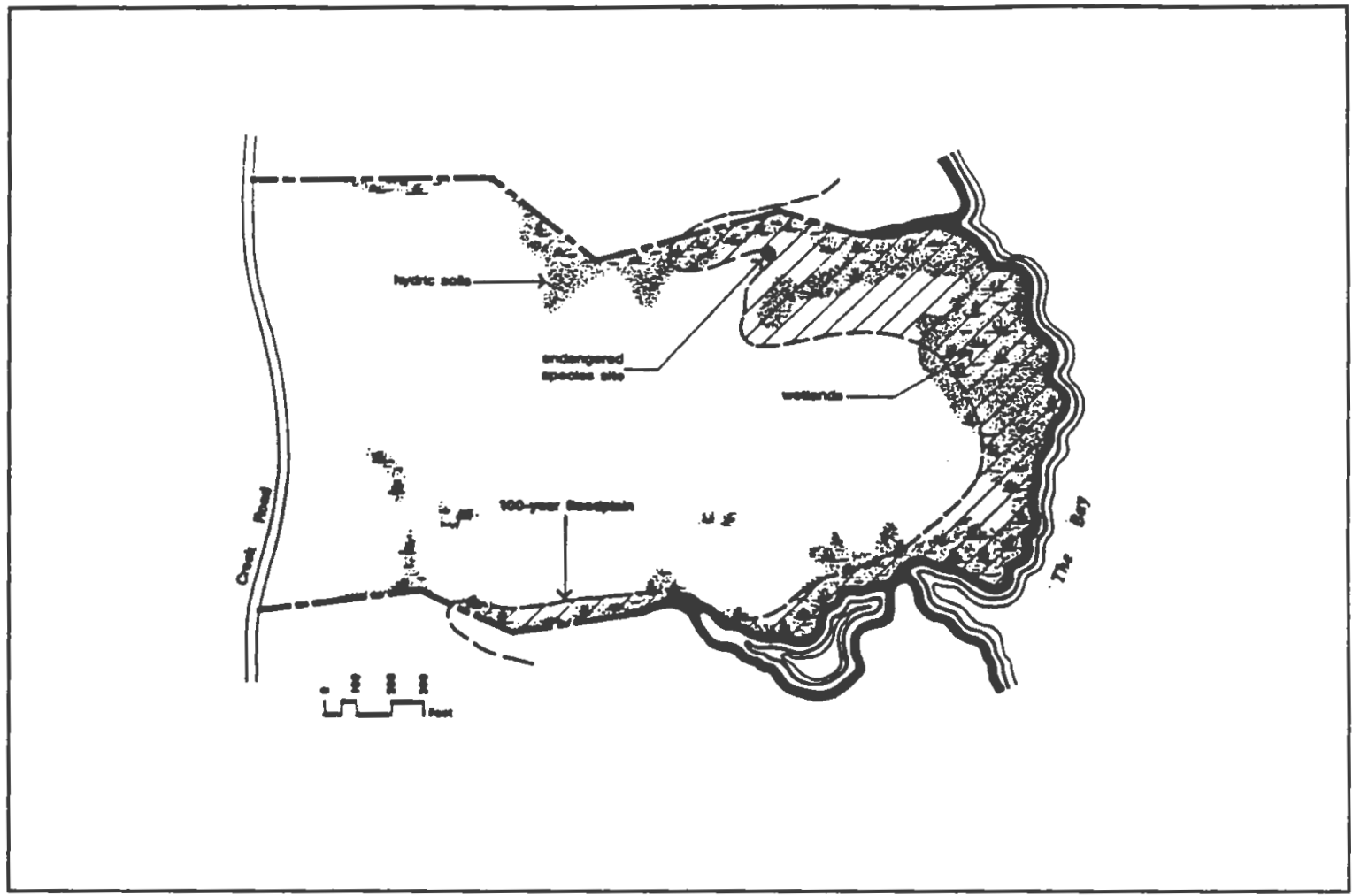

Source: Conservation Design for Subdivisions, by Randall Arend, 1996.

Figure 4-4 Layout of Conservation + Open-Space Areas

- Layout of house sites and active open-space areas:

Within the remaining area not set aside for conservation land, the allowable number of houses should be set up on the better soils, along with selected areas of active open-space, into an interesting pattern. As many of the houses as possible should look out onto some open-space from their front yard (Arendt 1994). Locations for LSA absorption systems, based on soils should be identified, and 
finally, development of some "back acreage" via flag-shaped lots could also be a consideration (Arendt 1996). This entire process should be attempted at least twice to allow for a more objective analysis.

See diagram below for an example:

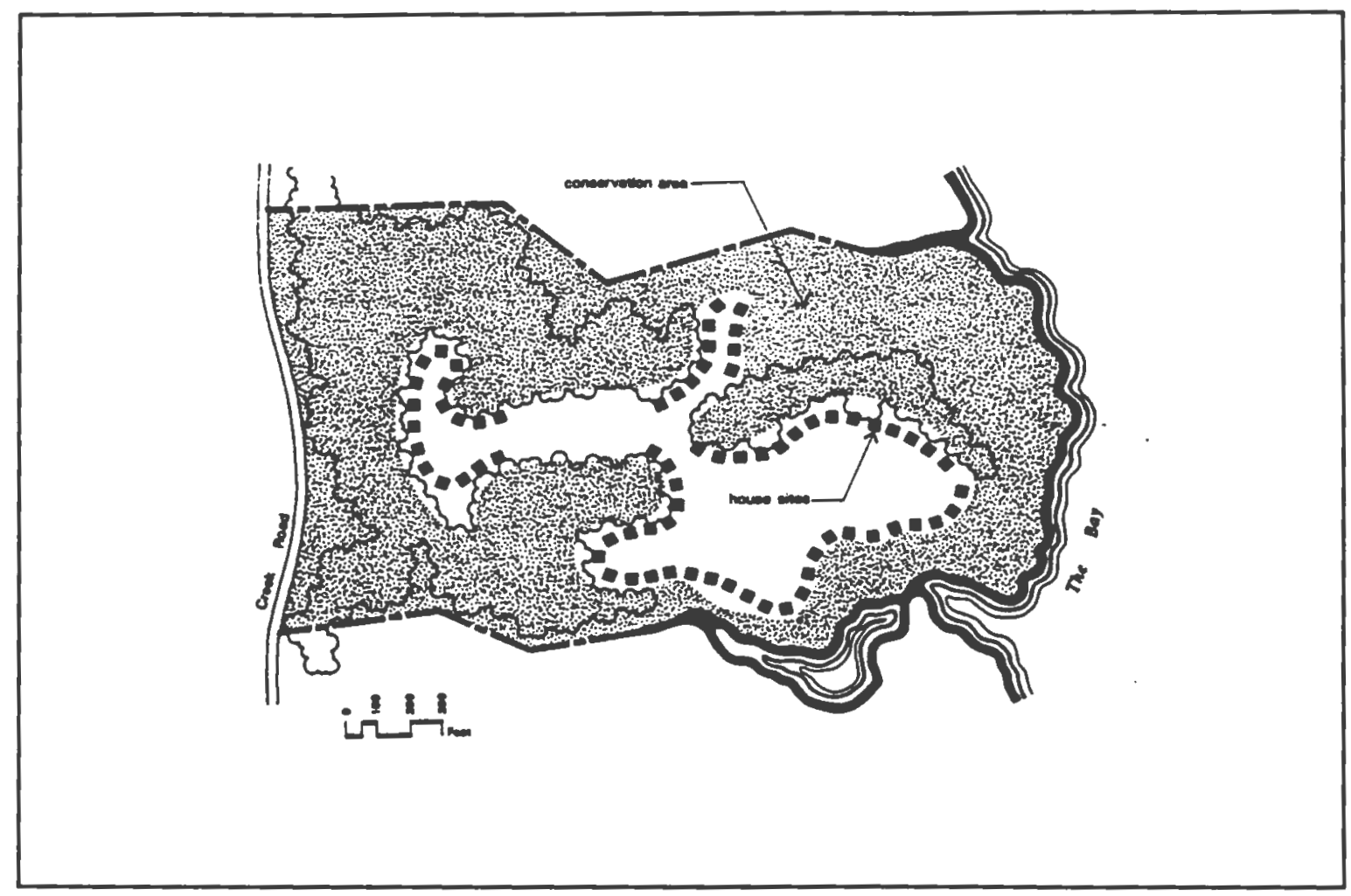

Source: Conservation Design for Subdivisions, by Randall Arend, 1996.

Figure 4-5 Layout of House Lot Patterns

- Layout of street alignments and nature trails:

Next, streets should be laid out in a pattern suggested by the houses, without excessive use of cul-de-sacs. Curvilinear roads are more interesting, taking advantage of unique or mature trees, scenic views, major rock outcroppings, stone walls, etc.

Then nature trails should be laid out using the following guidelines: they should same start and end at the same point, should take advantage of natural 
features and views, should avoid "sameness" throughout, and generally have a loop length of between one and three miles (Fogg 1990).

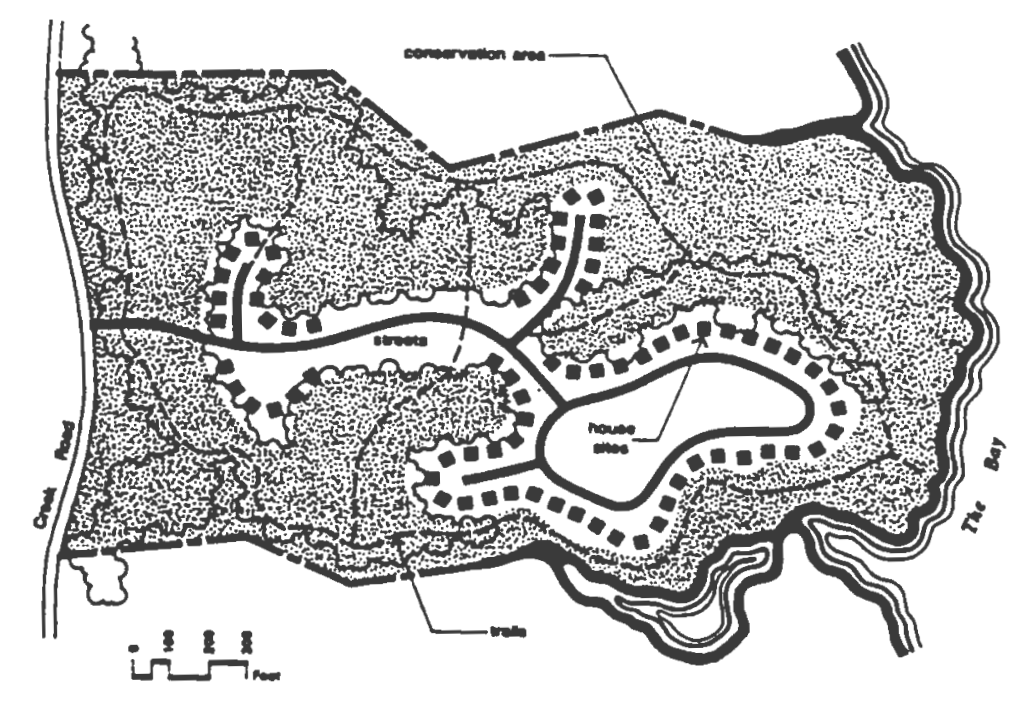

Source: Conservation Design for Subdivisions, by Randall Arend, 1996.

Figure 4-6 Layout of Streets + Nature Trails

- Layout of house lot lines:

The final step is the establishment of lot lines to achieve the required lot area and frontage requirements of the subdivision regulations. This step is done last in order to give more consideration up front to the siting of homes and open-space areas; this emphasis offers a more "organic" subdivision design, depending upon how progressive the community's subdivision regulations are!

See diagram on the next page for an example. 


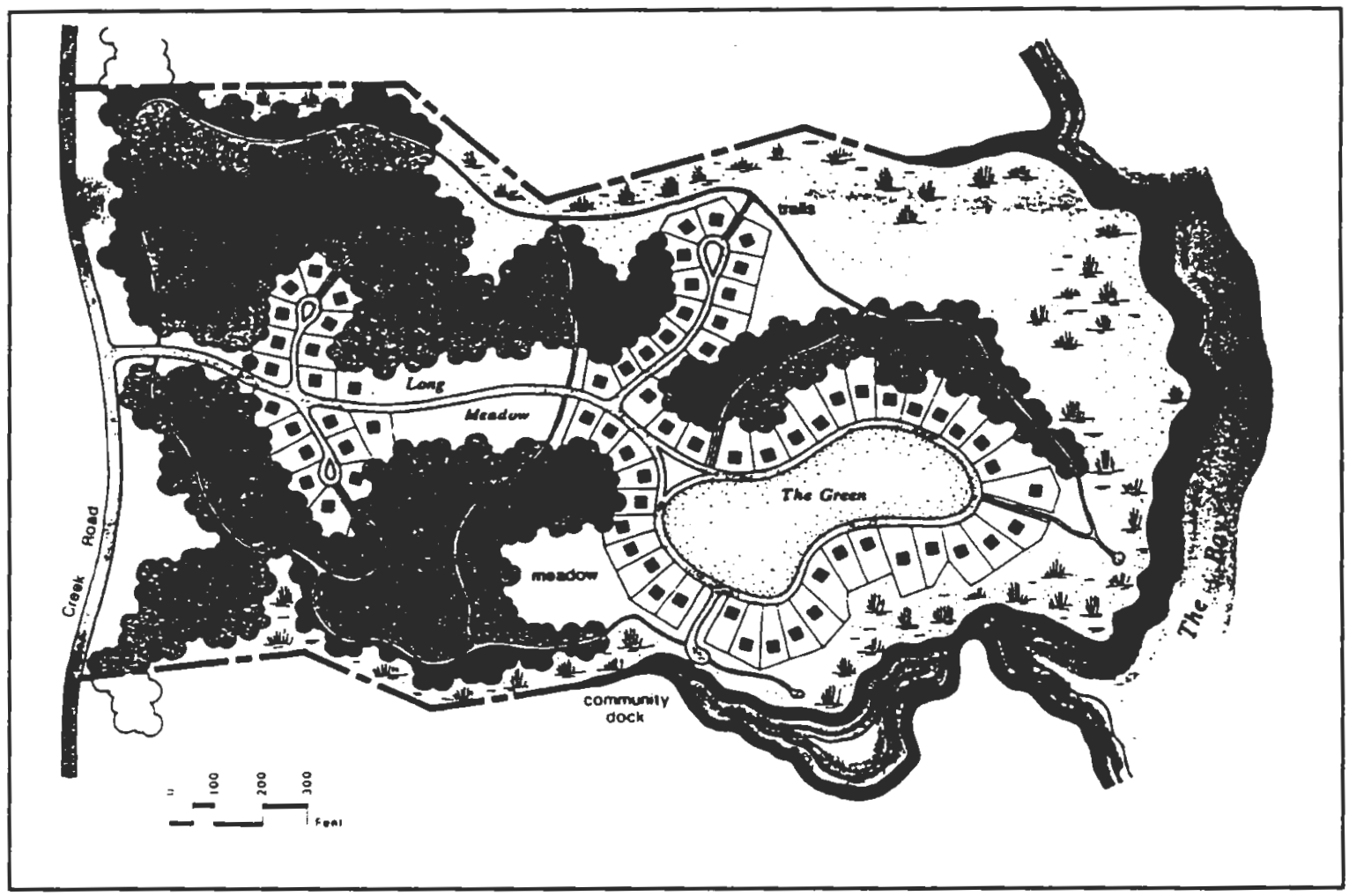

Source: Conservation Design for Subdivisions, by Randall Arend 1996.

Figure 4-7 Layout of Lot Lines

The result of this entire process should be one or two alternate conservation subdivision designs, each with a write-up explaining the solution arrived at. In carrying out the process itself, some elements will clearly be easy to locate on the site, but it is expected that certain values will be in conflict for the same space. Where alternative designs produce unresolveable areas of conflict, and this will likely be the case, a decision will need to be made about what value prevails, perhaps on the basis of the most practicable use of the land that can preserve the ecology. Being realistic, however, sometimes there will not be any reasonable alternatives that can keep the ecology of a certain portion of a parcel intact.

The concepts explained throughout this chapter will next be incorporated into an actual project in the town of Charlton, where two open-space design alternatives will be created for this study. It is the intent of this process to then identify specific areas in Charlton's current "Flexible Development" regulations that need to be improved upon. 


\section{Proposed Design Requirements: Discussion}

If the ultimate outcome of this study is to make changes to the existing Flexible Development regulations in Charlton (because they currently do not work well to preserve wildlife habitat, and inadequately connect people with nature or one another), it follows that the current requirements must be suspect. Starting off on a positive note, Charlton's 40 foot right-of-way (and 20 foot wide pavement area) requirements is reasonably progressive in minimizing impervious surfaces.

Studying rural design development standards a la Arendt, Yaro et. al, and Jarvis, however, makes it apparent that Charlton's cookie-cutter standards of lot frontage and lot area makes for cookie-cutter developments. Clearly one frontage size should not fit all lots, especially lots in cul-de-sacs or loop areas (refer to Figures 4-3 and 4-4 in this study); nor should lot area requirements be the same under different sewer design arrangements: public sewer, on-site septic, or common (LSA) systems.

In order to conserve 50 percent of land as open space, lot sizes would need to be reduced by at least 50 percent to accomplish this objective; this would mean a new minimum lot size of 30,000 square feet for houses in the Agricultural zone. An additional consideration should be made regarding the provision of amenities such as nature trails and common open space, mailbox areas, gazebos, etc.; these items cost extra to the developer, and compensation needs to be provided so that a legal takings challenge is not forthcoming. This compensation can be made by the allowance of additional house lots over and above the number of lots allowed via conventional subdivision standards. These incentive lots could perhaps be smaller in size, 20,000 square feet for example, provided that they are clustered around a common septic system.

Frontage requirements could be altered to allow for variations based on lot location, as long as some minimum lot width existed at the front setback line. For example, with a requirement of having a front setback range of 20-30 feet, lot width would need to be a minimum of 80 feet in that range area, with minimum side setbacks of 
10 feet. On a cul-de-sac, as an example, this would allow for a house 60 feet wide (a 40 foot wide main structure with a 20 foot wide garage could fit in this space, more than adequate for a 3-bedroom home). As can be seen in Figure 4-8, this performance standard around a cul-de-sac would allow frontage for lots $2,3,4$ and 5 to be 50 feet when the cul-de-sac is laid out as shown. When the cul-de-sac is 100 feet in diameter, this creates enough room for 6 lots, and allows a green space to be left in the middle.

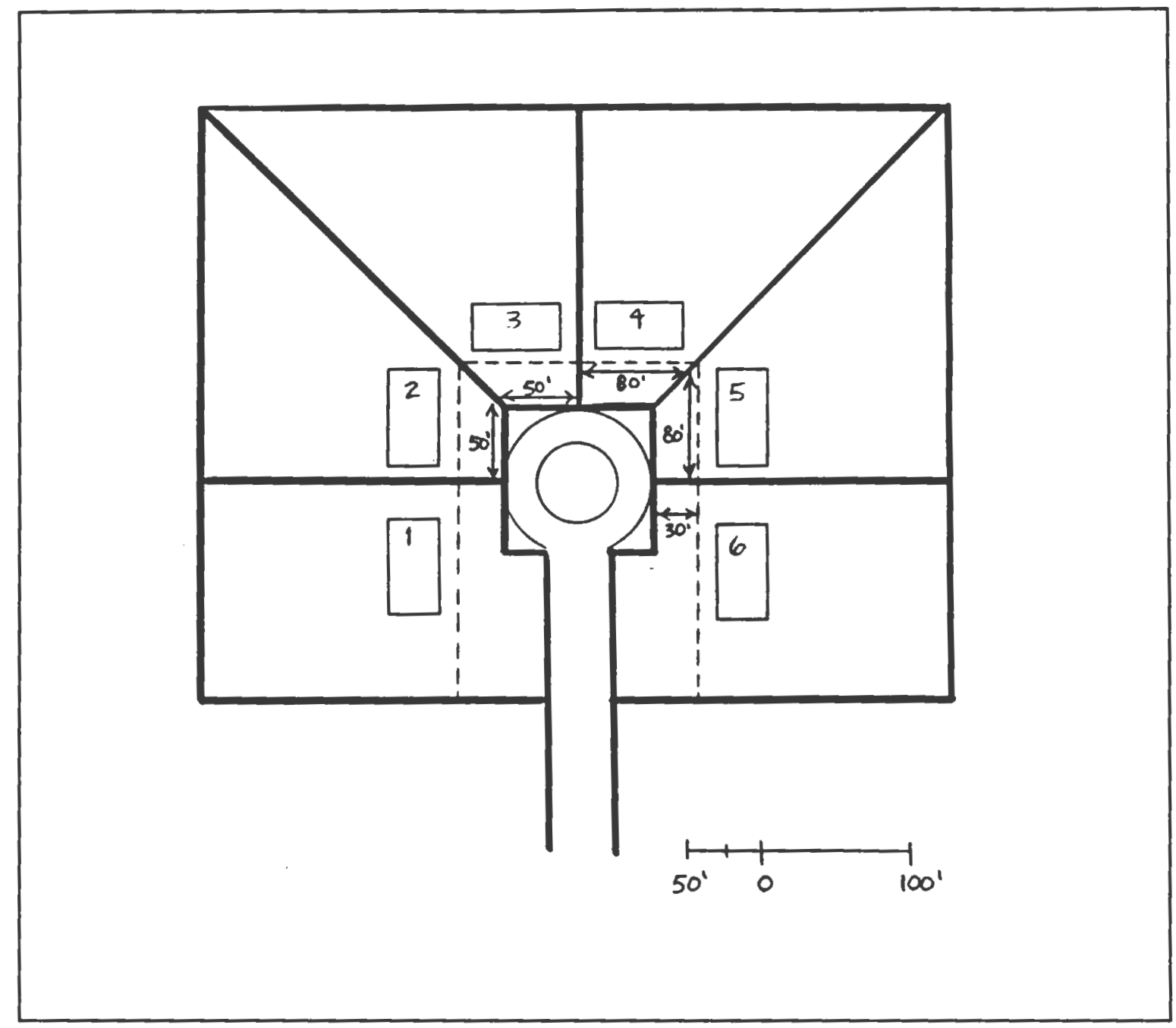

Figure 4-8 Proposed Cul-de-Sac Design Requirements

\section{Basic Design Requirements}

Some basic design requirements are now proposed for a more progressive approach to open-space subdivisions in Charlton. These requirements are highlighted in 
Figure 4-9. In terms of other considerations within the scope of this study, subdivisions with over six homes are required by the Town's subdivision regulations to have "fire ponds", filled with stormwater runoff, and utilized as a water source during a fire. This will be a requirement for this design project, but other technical considerations, such as stormwater detention basins, drainage issues, etc., will not be part of the project's design requirements.

Figure 49

\section{PROPOSED \\ CHARLTON OPEN-SPACE REQUIREMENTS}

\begin{tabular}{|c|c|c|}
\hline Requirement & $\begin{array}{l}\text { Lots with Individual } \\
\text { Septic Systems }\end{array}$ & $\begin{array}{c}\text { Lots with Common (LSA) } \\
\text { Septic Systems } \\
\end{array}$ \\
\hline $\begin{array}{c}\text { Minimum required lot } \\
\text { size }\end{array}$ & 30,000 sq.ft. & 20,000 sq.ft. \\
\hline $\begin{array}{l}\text { Minimum natural \& } \\
\text { active open space }\end{array}$ & $50 \%$ & same \\
\hline $\begin{array}{l}\text { Road right of way total } \\
\text { width/paved width }\end{array}$ & $40 \mathrm{ft} . / 20 \mathrm{ft}$. & same \\
\hline $\begin{array}{c}\text { Minimum cul-de-sac } \\
\text { dimensions }\end{array}$ & $\begin{array}{c}100 \mathrm{ft.square}(100 \mathrm{ft} . \text { diam } / 20 \mathrm{ft} \text {. } \\
\text { wide road) }\end{array}$ & same \\
\hline $\begin{array}{c}\text { Minimum frontage on } \\
\text { cul-de-sac }\end{array}$ & $75 \mathrm{ft}$. & $50 \mathrm{ft}$. \\
\hline $\begin{array}{c}\text { Minimum frontage all } \\
\text { other lots }\end{array}$ & $100 \mathrm{ft}$. & $80 \mathrm{ft}$. \\
\hline $\begin{array}{l}\text { Required front setback } \\
\text { (within range) }\end{array}$ & $20 \mathrm{ft} .-30 \mathrm{ft}$. & $20 \mathrm{ft} .-40 \mathrm{ft}$. \\
\hline $\begin{array}{l}\text { Minimum lot width } \\
\text { requirement at front } \\
\text { setback line (all lots) }\end{array}$ & $100 \mathrm{ft}$. & $80 \mathrm{ft}$. \\
\hline $\begin{array}{c}\text { Required side yard } \\
\text { setbacks }\end{array}$ & $15 \mathrm{ft}$. & $10 \mathrm{ft}$. \\
\hline $\begin{array}{l}\text { Fire Pond Required } \\
\text { (over } 6 \text { lots) }\end{array}$ & Yes & same \\
\hline
\end{tabular}

In the next chapter, the foregoing concepts and ideas will be utilized for an ongoing open-space subdivision project in Charlton, Schofield Heights. 


\section{Ch. 5}

\section{Proposed Open-Space Design: Schofield Heights}

\section{Background}

Originally submitted as a conventional subdivision design in 1987 , the plan was denied approval by the Planning Board on the grounds that the lots, as designed, did not conform to the dimensions recently approved with the new zoning bylaw (the date of that Special Town Meeting, April 4, 1987 is when Charlton formally adopted zoning).

The Charlton-Oxford border runs north-south through most of the parcel's eastern section. The small portion of the parcel that lies in Oxford varies in width from 30 feet to 600 feet wide in places, and the fact that the site straddles the two towns has been an additional problem in terms of access into the site.

In 1988, the developers got approval from the town of Oxford to subdivide 3 lots of this parcel with a new road off of Conlin Road, all of which lie in Oxford. In 1991, when the developer came to the Charlton Planning Board with a revised subdivision plan, it was again denied; this time on the basis of accessing a Charlton development through another town. The developer sued the Planning Board, but the Board's decision was upheld by the court; no appeal was made.

More recently, in June of 1997 the developer came back to the Planning Board to see if they could try again with a new plan, and the Board was willing to look at their new plan after it was worked on, and suggested they work with the Town Planner in making it. This study is part of this process.

\section{Overview of Site Environs}

Located near the southeast comer of Charlton, directly on the Oxford town line (see Figure 5-1), the proposed site consists of nearly 104 acres of land area, some of 
which abuts Buffumville Lake, a prominent state park recreation area, featuring swimming, picnicking, boating, and walking trails. Very broadly, the site is rectangular in shape, the long sides oriented north/south with Conlin Road just off the east boundary, and Buffumville Lake just off the west boundary (see Figure 5-2). Between Conlin Road and the lake, which is a distance of about 1800 feet, the site elevation goes down from 685 feet (above sea level) to 529 feet, a total drop of 156 feet. Using a calculation for slope $(($ rise $\div$ run $) \times 100)$ this equates to the natural slope of the site being equal to 8.67 percent, a moderate slope (Marsh 1991).

Looking still at Figure 2, most of the project site and surrounding area is still heavily wooded/forested, and limited in the extent of development. Looking around the perimeter of the site we have Conlin Road and existing houselots to the east, Oxford Road and existing homes to the South, Turner Road and some houselots to the North, and to the west is the water and grounds of Buffumville Lake and recreation area. Just north of Buffumville Lake is a stream called Little River, which is considered an estimated habitat area for some rare wildlife. Located further away in the northwest section is a hiking trail known as the Mid-State Trail, which appears to end at the electric power lines near Putnam Hill.

\section{Analysis Phase}

Taking this brief introduction further, other natural and cultural features either surrounding the project site (see Figure 5-2) or on the site itself (see Figure 5-5) should be researched and analyzed for any synergy that might be exploited for the benefit of creating open-space developments that connect people to nature and one another and for these analyses). Various maps will be needed for this research, and are available for this study in Appendix ' $\mathbf{C}$ '. Likewise, a wildlife corridor analysis needs to be conducted to identify areas on-site and within 200 meters (Desbonnet et al, 1994) that have potential as protected habitat corridors (see Figure 5-3). 
It is clear after looking at the project site through these three analysis "lenses" that the western portion of the parcel should be left in its natural state as contiguous open space, serving as a wildlife corridor for the Little River, which runs north and south. Additional synergy might be gained by tying into the Mid-State Trail, and by keeping intact the stone wall that runs east to west at the northern end of the site.

\section{Design Phase}

Four broad goals are sought with this project: to conserve a contiguous wildlife corridor both on-site and with adjacent parcels; to re-connect people with their natural surroundings; to re-connect people with one another; and to have a financially feasible design. It is felt that this last goal needs to come at the end of the process, and not, however, drive it from the very beginning. A fifth goal for the purposes of this project is to take a look at designing housing clustered around common septic fields, to see what it might look like, and whether having such a design could help achieve some of the other goals as well.

The design phase starts with seeing how many units can be built using the existing subdivision and zoning standards for this area in Charlton. The basic design guidelines for a conventional subdivision in this part of Charlton, which is in the Agricultural zoning district, is minimum 60,000 sq.ft. lots, each having 175 feet of frontage, minimum. The standard width for a subdivision road in Charlton is $35 \mathrm{ft}$., in a road right-of-way that is 60 feet wide. Utilizing these guidelines, fifty lots can be created, each having a minimum portion of upland area of 40,000 sq.ft. (see Figure 5-7) An additional lot is made available for the creation of a fire pond, which is required in subdivisions of over six homes. Charlton's existing Flexible Development regulations allow for an additional 10 percent bonus of houses, as long as the minimum amount of open space remains. Keeping this bonus provision would allow an extra five houses to be built for the Schofield Heights project, for a new total of fifty-five. An important difference from the existing regulations, 
however, is that the minimum open-space goal for this project is now 50 percent of the original parcel, instead of twenty-five percent.

Having conducted analyses of on-site and nearby natural and cultural resources, as well as a wildlife corridor analysis, the next step involves the selection of conservation areas. Since the analyses have pointed to preserving the western portion of the project site, a first choice is to select a contiguous area immediately around the on-site wetlands (see Figure 5-8). This area becomes a starting point for "Scheme 'A". Scheme ' $\mathrm{B}$ ', starts off the same, but widens up at the middle, providing for a deeper wildlife corridor area. These two schemes form the new project limits for the soon to be altered landscape.

The design philosophy of Scheme ' $\mathrm{A}$ ' is to design a condensed version of a conventional subdivision, but to have most of the houses facing some form of open-space. A recent survey, as a matter of fact, has shown that given a choice, most people prefer having their homes face towards an open-space areas (Arendt 1996). Scheme 'B' looks at clustering a significant portion of homes in an intimate scale around a common septic system area, which also serves as active open-space for these homes. It is hoped that this design would ultimately lead to a greater percentage of open-space left undisturbed.

Using the design standards put forward earlier in Figure 4-10, schematic designs for the layout of houses, "created" open-space, roads and trails are then created for the developable areas in each scheme, pitting the "efficient" allocation of space against the "relation" of structures to nature and people. Scheme 'A' creates a "town common" area, on which ten homes face directly, and attempts to face as many remaining homes as possible towards open-space, with all lots containing a minimum area of 30,000 sq.ft.. Most of the stone wall running east-to-west towards the northern portion of the site is retained where possible, retaining a bit of the site's heritage. Additionally, a small openspace area to the east could serve as a common mailbox area; and directly across the street, where the trail begins, could also be made into a picnic area and/or a playground 
(see Figure 5-9). These common areas are reachable by a sidewalk located on one side of the subdivision's main roads. The final design for Scheme ' $A$ ' is shown in Figure 5-10.

Looking at the schematic in Figure 5-11, scheme 'B' is oriented around several clusters of small neighborhoods. Five such neighborhoods consist of six (6) 20,000 sq.ft. lots clustered around a common open space used for the septic system and an extra reserve area (see Appendix 'D' for more detailed septic design). These common areas can be used as play areas, and can be landscaped with small plantings of flowers and shrubs, and in the case of the extra reserve area, could be planted with trees. Having this common area for the septic system allows individual houselot sizes to be reduced to 20,000 sq.ft., giving the cluster more of a New England village scale, where neighbors get to see and talk with one another more often, allowing a deeper level of community to occur. A common mailbox area, picnic area, and playground are provided near the trailhead, and can be reached via a sidewalk located on one side of the two main roads (see Figure 5-12 for Scheme B's final proposed design). These amenities could be initially provided by the project developer, or perhaps afterwards by the homeowners' association, which ultimately becomes responsible for the maintenance and improvements of common areas.

These two designs offer different approaches to preserving a large portion of open-space, while at the same time connecting people to that open-space and to each other. Scheme 'A' looks at tying the whole subdivision together around the common green area; Scheme 'B' takes the smaller group approach, while bringing everyone together at a common node (the mailbox/picnic/trailhead area). In the next chapter we will take a look at the results of these designs, and whether they met the primary goals set forth for them earlier. Recommendations for changes to Charlton's existing Flexible Development regulations and design standards will also be made. 


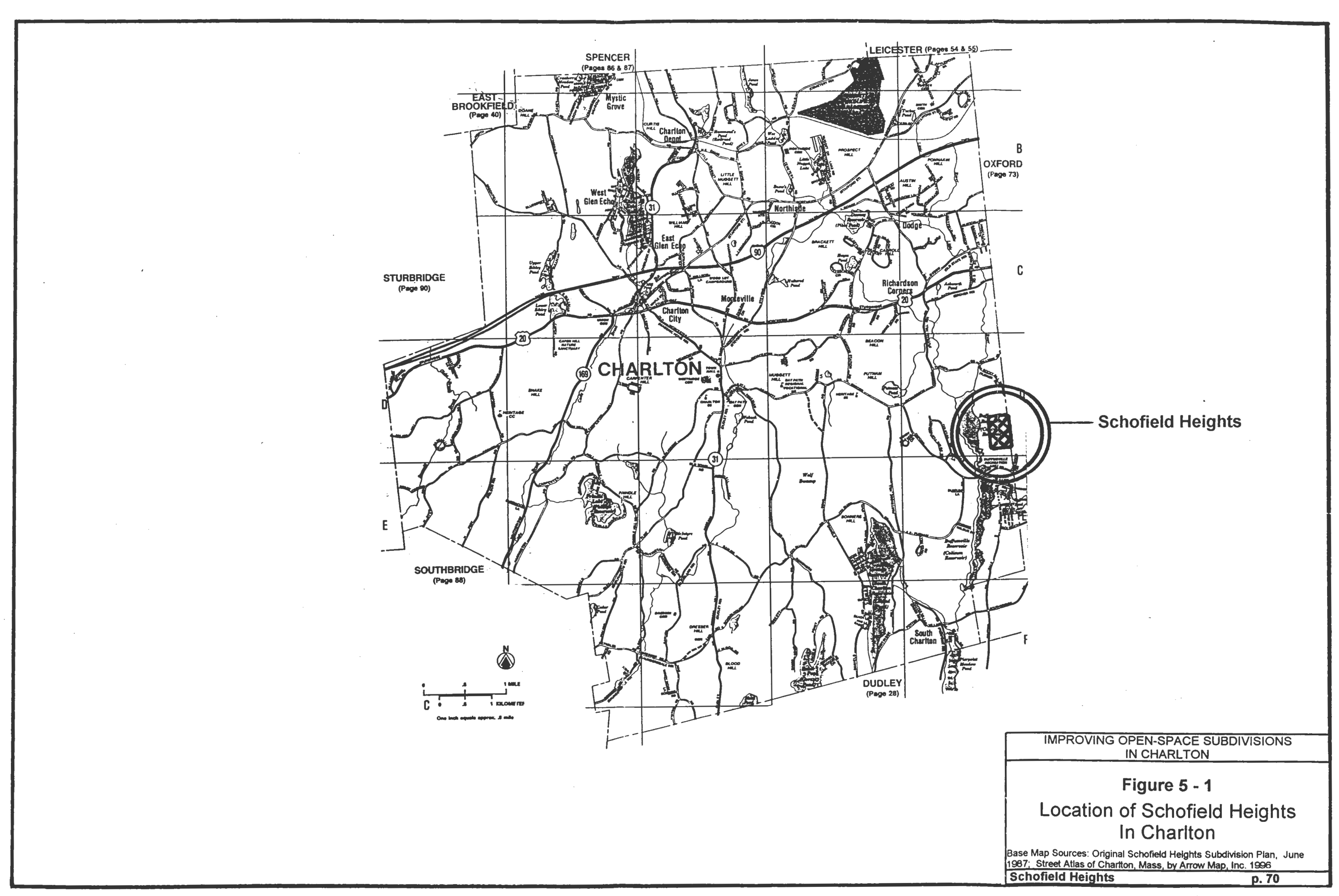




\section{Nearby Natural + Cultural Resources \\ (found within a 3/4-mile radius from project site center)}

\begin{tabular}{|c|c|c|c|c|c|c|}
\hline \multirow[b]{2}{*}{ Resource } & \multicolumn{2}{|c|}{ Date: $10 / 11 / 97$} & \multicolumn{3}{|c|}{ Project Name: SCHOFIEZD HEGrHTS } & \multirow[b]{2}{*}{ Map Source(s) } \\
\hline & \multicolumn{2}{|c|}{$\begin{array}{l}\text { Within Locus? Outside Locus } \\
\text { ( } 1 \text { mile radius from But Should } \\
\text { profect stite center) Still Consider? }\end{array}$} & $\begin{array}{l}\text { Value } \\
\text { (in using with } \\
\text { project site) } \\
\text { (from } 0 \text { to 4) }\end{array}$ & How to incorporate/ utilize & $\operatorname{Map}(\mathbf{s})$ & \\
\hline 1 Agricultural Land? & XY QN & QY & 1 & SMKU HORSE PASTURE NEARET & Agricultural Land in Chartion & MassGIS \\
\hline 2 Woodlands/Forests? & 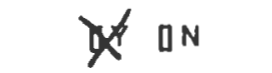 & QY & 4 & INCORPORATE AS WILDUFE CORRIDOR & Aerial photos; Seamless USGS Map & Chartton Planning Board; MassGIS \\
\hline 3 Aquifers? & QY XK & QY & - & $N / A$ & $\begin{array}{l}\text { Water Resources in the French } \\
\text {-Quinebaug Rivers Basin, Mass. } 1988\end{array}$ & Mass. DEP/ Dept. of Water Resources \\
\hline 4 Rare Wildilife Habitat? & 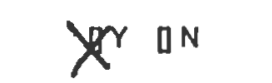 & QY & 4 & INCORPORATE INTO MLDUEE COKKIDOR & Estimated Rare Wildifif Habitat, Chartton & Mass. Natural Heritage Program \\
\hline 5 Streams/Rivers? & $X X N$ & DY & 4 & INCORPORATE INTO WILPLIPE CORRIPOL & Seamless USGS Map & MassGis \\
\hline 6 Pondshakes? & 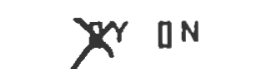 & QY & 3 & INCOK POLATE INTO WILDUPE CORRIDOL & Seamless USGS Map & MassGis \\
\hline 7 scenic Areas? & XYY ON & QY & 2 & BUFFUMVILE REREATOW AREA, CONLW & Map of Scenic Landscapes, Chartion & Chartton Open Space Plan, 1996 \\
\hline 8 Geological Features? & $\Delta Y X N$ & DY & - & $N / A$ & -Map of Geological Features, Chartion & Chartton Open Space Plan, 1996 \\
\hline $\begin{array}{l}\text { Cultural, Archeobogical + } \\
9 \text { Historlc Features? }\end{array}$ & $X \& \quad 0 N$ & DY & 1 & SMALL GFAVEYARD NEACBY & $\begin{array}{l}\text { Map of Cultural, Archeological + Historic } \\
\text { Features, Chartion }\end{array}$ & Chartton Open Space Plan, 1996 \\
\hline 10 Open Space / Recreational & $X Y x^{\prime} \quad n$ & DY & 2 & $\begin{array}{l}\text { TIE INTO EXISTIN MID-STATE TRAL } \\
\text { THKU BUFEUMVLE STATE PAEK? }\end{array}$ & $\begin{array}{l}\text { Open Space Resources, Chartion; } \\
\text { seamless USGS map. }\end{array}$ & $\begin{array}{l}\text { Chartton Open Space Plan, 1996; } \\
\text { MassGIS }\end{array}$ \\
\hline
\end{tabular}

\begin{tabular}{|c|}
\hline \multicolumn{2}{|c|}{ IMPROVING OPEN-SPACE SUBDIVISIONS } \\
IN CHARLTON \\
\hline Figure 5 - 2 \\
Analysis: Nearby Natural/Cultural \\
Resources \\
\hline schofield Heights \\
\hline
\end{tabular}




\section{Wildlife Corridor Analysis}

(Potential within 200 meters of parcel boundaries)

Date: $10 / 11 / 97$

Project Name: SCHOFIED HGGGHTS

Project Location: CONLIN RD. / TURNER RD

Potential

Value

Adjacent to wildifie habitat)

Habitat Which Boundaries? frrom 0 to 4

\begin{tabular}{|c|c|c|c|c|}
\hline Habitat & & Which Boundaries & om 0to 4) & How to incorporate/ utilize \\
\hline 1 Rare Widdlife Habttat located within 200 meters? & $X\langle Y \square N$ & क्रX XE OW & 4 & WEST POETION OF SIIE SHOULD BE CONSERVAD. \\
\hline 2 Stream or river located within 200 meters? & ar & QN IS TE QW & - & \\
\hline 3 Woodlands FForests located within 200 meters? & $x / 4$ an & DN OS DE YN & 4 & WEST POKTION OF SITE SHOULD BE CONSERNED \\
\hline 4 Pondshakes located within 200 meters? & $X x \operatorname{an}$ & ON OS OE XNO & 3 & MOST OF BUFFUMVILE RELRERTION AREA = NATURAL \\
\hline 5 Marsh bocated within 200 meters? & ar & IN DS DE DW & - & \\
\hline 6 Swamp located within 200 meters? & or $X X$ & ON OS OE OW & - & \\
\hline
\end{tabular}

Node: Maps to use in finding this information: Aerrial photos; USGS Map

\begin{tabular}{|c|}
\hline IMPROVING OPEN-SPACE SUBDIVISIONS \\
IN CHARLTON \\
Figure $5-\mathbf{3}$ \\
Analysis: Wildlife Corridor \\
\hline schofield Heights \\
\hline
\end{tabular}




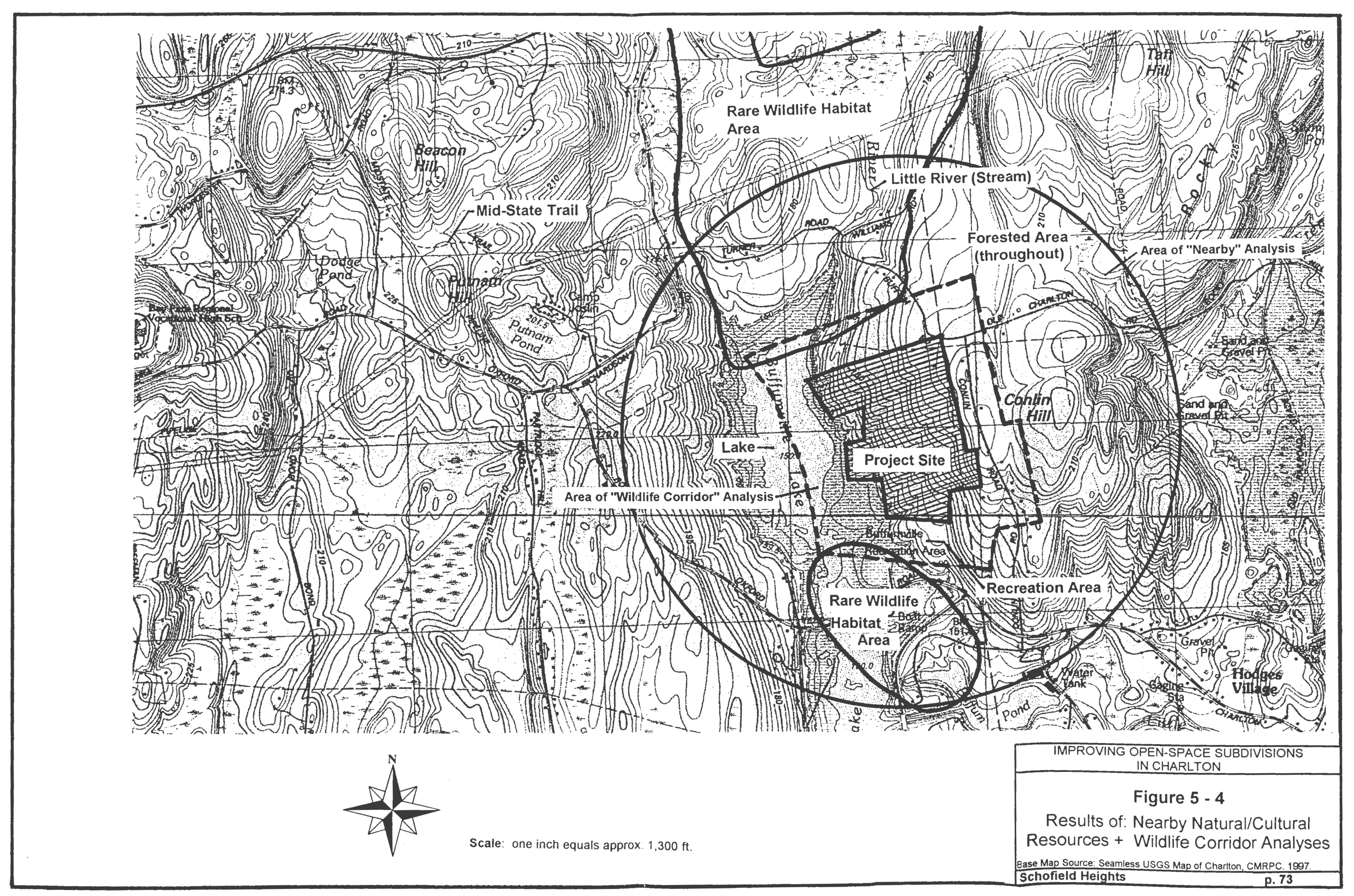




\section{On-Site Natural + Cultural Resources}

Date: $10 / 11 / 97$

Project Name: SCHOFIED HERGHTS

Project Location: CONLIN RD./TURNER RD.

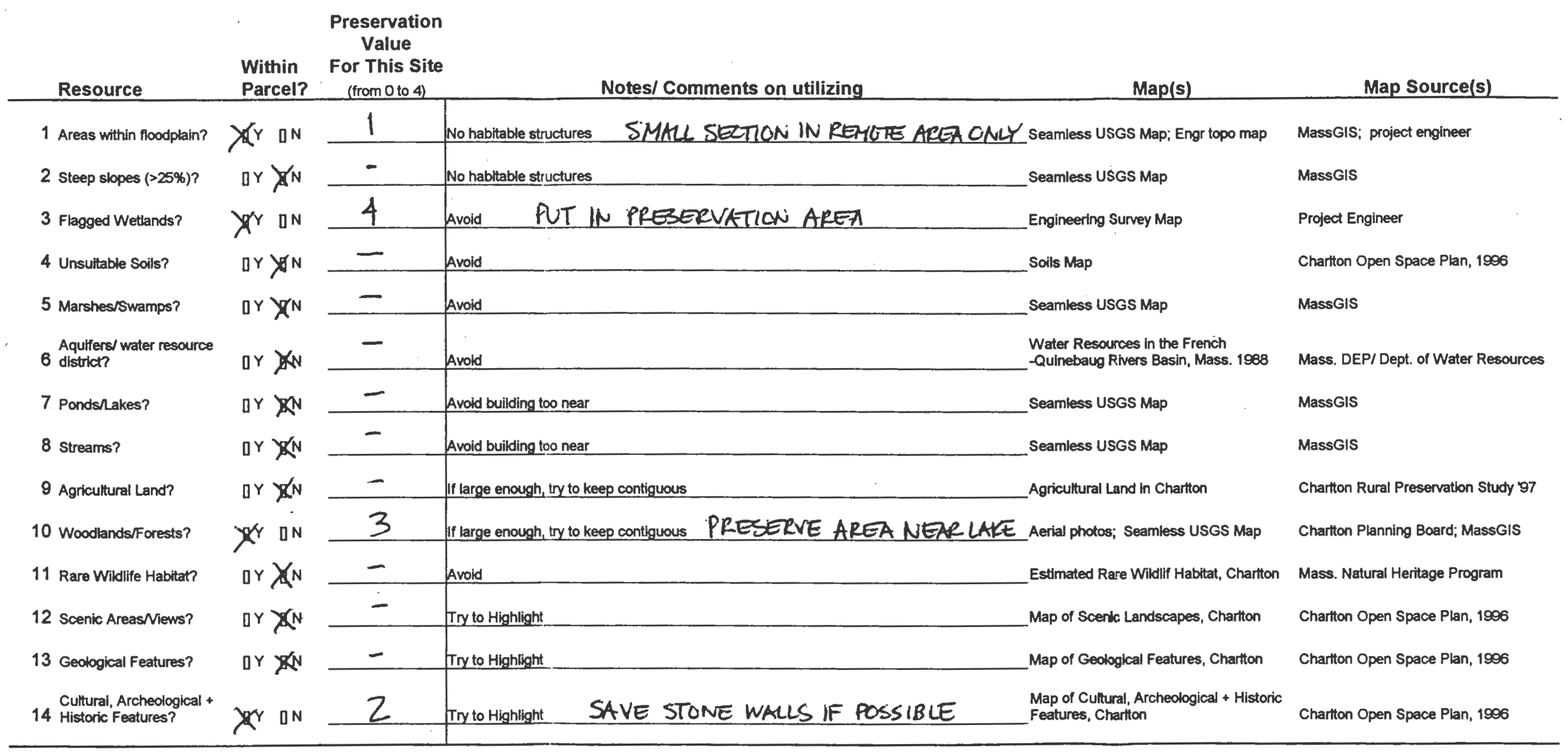

IMPROVING OPEN-SPACE SUBDIVISIONS IN CHARLTON

Figure 5 - 5

Analysis: On-Site Natural + Cultural

Features 


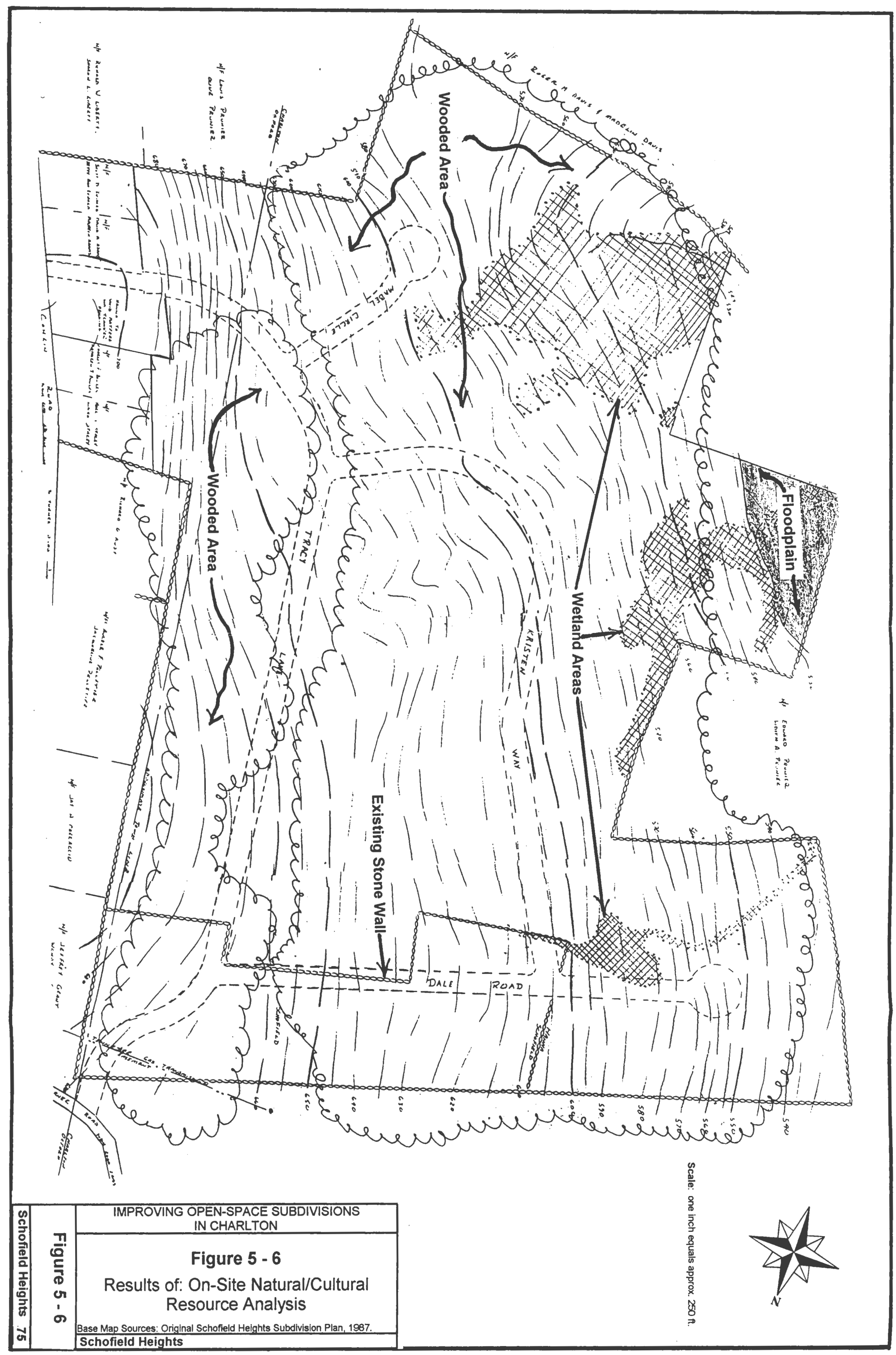



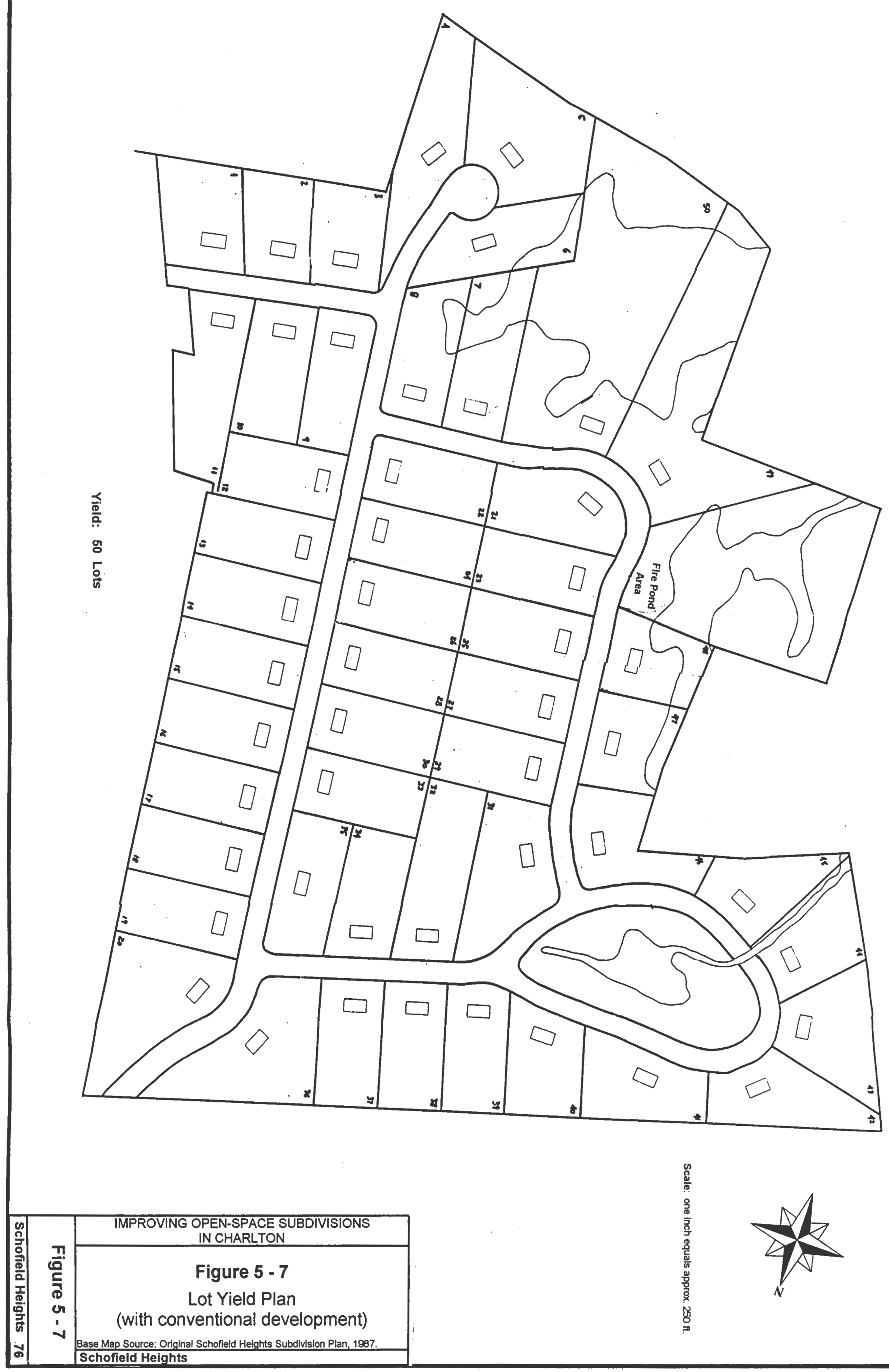


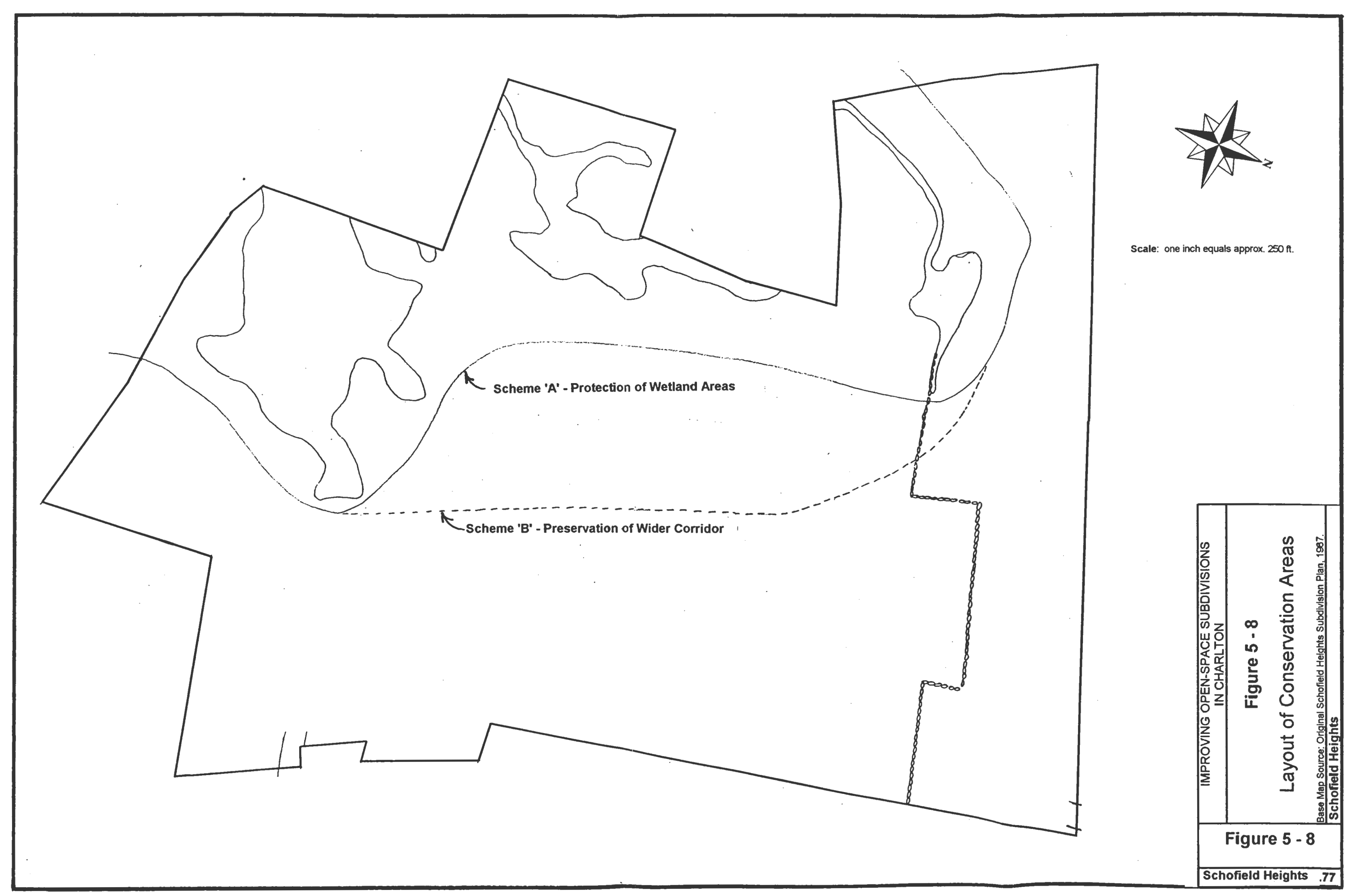




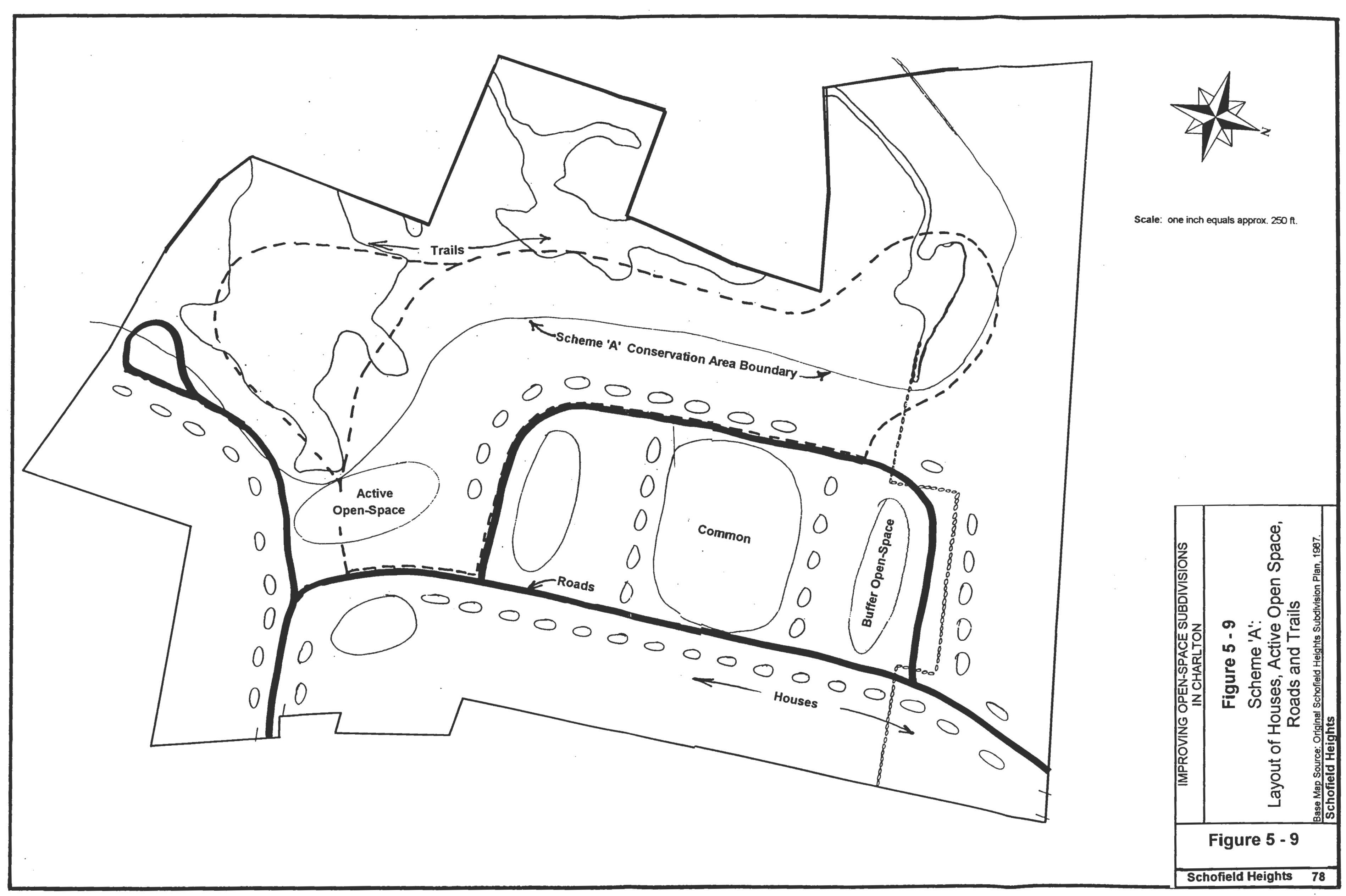




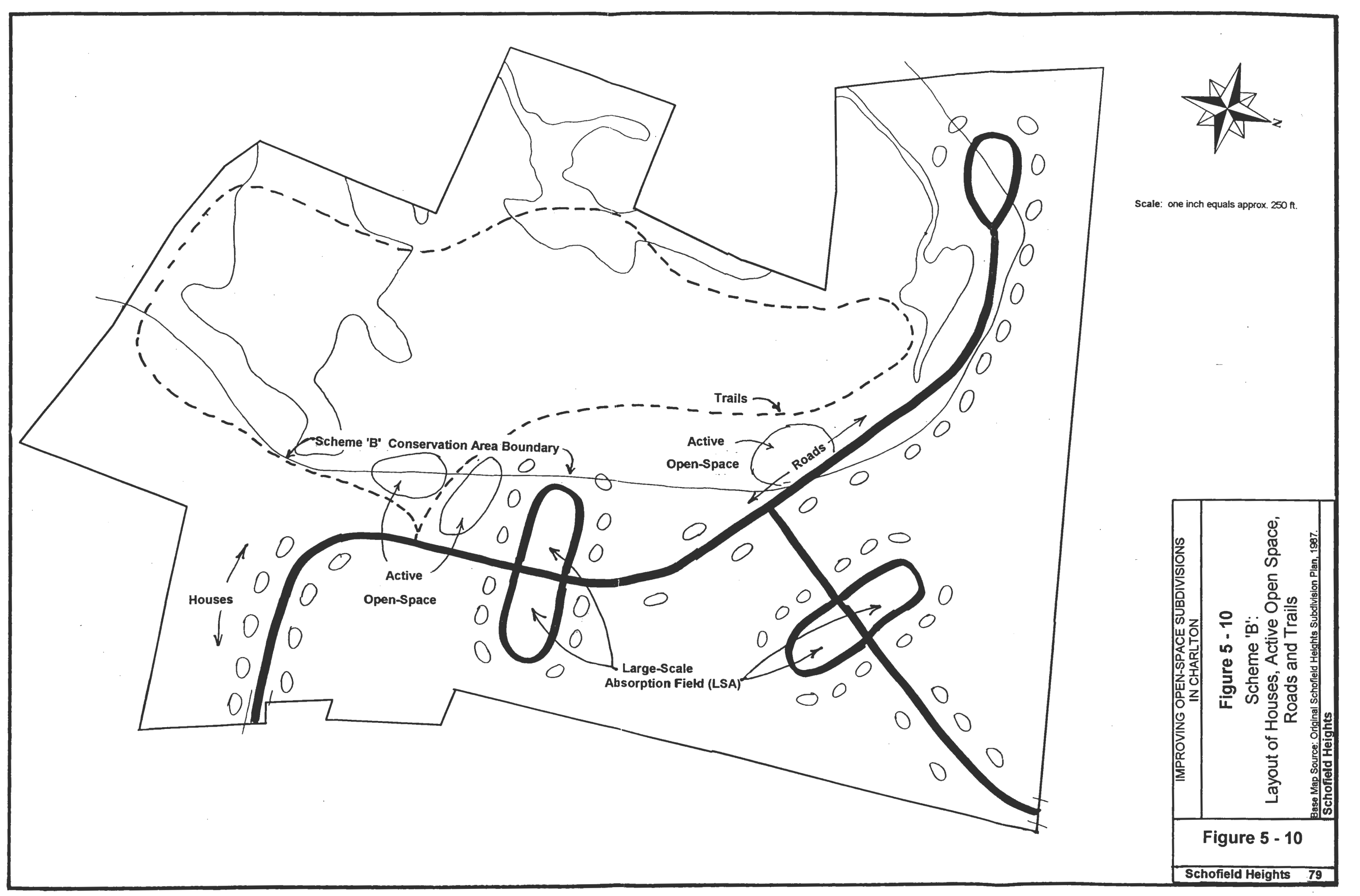




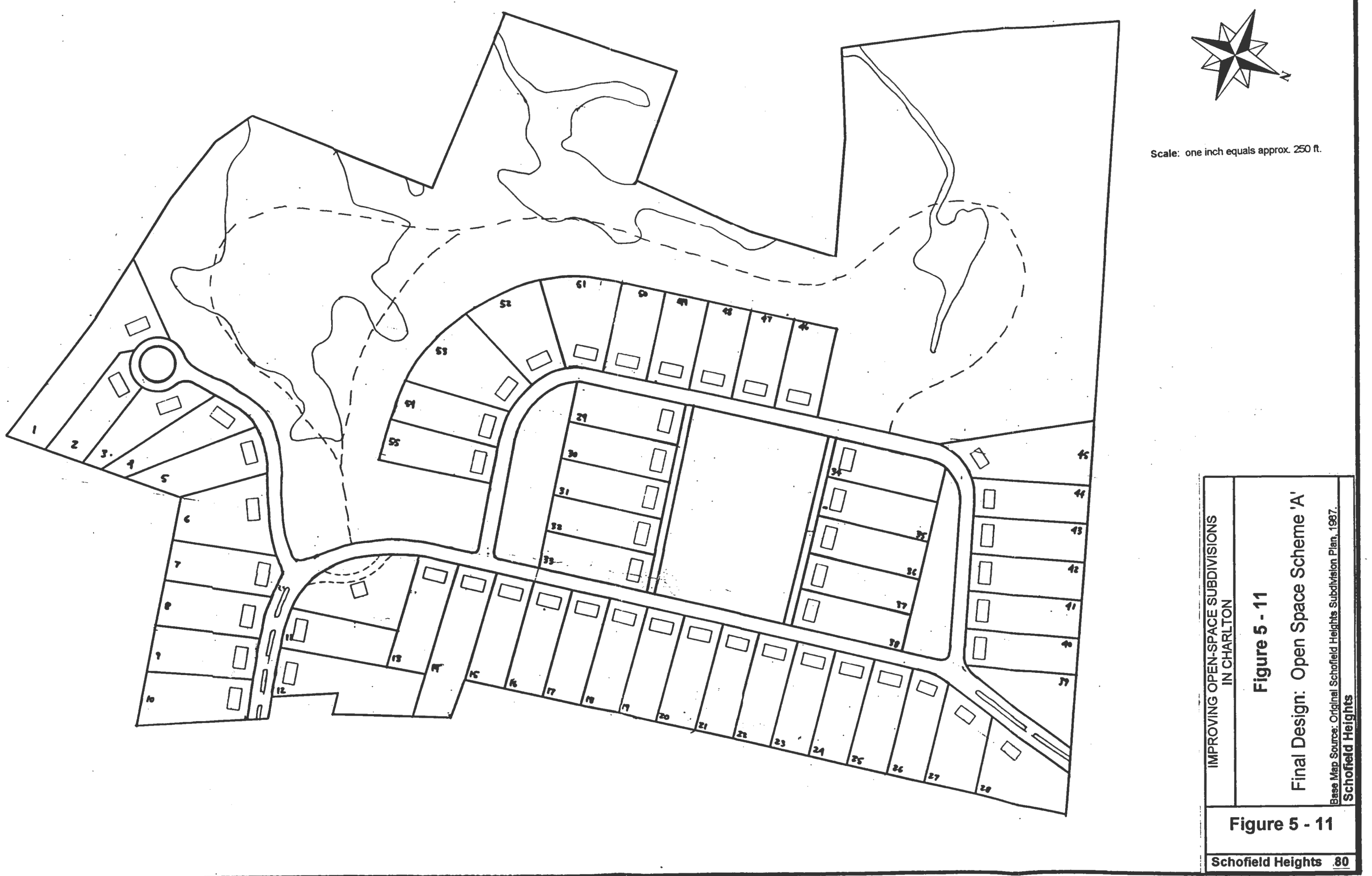



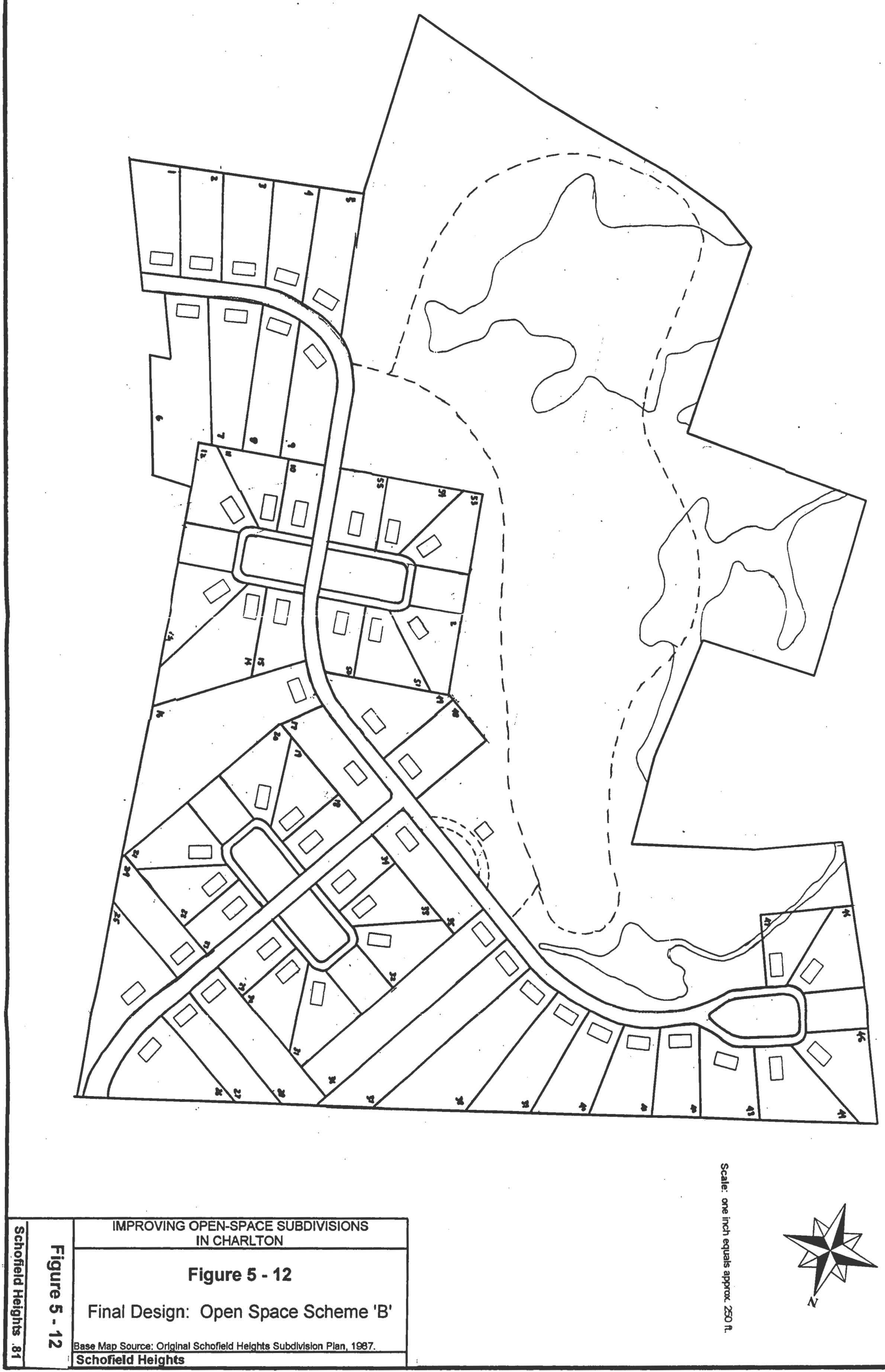


\section{Ch. 6}

\section{Findings and Recommended Changes}

The results of the proposed designs can be reviewed quantitatively and qualitatively. First, we shall look at the values that can be measured, such as acreage of land used for house lots, open space, and roads; secondly we will review the quality of the spaces that have been created with the designs.

A quantitative comparison can be seen in Figure 6-1, which predictably shows that road area and road length are significantly lower with schemes ' $A$ ' and ' $B$ ' than with the conventional subdivision design, which saves significant costs for the developer. A primary objective is met with the total percentage of open-space in both schemes ' $\mathrm{A}$ ' and 'B' coming out above 50 percent for each. Surprisingly, Scheme 'B', which has 29 smaller, 20,000 square foot lots, actually saves slightly less open-space than scheme 'A', though it leaves about 3 acres more land in an undisturbed state than does Scheme ' $\mathrm{A}$ '.

Qualitative assessment of the two proposed schemes was accomplished by asking local real estate, engineering, and development professionals, along with local officials to review the designs and then to fill out a short questionnaire with their reactions. These comments can be seen in Appendix ' $\mathbf{E}$ '.

Overall, the main comments related to the open space available on-site, and to the length of roadways in each of the schemes. The amount and perceived quality of the open space generally received positive comments, while the length of roadway generally drew incredulous comments. Following this up with one of the respondents, a real estate broker, I learned that many developers want to have homes on both sides of the road in order to justify its cost (and that he actually had only looked at the design instead of reading the chart identical to figure 6-1 which had been provided for his review). 
Perhaps the others had just eyeballed the designs as well and assumed from past experience that roadways with homes on only one side would not be feasible. This is important because education for the development community might be needed to show that facing open space can create higher-valued properties (Arendt 1996), and though those properties are on just one side of the road, they are cost efficient. In both scheme ' $\mathrm{A}$ ' and scheme 'B', road length is about one thousand feet less than in the conventional development, as well as requiring significantly less paving material due to narrower width requirements.

Figure 6-1

Schofield Heights:

\section{Comparison of Design Approaches}

\begin{tabular}{|c|c|c|c|}
\hline Criterion & $\begin{array}{c}\text { Conventional } \\
\text { Design }\end{array}$ & Scheme A & Scheme B \\
\hline Parcel Acreage & 103.9 acres & 103.9 acres & 103.9 acres \\
\hline Number of House Lots & 50 lots & 55 lots & 55 lots \\
\hline Total Acreage Taken by Lots & $87.93 \mathrm{ac}(84.5 \%)$ & 4.41 ac $(42.7 \%)$ & 45.99 ac $(44.2 \%)$ \\
\hline Total Acreage for Right-of-Way & 10.58 ac $(10.2 \%)$ & 6.43 ac $(6.2 \%)$ & 5.49 ac $(5.3 \%)$ \\
\hline Total Acreage of Open-Space & 5.48 ac $(5.3 \%)$ & 53.15 ac $(51.1 \%)$ & 52.51 ac $(50.5 \%)$ \\
\hline Natural Undisturbed Open Space & 5.48 ac $(5.3 \%)$ & $45.08 \mathrm{ac}(43.4 \%)$ & $48.12 a c(46.3 \%)$ \\
\hline Created Open Space & 0 ac & 8.07 ac $(7.8 \%)$ & 4.39 ac $(4.2 \%)$ \\
\hline Total Linear Feet of Roads & $7,850 \mathrm{ft}$ & $6,990 \mathrm{ft}$ & $6,790 \mathrm{ft}$. \\
\hline Total Paved Acreage of Road Area & $6.17 a c^{*}$ & $3.86 \mathrm{ac}^{+5}$ & $3.29 \mathrm{ac}^{*-}$ \\
\hline Length of Trail Area & None & .91 miles & 1.0 miles \\
\hline Other Suggested Amenities & None & Mailroom, Gazebo & Mailroom, Gazebo \\
\hline
\end{tabular}


Some concern was also expressed regarding private ownership versus common ownership of areas such as open space and septic leachfields. And when asked if Charlton should consider allowing 20,000 square foot lots as long as they were attached to common septic systems, the response was split evenly, with half of the respondents saying yes, and half no. Clearly there are some questions that need to be answered before moving ahead with common septic leaching areas.

Encouragingly, most of the respondents thought that given the results, that the extra design work involved with this project was worth the effort; and surprisingly they considered the 10 percent bonus for the project adequate to compensate for the extra design work and trails. Something of a surprise, however, were the number of respondents who were unsure of the marketability of the two design schemes; which could have to do with inadequate information provided to them, or perhaps the uncertainty that comes with less-familiar designs. This last point, coupled with the concerns expressed about single-loaded roads, points to further research on the local level as to whether additional work with the development community would help increase awareness of the benefits of open-space subdivision designs.

\section{Recommendations}

Recommendations for improving Charlton's current "Flexible Development" regulations fall into four categories: changes in terminology; changes in locational requirements; changes in the workings of the design process; and changes in design and performance requirements. These changes would bring the town closer to its goal of preserving open space, and move the community forward in making more village-scaled subdivisions, as well as preserving useable wildlife habitat in the name of biodiversity.

\section{Changes in Terminology}

To begin, the term "flexible-development" does not adequately (nor succinctly) identify what this special type of subdivision is all about; what is "flexible" anyway, and 
why should any developer be interested in pursuing this approach? A typical alternative would be "cluster development", but this would actually be a worse title, as it tends to connote expanses of multi-family housing projects. This immediately (and erroneously) gets people concerned about their property values. A better term to call this option would be "Open-Space Development", which connotes country living as well as environmental sensitivity, a much more potent concept than is conjured up by "flexible-development".

\section{Changes in Locational Requirements}

Second, order to preserve habitat corridors around existing perennial streams and other ecologically sensitive areas, Open Space Development should be required in areas so designated on an overlay map, and optional in non-overlay residential areas.

\section{Changes in the Design Process}

Third, in the category of design process changes, it is recommended that the Charlton planning, conservation, health and engineering staff be involved (in an advisory basis) in the role of providing education and design assistance to the development community regarding open-space subdivisions. If the development community is to welcome this alternative, then the rewards have to be worth the perceived risks involved with going with a non-conventional design. Research may need to be done to show that open-space designs are marketable, and various maps should be provided so that the developer can undertaker the extra analyses involved with this approach. Staff help will also likely be needed with identification and preservation of wildlife habitats and corridors, both on-site and at the town level as well. That staff are already busy with other responsibilities is a given, but if better subdivision designs and deeper concerns about the environment are to become a reality, it is a responsibility of those with the knowledge to be part of the solution.

\section{Changes in Design and Performance Requirements}

Fourth, changes will need to be made in Charlton's zoning and subdivision regulations in order to proactively effect the preservation of open space for wildlife 
habitat, and to encourage the development community to use Flexible Development (now proposed to be "Open-Space Development") more often.

Referring to Appendix 'A', Charlton's Flexible Development Bylaw currently contains six sections: Purpose; Applicability; Standards; Open Space; Procedure; and Definitions. The following changes are recommended:

Section 5.7.1 (Purpose):

Should be changed to include the permanent preservation of contiguous open space for human enjoyment and to help sustain biological diversity.

\section{Section 5.7.2 (Applicability):}

Should be changed to include the encouragement of creating wildlife habitat corridors.

Section 5.7.3 (Standards):

-5.7.3.1 (Dimensional):

- Change minimum lot size to 30,000 sq.ft. in Agricultural District.

- Allow lots in R-40 zones to go to 20,000 sq.ft. if connected to a sewer system.

- Allow minimum frontage on cul-de-sac lots to be 50 feet as long as minimum lot width of 80 feet exists at the building setback line.

- Require a minimum building setback line of 20 feet and a maximum setback of 30 feet in Open-Space Developments.

- Allow lot frontage (up to 6 lots contiguously) on "common lanes", provided that each end of a lane intersects a public way, and further provided that each lane is maintained by a homeowner's association.

-5.7.3.2 (Clustering Requirement):

Existing wording is confusing, and should be substituted with a statement that creative groupings of houselots into small neighborhoods are to be considered where they are practical, and some 
examples of these groupings should be provided to encourage their usage.

\section{-5.7.3.3 (Access Requirement):}

Current wording is confusing, and should be changed to require access to open space area at readily identifiable areas (marked with signage if need be).

-5.7.3.4 (Open Space Requirement):

- Percentage of open space should be changed to between 40 percent and 50 percent, depending on whether proposed subdivision is in Open Space Overlay District.

- Add clause about "wherever practical, open space shall be contiguous to other protected open space and/or bodies of water".

- Open space developments in the Open Space Overlay District should be required to have contiguous open space areas, and should also have Town of Charlton staff assistance during the design process, for appropriate consideration of wildlife corridors.

\section{-5.7.3.5 (Bonus Allowance)}

Should be changed so that in the Overlay District, the maximum bonus percentage would be 10 percent more developable lots, as long as the remaining open space was a minimum of 50 percent. In areas where open space development is optional, the developer should be allowed to have of bonus of up to 20 percent more lots, as long as the total percentage of open space does not fall below 40 percent of the original parcel, and as long as additional amenities are provided, such as stone walls, mail-rooms, playgrounds, etc.

[This "incentive" open space development option could have the added benefit initially of encouraging residential development away from 
established wildlife corridor areas until much later in Charlton's buildout process]

Section 5.7.4 (Open Space):

No changes are recommended.

Section 5.7.5 (Procedure):

Should be changed to require that a conventional development "yield plan" of the parcel be drawn (with all buildable lots containing a minimum of two-thirds upland), so that the "base" number of lots to be proposed can be determined.

Section 5.7.6 (Definitions):

Should provide definition for "Open Space Development".

Additionally, sidewalks in Open Space Developments should be required to provide access to the common open space areas for as many dwellings as practical. Lastly, Charlton's Subdivision Regulations should be changed to add a separate section for Open Space Development, so that requirements for this type of design can be understood as a whole. 


\section{Ch. 7}

\section{Conclusion}

This study has provided a deeper understanding of the inter-connectedness and inter-dependencies between humanity, wildlife, and the natural environment. It has also shown that the greatest obstacle to our understanding and acceptance of these interdependencies is our anthropocentric frame of reference. That ultimately humans depend on the environment to survive is known intellectually, but that knowledge is cold comfort when we think about how well this concept is accepted economically and politically. The answers to the conundrum of humans and the environment lie either in physical-ethical constructs such as sustainability and carrying capacity, or in the major collapse of ecosystems and species extinction.

The preservation of contiguous open space in support of biodiversity is a valuable undertaking. Wildlife species are a necessary part of our ecosystems, representing the living library of the planet's genetic heritage. It cannot be assumed that wildlife corridors will continuously exist as we develop further and further into remaining open land, fragmenting habitat and weakening long-term species viability. We need to be proactive about preserving biodiversity, and this study has offered a basis for accomplishing this at the local level.

The regional (landscape) level is the most appropriate level in conservation biology for preserving biodiversity, but today in Massachusetts that level of planning does not yet exist. This is due to practical reasons (accurate data isn't available) as well as political reasons (because each community in Massachusetts is a small kingdom unto itself, and doesn't have to preserve areas it doesn't want to). One possible solution in the interim is for municipalities within bioregions to work together on their own to identify wildlife corridors, and to then individually craft development bylaws that collectively will protect 
these areas for the future. As identified in this study, local community staff support should be used to identify areas where open space development is mandatory for subdivision development, and should be involved in the design of these projects in order that preservation of useable wildlife corridors can be accomplished.

As was shown in the Schofield Heights design project, contiguous areas of open space can be preserved in a way that is sensitive to the protection of wildlife habitat, and at the same time provide people living in this community with tangible connections and use of that open space. Connections of people with one another could be improved upon as well by reducing lot widths, lot areas, and front building setbacks to a more village-like scale, while at the same time meeting septic system requirements.

That all these "connections" need to be made deliberately has provided the most important learning of this project. People have always intervened in natural processes, and this study has been a small testament that we must continue doing so. Because we are capable of altering the environment on a massive scale, however, we now need to approach nature as stewards of its future, in order to be sustained. May our timing be good. 


\section{References}

Arendt, Randall, Elizabeth A Brabec, et al. 1994. Rural By Design: Maintaining Small Town Character. Chicago: American Planning Association.

Arendt, Randall G. 1996. Conservation Design for Subdivisions. Washington, DC: Island Press.

Beatley, T. 1994. Habitat Conservation Planning:Endangered Species and Urban Growth. Austin. Texas: University of Texas Press.

Beatley, Timothy. 1994. Ethical Land Use: Principles of Policy and Planning. Washington, D.C. John Hopkins University Press.

Benyus, Janine M. 1989. The Field Guide to Wildlife Habitats of the Eastern United States. New York: Simon \& Schuster.

Berry, Wendell. 1995. Another Turn of the Crank. Washington, DC: Counterpoint.

Bickford, WE and U.J. Dymon, eds. 1990. An Atlas of Massachusetts River Systems: Environmental Designs for the Future. Amherst, MA: Univ. of Massachusetts Press.

Blankenship, K. 1996. Streamside Forests: Keys to the Living Landscape. American Forests Spring 1996: 13-39.

Boston Globe. 1997. 'Pox" Strikes Florida's Coral Reef: Mysterious Disease Wipes Out 80 Percent of Animals in Some Spots in Year. Boston Globe February 16, 1997: p. A8

Brower, David R. and Steve Chapple. 1995. Let the Mountains Talk, Let the Rivers Run: A Call to Those Who Would Save The Earth. San Francisco: Harper Collins.

Cherfas, J. 1994. How Many Species do we Need? New Scientist $143,1937: 36-41$.

Chiras. Daniel D. 1992. Lessons from Nature: Learning to Live Sustainably on the Earth. Washington, D.C. Island Press.

Cronon, William. 1983. Changes in The Land: Indians, Colonists, and the Ecology of New England. New York: Hill and Wang.

Croonquist, M.J. and R.P. Brooks. 1993. Effects of Habitat Disturbance on Bird Communities in Riparian Corridors. Journal of Soil and Water Conservation 48, 1: 65-9.

Daly, Herman E. and John B Cobb,Jr. 1994. For the Common Good: Redirecting the Economy Toward Community, the Environment, and a Sustainable Future. Boston: Beacon Press.

Desbonnet. Alan. Pamela Pogue, et al. 1994. Vegetated Buffers in the Coastal Zone: A Summary Review and Bibliography. Naragansett. RI: Coastal Resources Center.

Easterbrook. Gregg. 1995. A Moment on the Earth: The Coming Age of Environmental Optimism. New York: Viking Penguin.

Ehrlich, P.R. and AH Ehrlich. 1981. Extinction: The Causes and Consequences of the Disappearance of Species. New York, NY: Random House. 
Epenshade, EB and J.L. Morrison, eds. 1978. Goode's World Atlas, 15th Edition. Chicago: Rand McNally \& Co.

Farber, S. 1991. Intergenerational Transfers and Ecological Sustainability. In Ecological Economics: The Science and Management of Sustainability. Costanza R. ed.New York: Columbia University Press.

Fogg, George E. 1990. Park Planning Guidelines. Third ed. Alexandria, VA: National Recreation and Park Association.

Goldsmith, Edward, Nicholas Hildyard, et al. 1990. Imperiled Planet: Restoring Our Endangered Ecosystems. Cambridge, Massachusetts: MIT Press.

Gore, Al. 1992. Earth in the Balance: Ecology and the Human Spirit. New York: Houghton Mifflin.

Grumbine, R.E. 1994. Wildness, Wild Use, and Sustainable Development. Environmental Ethics 16, 1

Haeuber, R. 1996. Setting the Environmental Policy Agenda: The Case of Ecosystem Management. Natural Resources Journal 36, 1: 1-27.

Holt, R.D., G.R. Robinson, and M.S. Gaines. 1995. Vegetation Dynamics in an Experimentally Fragmented Landscape. Ecology 76, 5: 1610-24.

Jarvis, Frederick D. 1993. Site Planning and Community Design for Great Neighborhoods. Washington, DC: Home Builder Press.

Kellert. Stephen R and Edward O. Wilson, eds. 1993. The Biophilia Hypothesis. Washington, DC: Island Press.

Kendig, Lane. 1980. Performance Zoning. Washington, DC: Planner's Press, American Planning Assoc.

Kim, K.C. and RD Weaver. 1994. Biodiversity and Landscapes: A Parodox of Humanity. Cambridge, England: Cambridge Univ. Press.

Krueckeberg, D.A. 1995. The Difficult Character of Property: To Whom Do Things Belong? Journal of the American Planning Association 61. 3: 301-9.

Listokin, David and Carole Walker. 1989. The Subdivision and Site Plan Handbook.

Marsh, William M. 1991. Landscape Planning: Environmental Applications. 2nd ed. New York: John Wiley \& Sons.

Massachusetts. 1994. 310 CMR 10.00: Wetlands Protection Act Regulations.

Massachusetts. 1995. ALM GL c. 131: Inland Fisheries and Game. sec. 40. Protection of Flood Plains, Seacoasts. and Other Wetlands; Definitions.

Massachusetts. 1995. 304 CMR 11.00: Forest Cutting Practices.

Massachusetts. 1996. Acts of 1996: The Rivers Protection Act. Ch. 258. The Rivers Protection Act.

Mauritis la Riviere, J.W. 1989. Threats to the World's Water. In Managing Planet Earth: Readings from Scientific American. AnonymousNew York, NY: W.H. Freeman \& Co. 
McHarg. lan L. 1991. Design With Nature. New York: John Wiley \& Sons.

McKibbon. B. 1995. An Explosion of Green. Atlantic Monthly May 1995: 61-83.

Meadows, Donella H., Dennis L Meadows, et al. 1992. Beyond the Limits: Confronting Global Collapse, Envisioning a Sustainable Future. Post Mills, Vermont: Chelsea Green Publishing.

Merchant, Carolyn. 1992. Radical Ecology:The Search for a Livable World. London: Routledge.

Morrison, M.L., BG Marcot, et al. 1992. Wildlife-Habitat Relationships: Concepts and Applications. Madison, Wisconsin: Univ. of Wisconsin Press.

Northern Forest Lands Council. 1994. Finding Common Ground: Conserving the Northern Forest. Concord, New Hampshire: Northern Forest Lands Council.

Noss. R.F. 1997. Issues of Scale in Conservation Biology. In Conservation Biology: The Theory and Practice of Nature Conservation, Preservation, and Management. Fiedler PL, Jain SK. eds.New York, NY: Chapman and Hall.

Noss. Reed F. and Allen Y Cooperrider. 1994. Soving Nature's Legacy: Protecting and Restoring Biodiversity. Washington, D.C. Island Press.

Orians, G.H. 1995. Thought for the Morrow: Cumulative Threats to The Environment. Environment 37, 7: 6-19.

Peskin. H.M. 1991. Alternative Environmental and Resource Accounting Approaches. In Ecological Economics: The Science and Management of Sustainability. Costanza R, ed.New York: Columbia University Press.

Piel, G. 1992. Only One World:Our Own to Make and Keep. New York: W.H.Freeman.

Postel, S. 1994. Carrying Capacity: Earth's Bottom Line. In State of The World 1994: A Worldwatch Inststute Report on Progress Towards a Sustainable World. Brown L, et al. eds.

Povilitis, T. 1995. Changes in Habitat Threaten Biodiversity. Forum For Applied Research and Public Policy Spring 1995: 97-100.

Ramsey, Meredith. 1996. Community, Culture, and Economic Development: The Social Roots of Local Action. Albany, NY: State University of New York Press.

Rowe. Peter G. 1991. Making a Middle Landscape. Cambridge: MIT Press.

Steiner, Frederick. 1990. The Living Landscape: An Ecological Approach to Landscape Planning. New York: McGraw-Hill.

The Global Tomorrow Coalition. 1989. A Guide to "Our Common Future". Washington, DC: Global Tomorrow Coalition.

Tilman. D., R.M. May, C.L. Lehman, et al. 1994. Habitat Destruction and the Extinction Debt. Nature 371, 6492: 65-6.

Town of Charlton. 1989. Subdivision Regulations. Charlton, MA: Planning Board.

Town of Charlton. 1997. Zoning Bylaw. Amended to May $1997 \mathrm{ed}$. Charlton, MA: 
United Nations Conference on Environment and Development. 1993. Agenda 21: Programme of Action for Sustainable Development. New York, N.Y. United Nations Dept. of Public Information.

Wilson, B.C. 1995. The Mianus Watershed Bioregional Planning Project. Places: A Forum of Environmental Design 9, 3: 18-21.

Wilson, E.O. 1989. Threats to Biodiversity. In Managing Planet Earth: Readings from Scientific American. Scientific American, ed.New York: W.H. Freeman.

Wilson, E.O. 1992. The Diversity of Life. Cambridge, MA: Harvard University Press.

World Commission on Environment \& Development (WCED). 1987. Our Common Future. Oxford, NY: Oxford University Press.

World Resources Institute. 1992. Biodiversity in Freshwater Systems. Internet Website: www. wri.org; World Resources Institute.

Yaro, Robert D., Randall G Arendt, et al. 1993. Dealing with Change in the Connecticut River Valley: A Design Manual for Conservation and Development. Amherst, Massachusetts: Lincoln Institute of Land Policy. 


\section{Appendix A}

\section{Charlton's Existing Flexible Development Bylaw}

\subsection{Flexible Development}

\section{7 .1 Purpose}

The purpose of the flexible development option is to provide for the most efficient use of services and infrastructure, to maintain the Town's traditional New England rural character and land use patterns and to encourage the permanent preservation of open space.

\section{7 .2 Applicability}

Flexible development shall be permitted on parcels of ten (10) acres or more in A, R-40 and R-SE districts upon the issuance of a special Permit for Flexible Development from the Planning Board upon a finding that the proposed flexible development will be superior to a conventional subdivision plan in: allowing for greater flexibility and creativity in the design of residential developments; encouraging the permanent preservation of open space, agricultural land, forests and woodland, historic or archaeological sites, or other natural resources; maintaining the Town's traditional New England rural character and land use patterns in which small villages contrast with open spaces, farmland and forests; preserving scenic vistas; providing for the most efficient use of municipal and other services; preserving unique and significant natural, historical and archaeological resources; and encouraging a less sprawling form of development, but not to the extent that such development will visually and environmentally overwhelm the land.

\section{7 .3 standards}

5.7.3.1 Building lots within flexible developments shall conform to the following standards:

\begin{tabular}{|c|c|c|c|c|c|c|}
\hline Zoning & $\begin{array}{c}\text { Min. Lot } \\
\text { Area }\end{array}$ & & & Setba & & $\begin{array}{c}\text { Max. } \\
\text { Building }\end{array}$ \\
\hline District & (sq. ft. $)$ & Erontage & Eront & Side & Rear & Coverage \\
\hline A & 45,000 & $100^{\prime}$ & $30^{\prime}$ & $15^{\prime}$ & $30^{\prime}$ & 308 \\
\hline$R-40$ & 30,000 & $100^{\prime}$ & $30^{\circ}$ & $15^{\prime}$ & $15^{\prime}$ & 308 \\
\hline$R-S E$ & $30.000^{1}$ & $100^{\circ}$ & $30^{\prime}$ & $15^{\prime}$ & $15^{\prime}$ & 308 \\
\hline
\end{tabular}

${ }^{1}$ Building lots may contain 20,000 square feet if connected to a sewer system.

5.7.3.2 The lots within the flexible development used for residential structures shall be grouped, where each lot shall be contiguous. Every group shall be separated from every other group within any flexible development by a distance determined by the Planning Board.

5.7.3.3 A strip of permanently restricted open space, the width of which shall be at the discretion of the Planning Board, shall be 
provided between every group and the exterior property lines of the flexible development parcel.

5.7.3.4 A minimum of 258 of the land area in the flexible development shall be permanently restricted open space and shall be suitable for recreational, agricultural or cultural uses. The Planning Board may require that at least fifty (50) percent of the permanently restricted open space shall be free from wetlands as defined in the Wetlands Protection Act. However, such open space may contain more than $50 \%$ wetlands if the additional open space consists of bodies of water.

5.7.3.5 The number of building lots proposed may exceed the number that would normally be allowed by a conventional subdivision plan in full conformance with zoning, subdivision regulations, health codes, wetlands bylaws and other applicable requirements by 108 if the planning Board finds that the character of the surrounding area would not be adversely affected thereby and that all other requirements of this section are met.

5.7.3.6 No lot shown on an approved flexible development plan shall be further subdivided and the plan shall be so noted. Relocation of lot lines, street layout and open space layout may be allowed after approval, provided that no increase in the number of building lots results thereby and provided further that approval of the Planning Board is given. If the Board determines that a proposed revision constitutes a substantial change, a public hearing shall be held at the expense of the applicant.

5.7.3.7 Streets constructed within the flexible development shall conform to the applicable requirements of the Rules and Regulations Governing the Subdivision of Land.

\section{7 .4 open space}

5.7.4.1 The open space to be permanently restricted shall be conveyed to one of the following:

a. The Town of Charlton for conservation, recreation, agricultural or park purposes if accepted by a Town Meeting; b. A non-profit organization the principal purpose of which is the conservation of open space; c. A corporation or trust owned or to be owned by the owners of lots or residential units within the flexible development.

The Board may also require that scenic, conservation or historic easements be deeded to the Town or other non-profit organization.

5.7.4.2 The special permit shall state any restrictions on the use of the open space. Where such land is not conveyed to the Town, it shall be covered by a restriction, enforceable by the Town or a non-profit organization, running with the land, which provides that such land shall be used only for the purposes specified in the special permit. Such restrictions may provide easements for underground utilities but they shall not permit wells or septic systems upon the land. The open space may not be developed for uses accessory to the residential use such as parking or roadways. Wherever practical, the open space shall be contiguous to other protected open space or bodies of water. 
5.7 .4 .3 If the open space subject to the restrictions established by the special permit is to be owned by a corporation or trust in accordance with 5.7.4.1 c., maintenance of the common land shall be permanently guaranteed through the establishment of an incorporated homeowners association which provides for mandatory membership by the lot or unit owners, assessments for maintenance expenses, a general liability insurance policy covering the open space, and a lien in favor of the Town of Charlton in the event of the lack of maintenance. The terms of the lien shall provide that the Town may, if it determines that required maintenance has not been accomplished as required by the conditions of the special permit, perform the required maintenance and assess the members of the corporation or trust, or the corporation or trust itself, for the cost of such maintenance. Copies of the documents creating the corporation or trust of the general liability insurance policy, and of the lien, shall be submitted to the Planning Board for review and shall be recorded in the Registry of Deeds, in the form and with content as approved by the Planning Board, as a condition of the special permit.

5.7.4.4 The open space shall not be leased, sold or used for purposes other than those authorized by the special permit. Any proposed change to the use of the open space shall be approved by a majority of the Planning Board present and voting, provided that: the proposed use is consistent with the intent of this section, and it will not adversely impact abutters and the use of surrounding open space by bright lights, noise or other nuisances. The Board may impose conditions on such proposed uses.

\section{7 .5 Erecedure}

5.7.5.1 A pre-application meeting with the Planning Board and other relevant Boards for review and discussion of a preliminary or conceptual plan is recommended prior to a formal submission of an application for a special permit. Preliminary sketches of a flexible development plan and a conventional subdivision plan are encouraged to be submitted.

5.7.5.2 No application shall be deemed complete, nor shall any action be taken, until all required materials have been submitted. Plans and other submission materials conforming to the Planning Board's adopted "Procedures for Applications for a Special Permit for Flexible Development", as filed with the Town Clerk, shall be submitted to the Planning Board and Town Clerk as required by such Procedures.

5.7.5.3 The Planning Board shall, within fifteen (15) days of submission, distribute one (1) copy of the submission materials each to the Conservation Commission, Board of Health, Sewer Commission, Building Inspector, Fire Department and Board of Selectmen for review and comment. The Planning Board shall not take final action on the plan within thirty-five (35) days of such distribution unless such comments are sooner received.

5.7.5.4 The Planning Board shall hold a public hearing and make its decision in accordance with applicable provisions of M.G.L. $\mathrm{Ch}$. 40A unless otherwise required by Massachusetts law; the Board shall hold a public hearing within sixty-five (65) days of the filing of the application with the Town Clerk; the Board shall file its decision with the Town Clerk within ninety (90) days following 


\begin{abstract}
the date of the public hearing; and the granting of a special permit shall require a four-fifths (4/5) vote of the Planning Board. The cost of advertising the hearing and notification of abutters shall be borne solely by the applicant. The time limits hereunder may be extended by written agreement between the petitioner and the Planning Board and any such agreement shall be filed with the Town clerk.
\end{abstract}

5.7.5.5 The granting of a special Permit for Flexible Development shall not be construed as definitive subdivision approval under the Subdivision control Law. The approval of a definitive subdivision plan showing a flexible development shall not be construed as the granting of a special permit. However, the applicants are encouraged to request a simultaneous public hearing for both plans, if required. 5.7.5.6 The special permit shall not be valid until recorded in the Registry of Deeds and no work may commence until evidence of such recording has been received by the planning Board and the Building Inspector. Such recording shall be the responsibility of the petitioner.

\title{
5.7 .6 Definitions
}

The following terms shall have the following meanings for the purposes of this section:

Elexible Development: A residential development in which single family dwelling units are clustered together into one or more groups on the lot and the groups are separated from each other and adjacent properties by permanently protected open space. 


\section{Appendix B}

\section{More Information About the Quinebaug \& Erench River Basins \\ Source: Bickford, WE and U.J. Dyman, 1990. An Atlas of Massachusens River Systems: Environmental Designs for the Future. Amhers, MA: Univ. of Massachusets Press, pp. 48-9.}

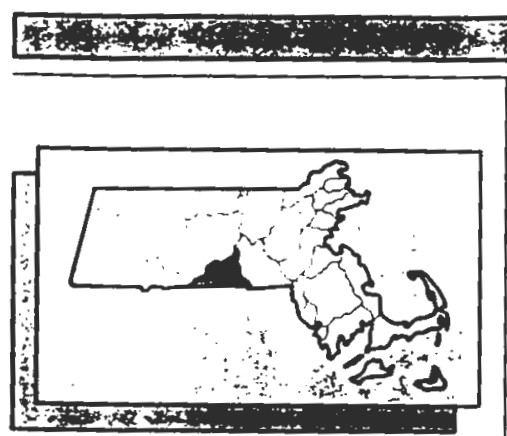

River Basin:

Quinebaug and French

Total Drainage Arex: 1,474 sq. mi

Drainage Area in MA: 231 \&q. mi.

Source of River.

Quinebaug: brooks in wearers

Brimfield and Wales

French: ponds of Leicester and

Spencer

Mouth of Rtrer:

Quinebuug: Themes Rtrer

French: Themes River

Total River Length:

Quinebaug: $65 \mathrm{mi}$

French: $20.6 \mathrm{mi}$

River Length in MA:

Quinebrug: $18.7 \mathrm{mi}$

Freach: $14.4 \mathrm{mi}$

Major Tribucariex: Cady Brook,

Little Rtver, Mill Brook

Acres of Ponds, Lakes, Reservolrs:

5,999

Hydropower Fucllitien:

Quinebaug: 2; $168 \mathrm{kw}$

French: 1; $200 \mathrm{kw}$

Wastewater Dischurgex:

Musicipal Treatment Plent:

Quinebaug 3; French 2

Featurex: Weboter Lake, Brimfield

State Forest, Old Sturbridge

Village, Weatville Leke, Eest

Brimfield Lake, Hodgea Village

Dam, Buffumville Lake

Rare Species:

Plants: autumn coral root, purple clematis

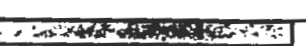

\section{Quinebaug \& French River Basins}

The Quinebaug River and the French River are both tributaries of the Thames River, which they join in the state of Connecticut. For their size, these river basins have many acres of lakes and ponds. The most notable lake is on the French River. It's one of the largest natural lakes in the state and has the longest name as well: Lake Chargoggagoggmenchaugagoggchaubunagungamuagg (to the native Americans it means "you fish on your side we fish on our side and nobody fishes in the middle.") Today it is known as Webster Lake. The basin's terrain has many hills cresting above 1,000 feet, but is geology is not particularly unusual. Therefore, the watershed does not harbor meny rare species of pleats or animels.

Both rivers were altered by federal flood control dams after major hoods in 1955. Water quality problems exist due to previous and current industrial discharges and because of low flows and sedimentation in the impoundments. Major projects se now in progress to remedy these problems. The Quinebaug, which is stocked with brook, brown and rainbow trout, offers good sport fishing. The Freach offers pleasunt, winding, slow waters, and particularly lovely scenery when fall color decorates the banks.

Both rivers were the sites of factories and mills during the early 1800 's. Sturbridge Village, the historic reconstruction of the period, demonstrates several water powered mills which still use water from the Quinebaug today.

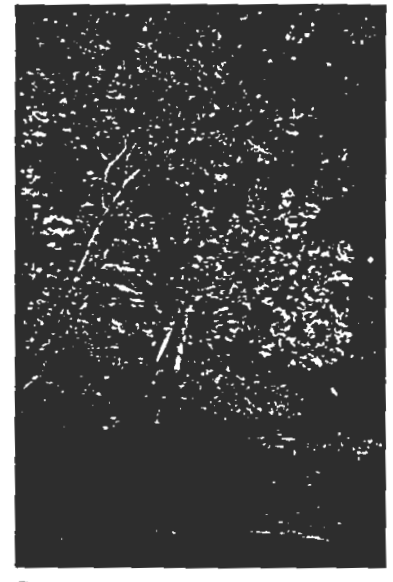

River in sutumn

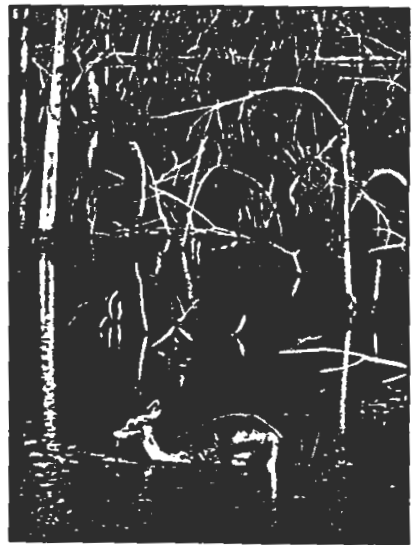

Whitetell deer 


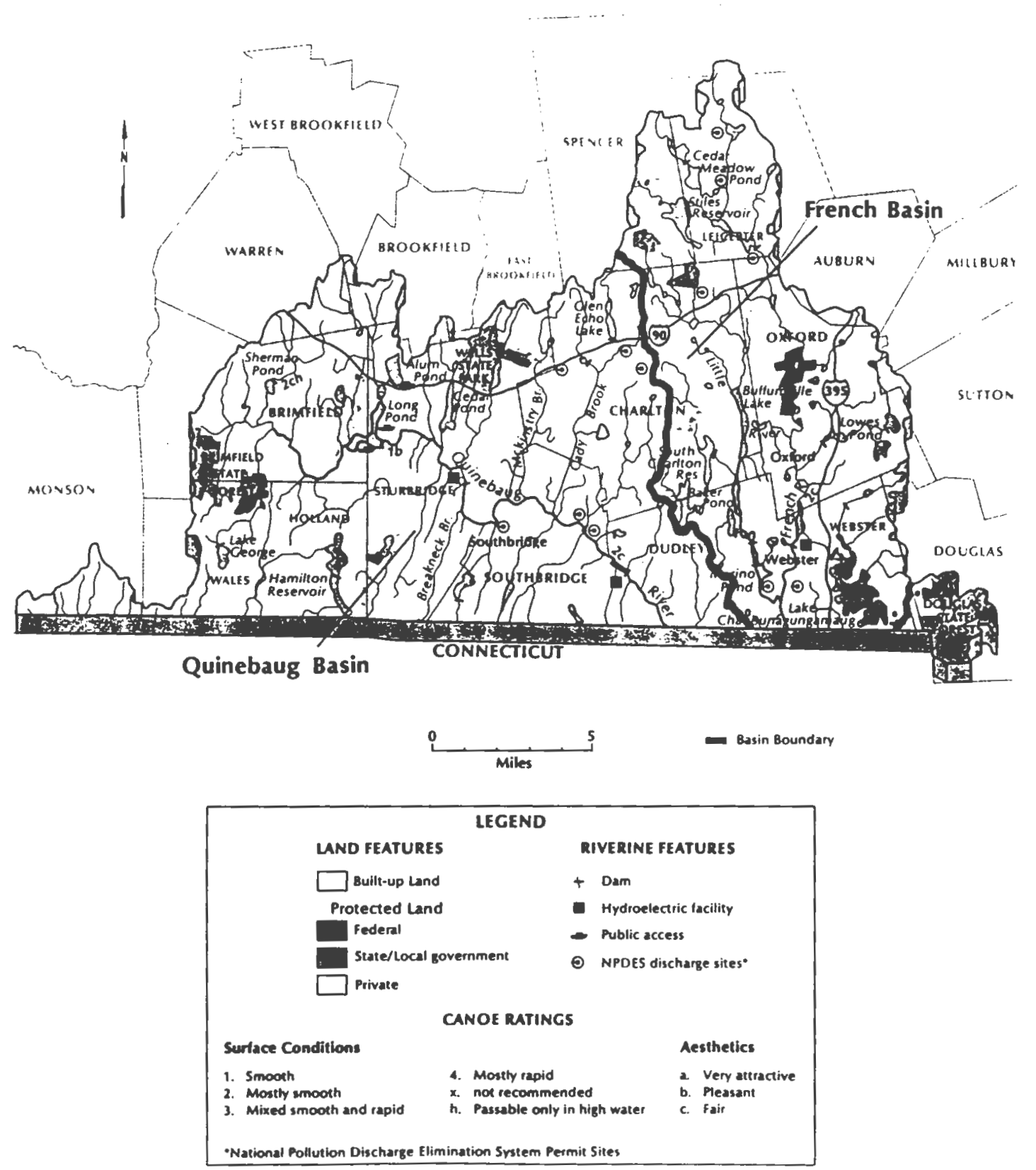




\section{Appendix C}

\section{Schofield Heights - Analysis Phase Maps}

Map 1 Aerial Photograph of Project Area

Map 2 USGS Quad Map of Project Area

Map 3 Available Groundwater

Map 4 Flood Plains in Charlton

Map 5 Charlton Soil Limitations Map

Map 6 Estimated Rare Wildlife Habitats in Charlton

Map 7 Charlton Agricultural Land

Map 8 Designated Scenic Areas in Charlton

Map 9 Characteristic Charlton Geological Features

Map 10 Charlton Cultural, Archaeological, + Historic Areas

Map 11 Configuration of Parcels Surrounding Project Area 


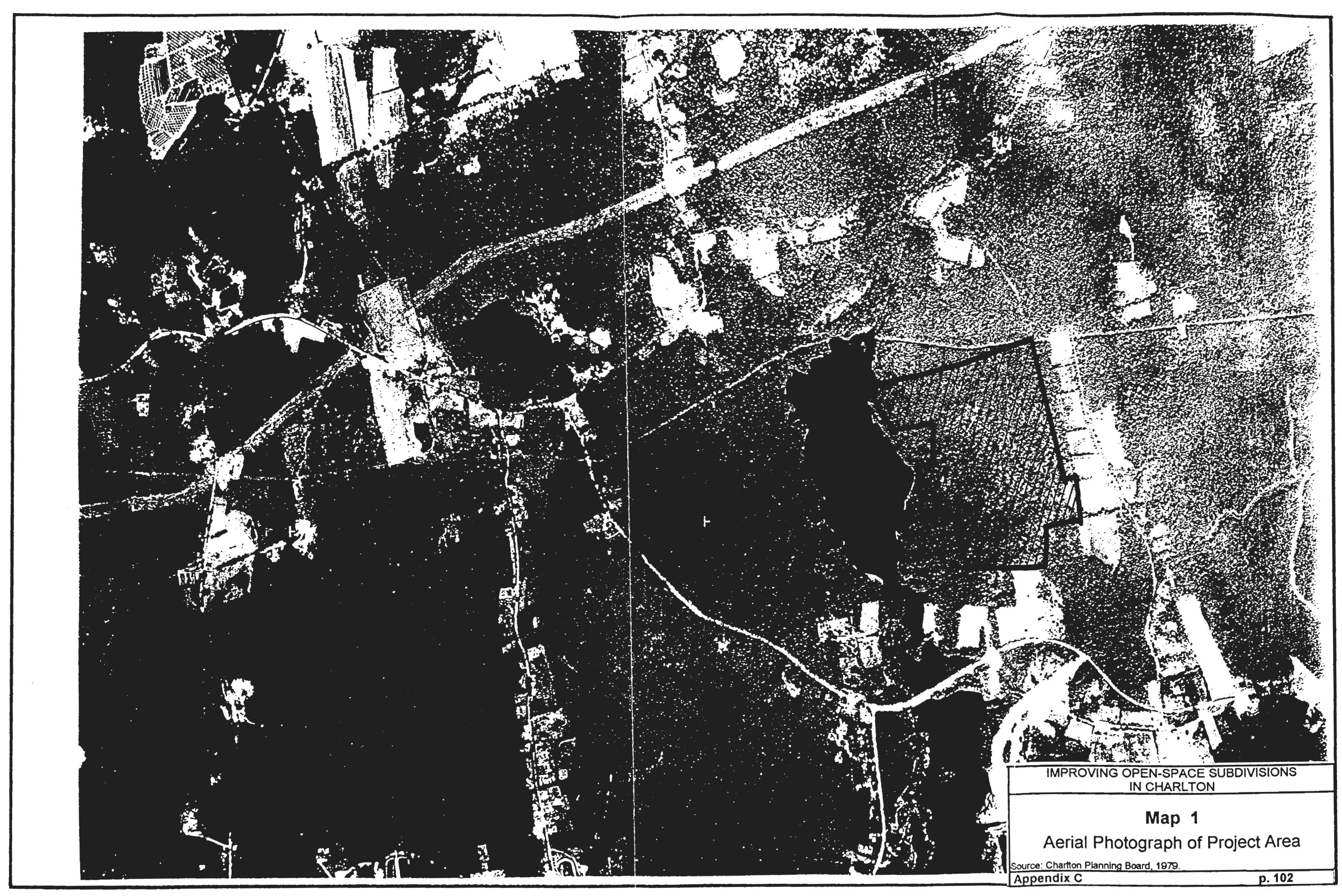




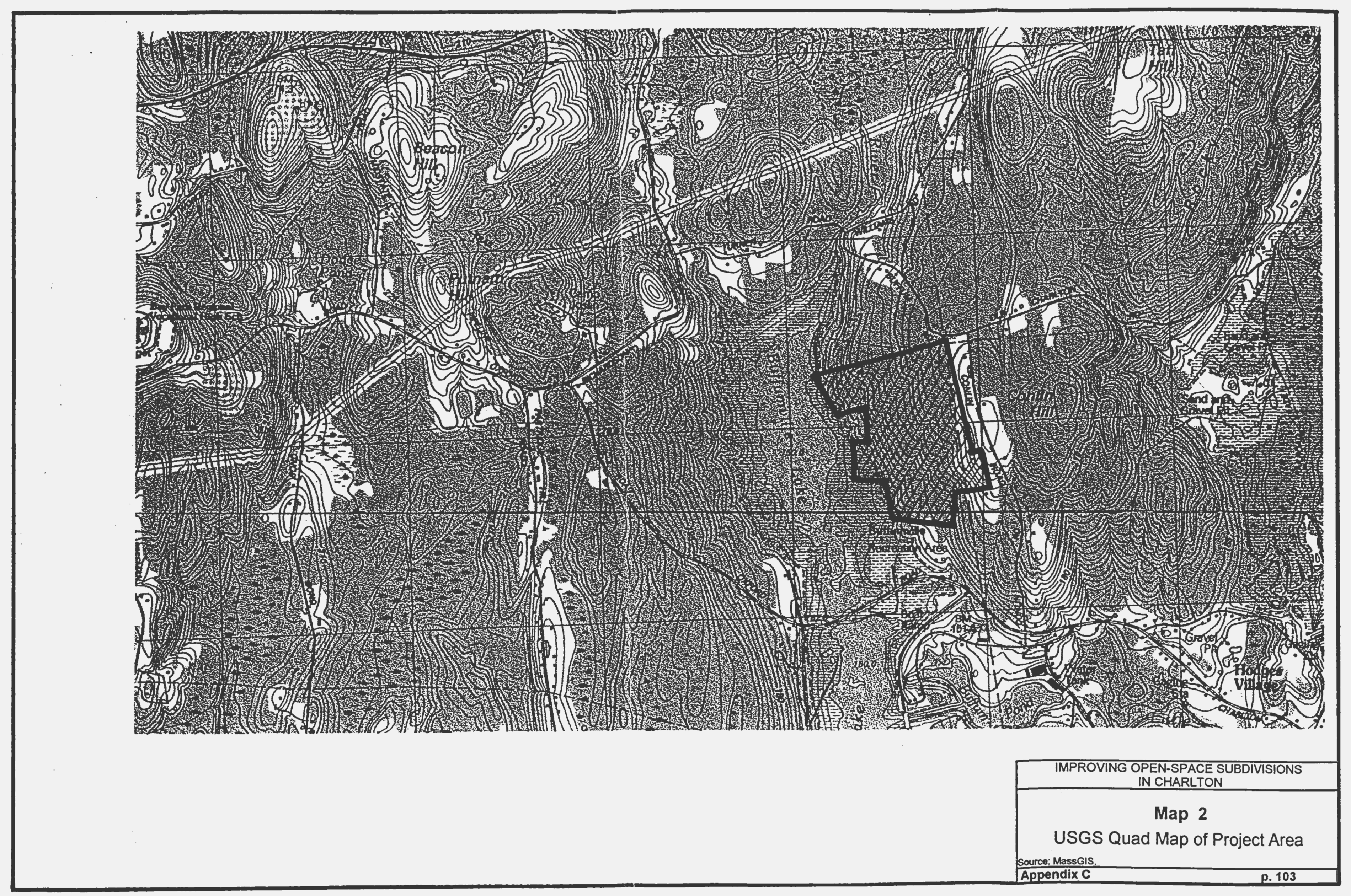




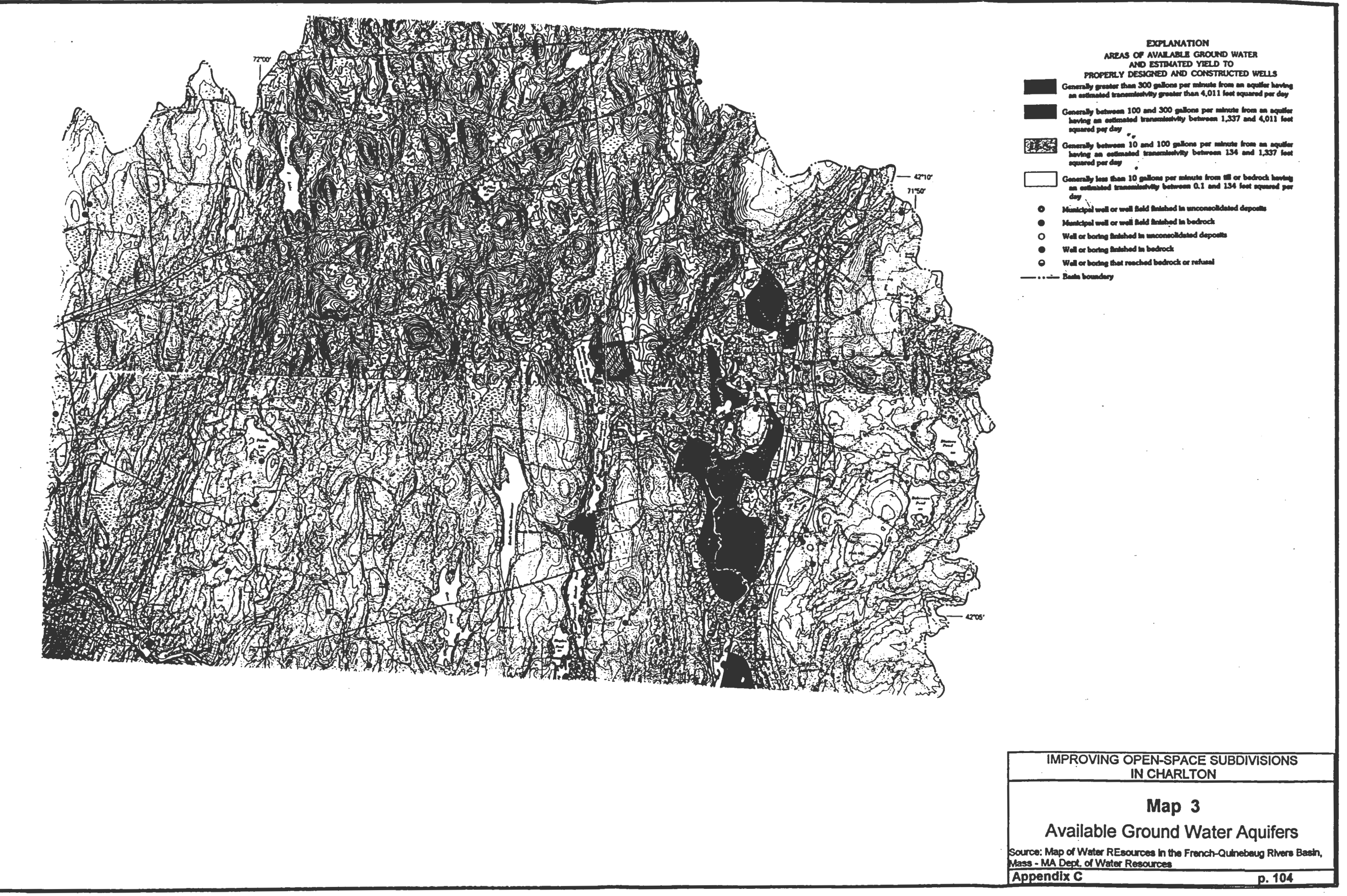




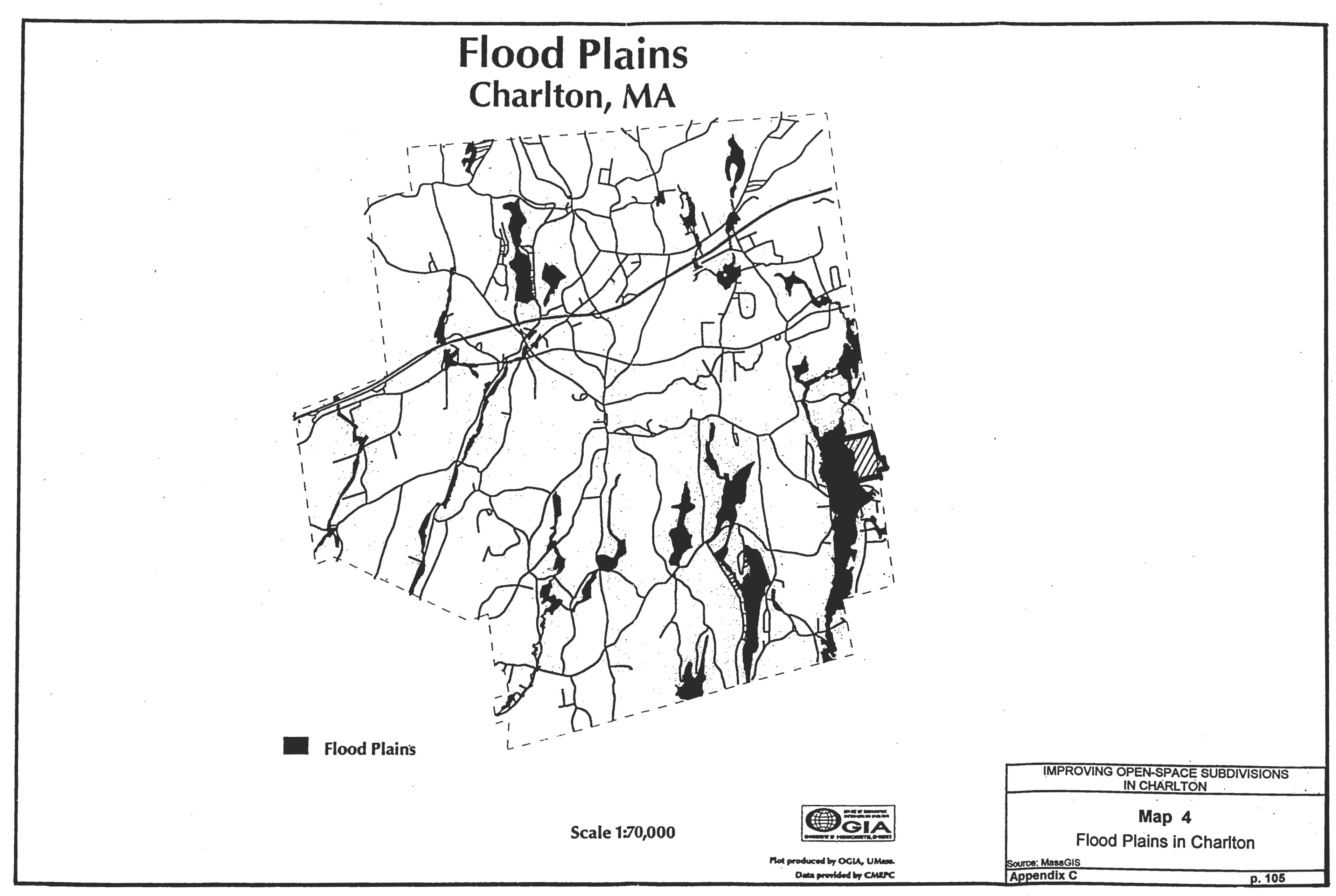




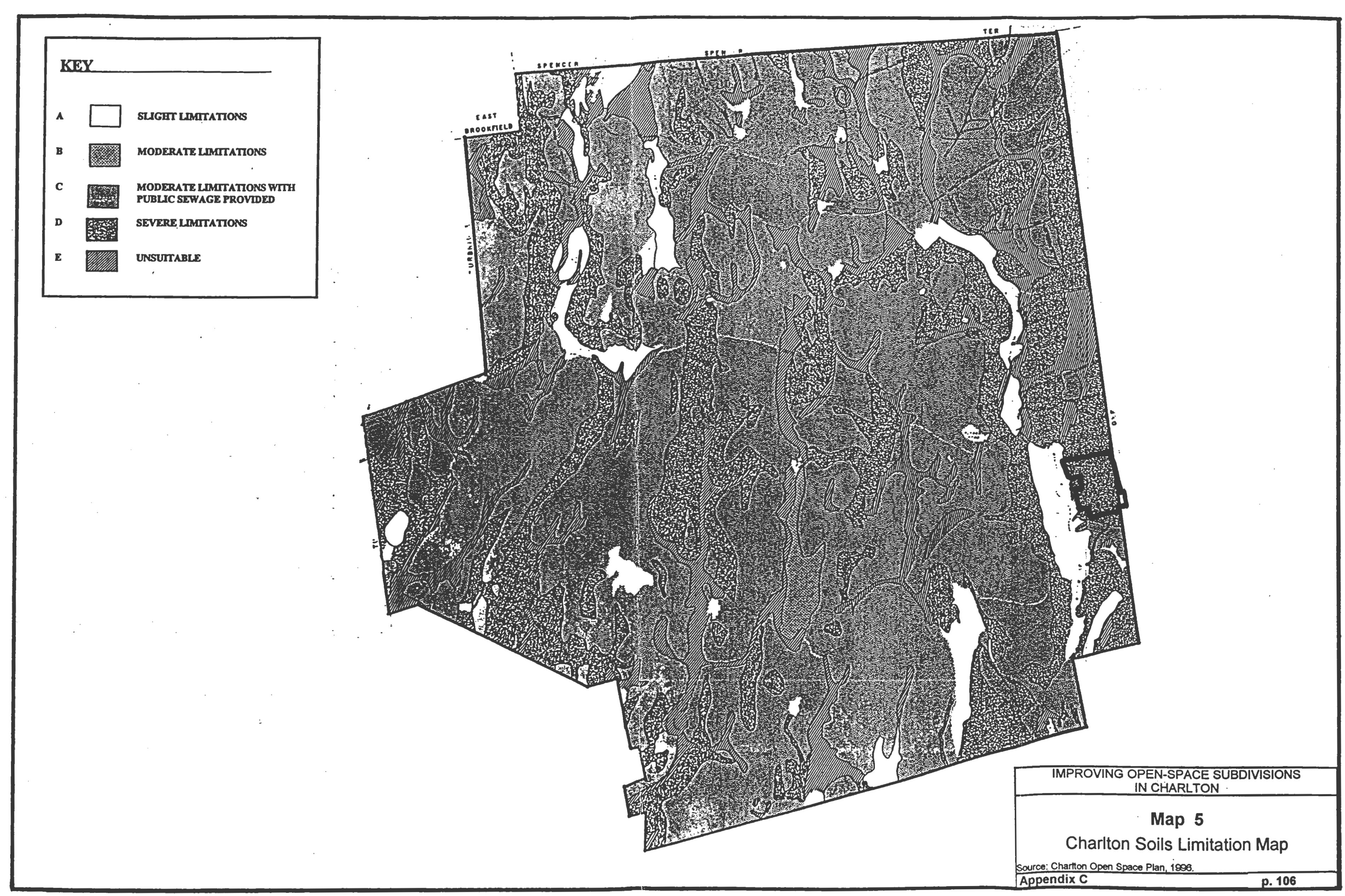




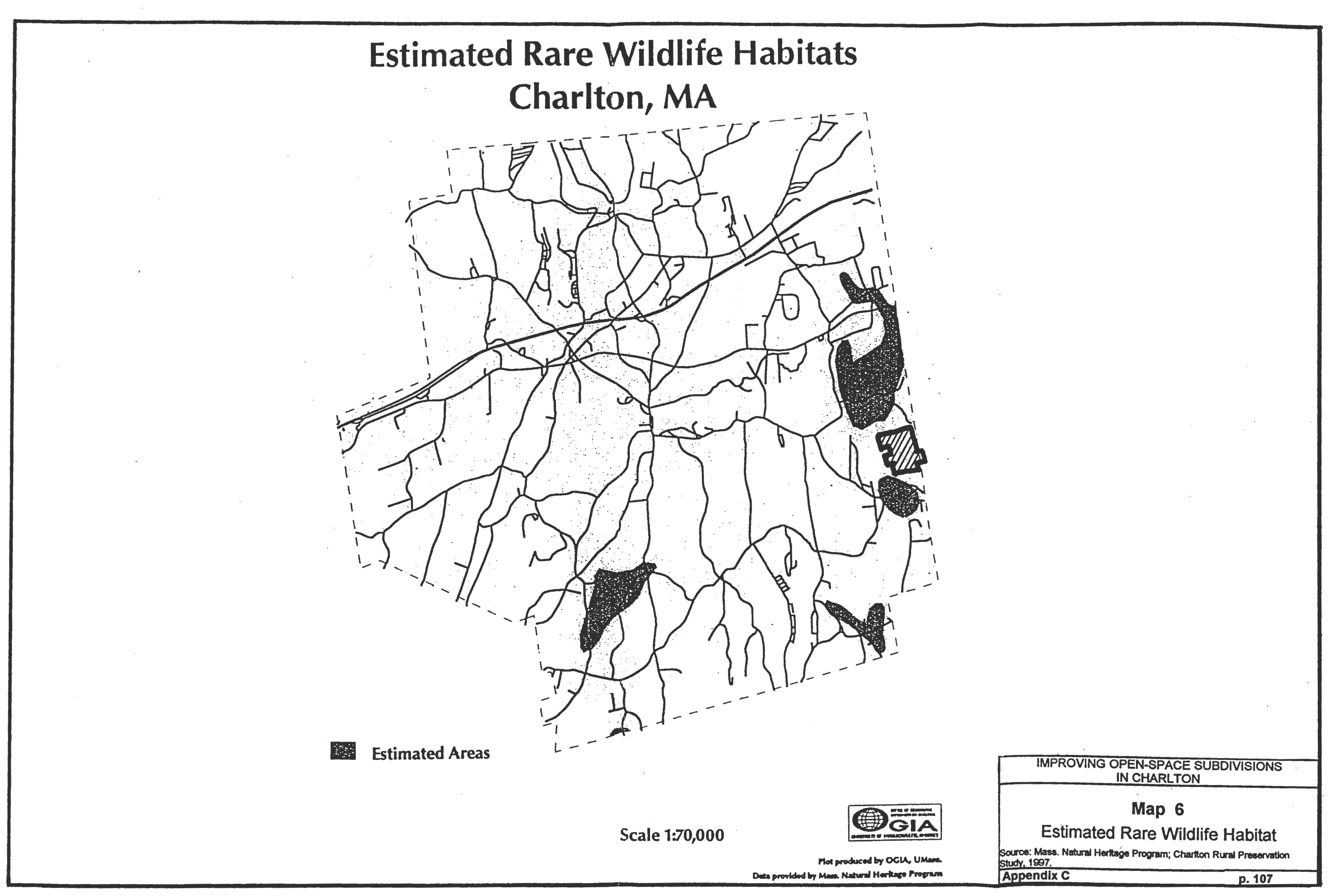




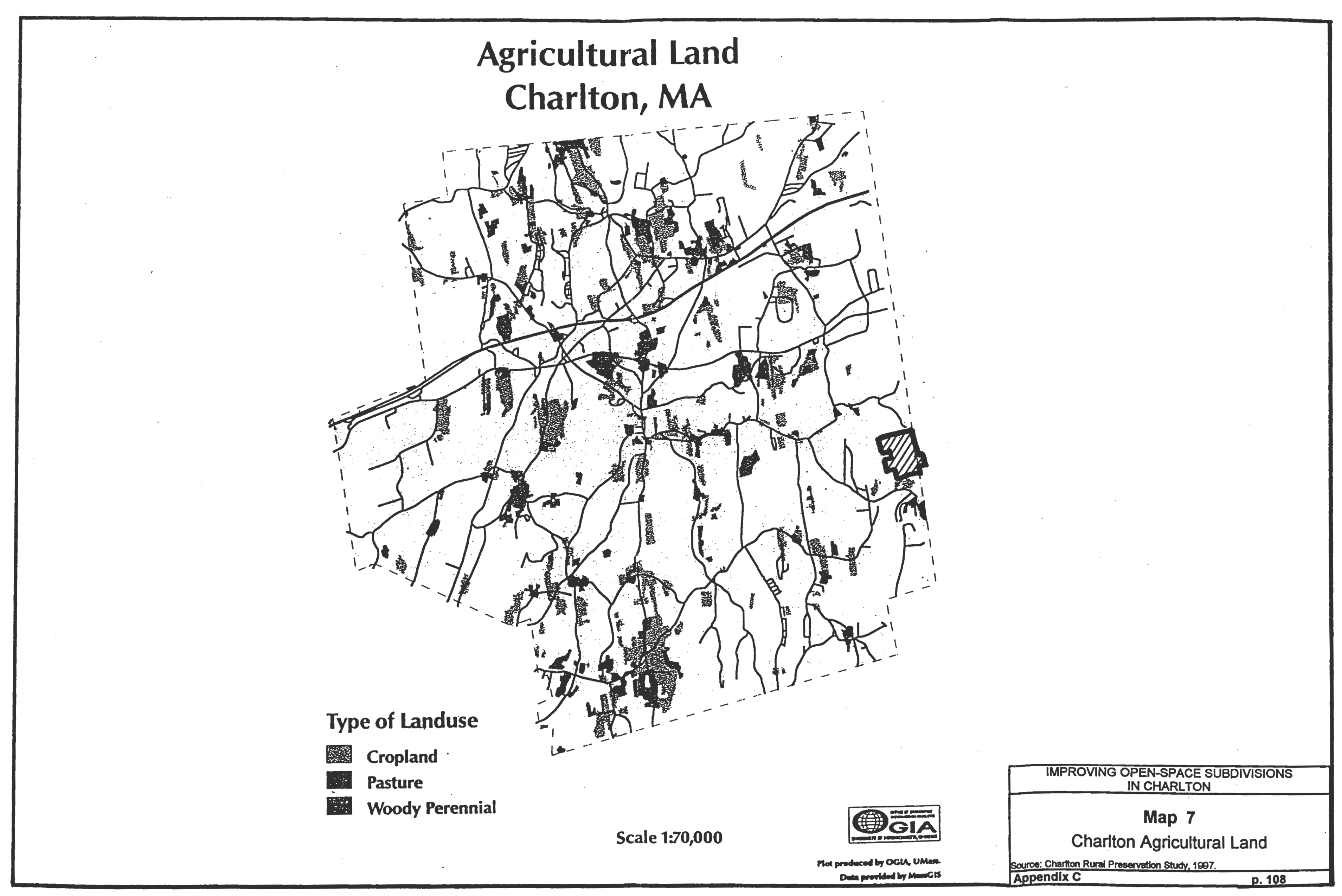




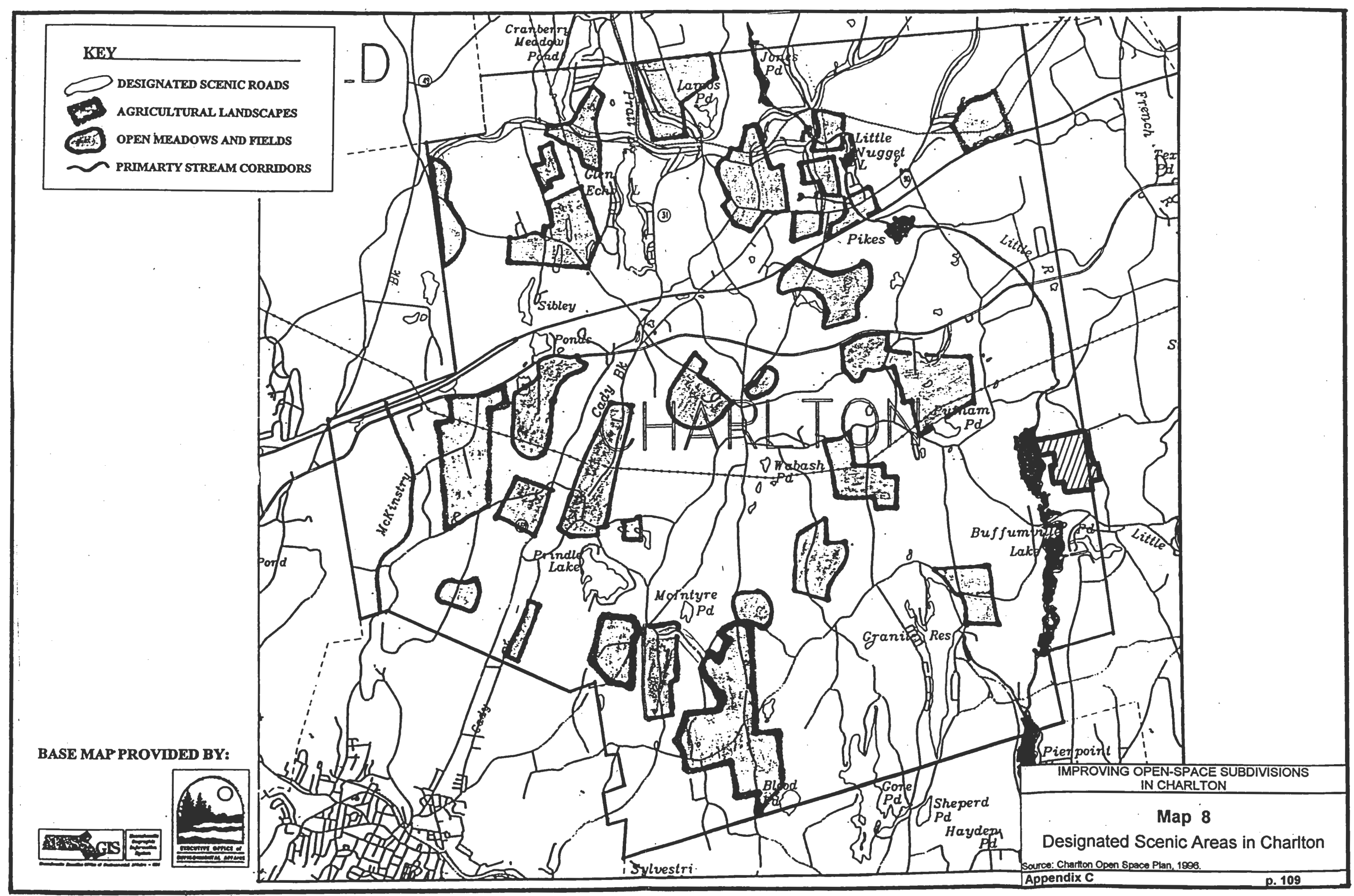




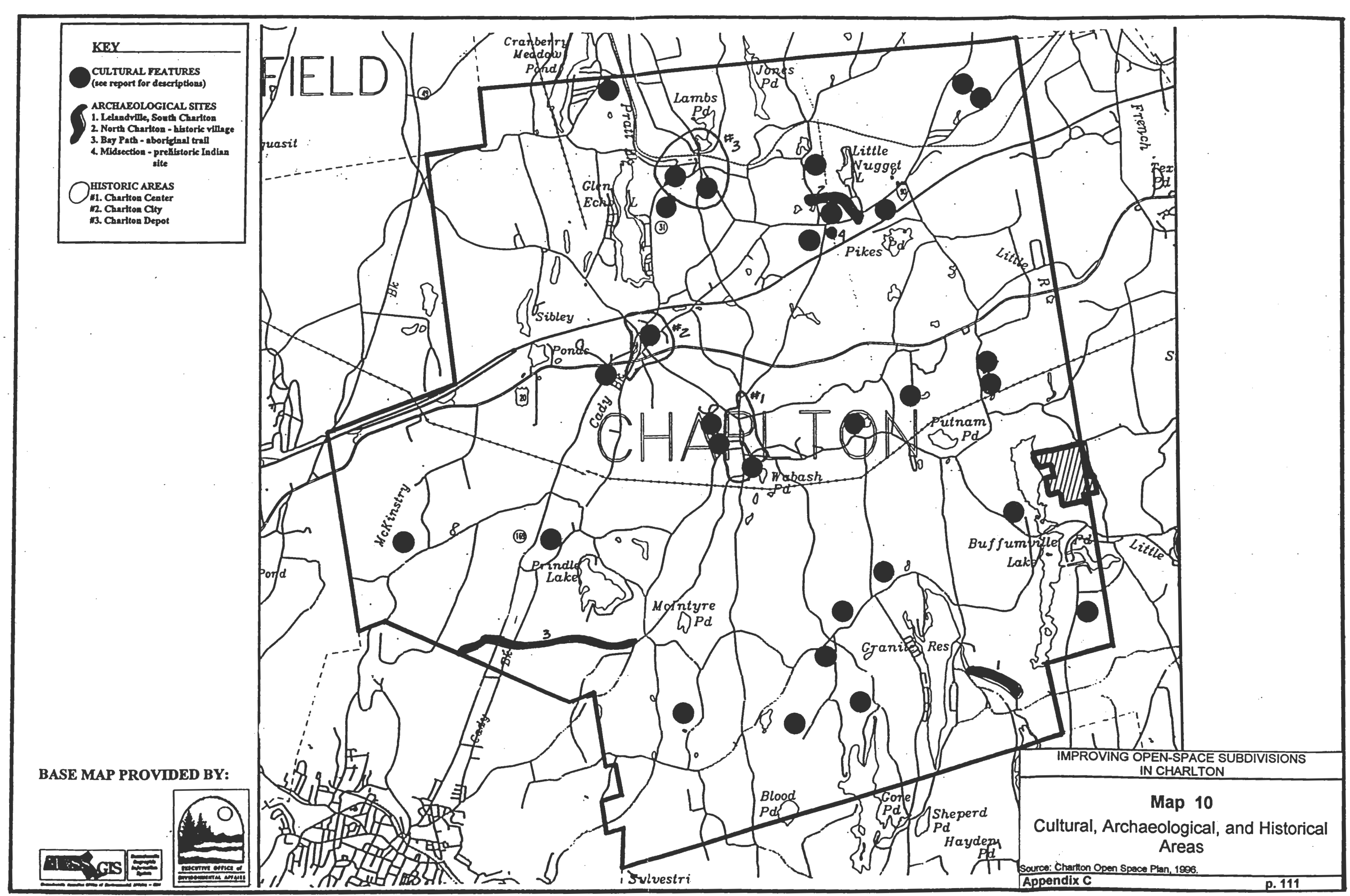




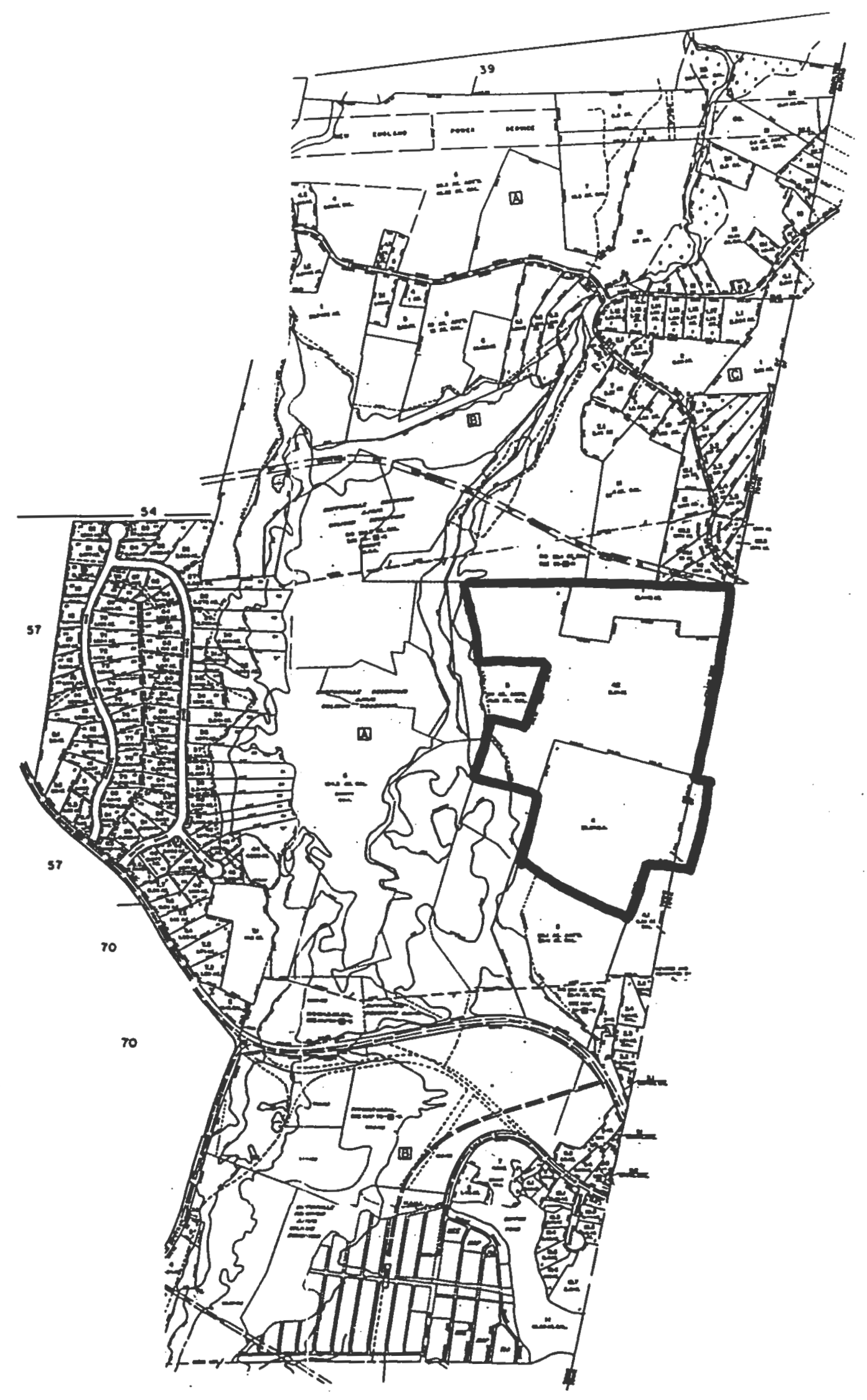




\section{Appendix D}

\section{Large-Scale Absorption System Design}

\section{A. Calculations:}

\section{Given:}

1) \# dwellings in cluster $=6$

2) \# bedrooms per dwelling $=3$

3) total \# bedrooms $=18$

4) trash disposal units are used

5) $\mathrm{gal} / \mathrm{day} / \mathrm{bedrm}=110 \mathrm{gpd}$

6) total gpd $=18 \times 110=1,980$

7) absorption standard $=.33 \mathrm{gal} / \mathrm{hr}$ (due to very poor soils)

8) square feet of absorption area per linear $\mathrm{ft}$. of 24 " wide trench $=6 \mathrm{sq} . \mathrm{ft}$

9) maximum length available for each trench $=100 \mathrm{ft}$.

10) total absorption area per trench $=600$ sq.ft.

11) maximum width available for absorption field $=180 \mathrm{ft}$.

12) total number of possible trenches (spaced $6 \mathrm{ft}$.apart, edge to edge) $=22$

\section{Required square feet of trench (per dwelling unit):}

sq.ft. of trench per unit $=$ total gpd per unit $\div$ absorption standard

$$
\begin{array}{lll}
= & 330 \quad \div & .33 \\
= & 1,000 \text { sq.ft trench }
\end{array}
$$

factor in trash disposal $=1,000 \times 1.5=1,500$ sq. $\mathrm{ft} . / \mathrm{dwelling}$ unit

\section{Number of trenches required (per dwelling unit):}

$$
\begin{aligned}
\text { number of trenches } & =1,500 \text { sq. } \mathrm{ft} \div 600 \text { sq. } \mathrm{ft} . / \text { trench } \\
& =2.5 \text { trenches }=3 \text { trenches (rounded up) }
\end{aligned}
$$

\section{Number of trenches required for all dwelling units:}

$$
\begin{aligned}
\text { number of trenches } & =6 \text { dwellings } \times 3 \text { trenches } \\
& =18 \text { trenches }
\end{aligned}
$$


V. Total width needed for all absorption trenches:

$$
\begin{aligned}
\text { total width } & =(18 \times 2 \mathrm{ft})+(18 \times 6 \mathrm{ft})+(6 \mathrm{ft}) \\
& =36 \mathrm{ft} .+108 \mathrm{ft} .+6 \mathrm{ft} . \\
& =150 \mathrm{ft} .
\end{aligned}
$$

VI. Total area needed for all absorption trenches:

$$
\begin{aligned}
\text { total area } & =150 \mathrm{ft} . \times 100 \mathrm{ft} . \\
& =15,000 \mathrm{sq} . \mathrm{ft} .
\end{aligned}
$$

B. Absorption Field Design:

\section{Overall Concept:}
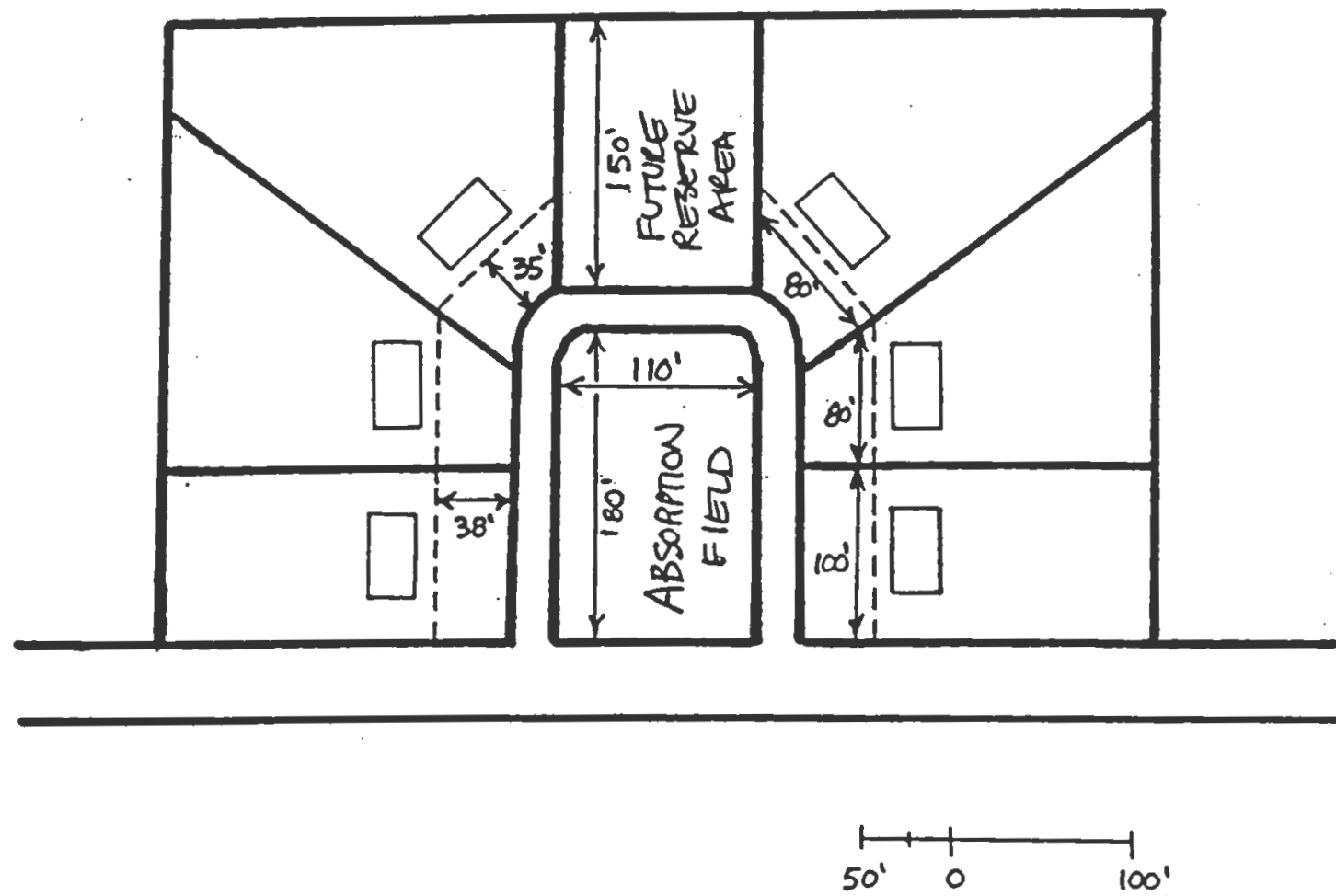


\section{IL. Disposal Area Detaili:}

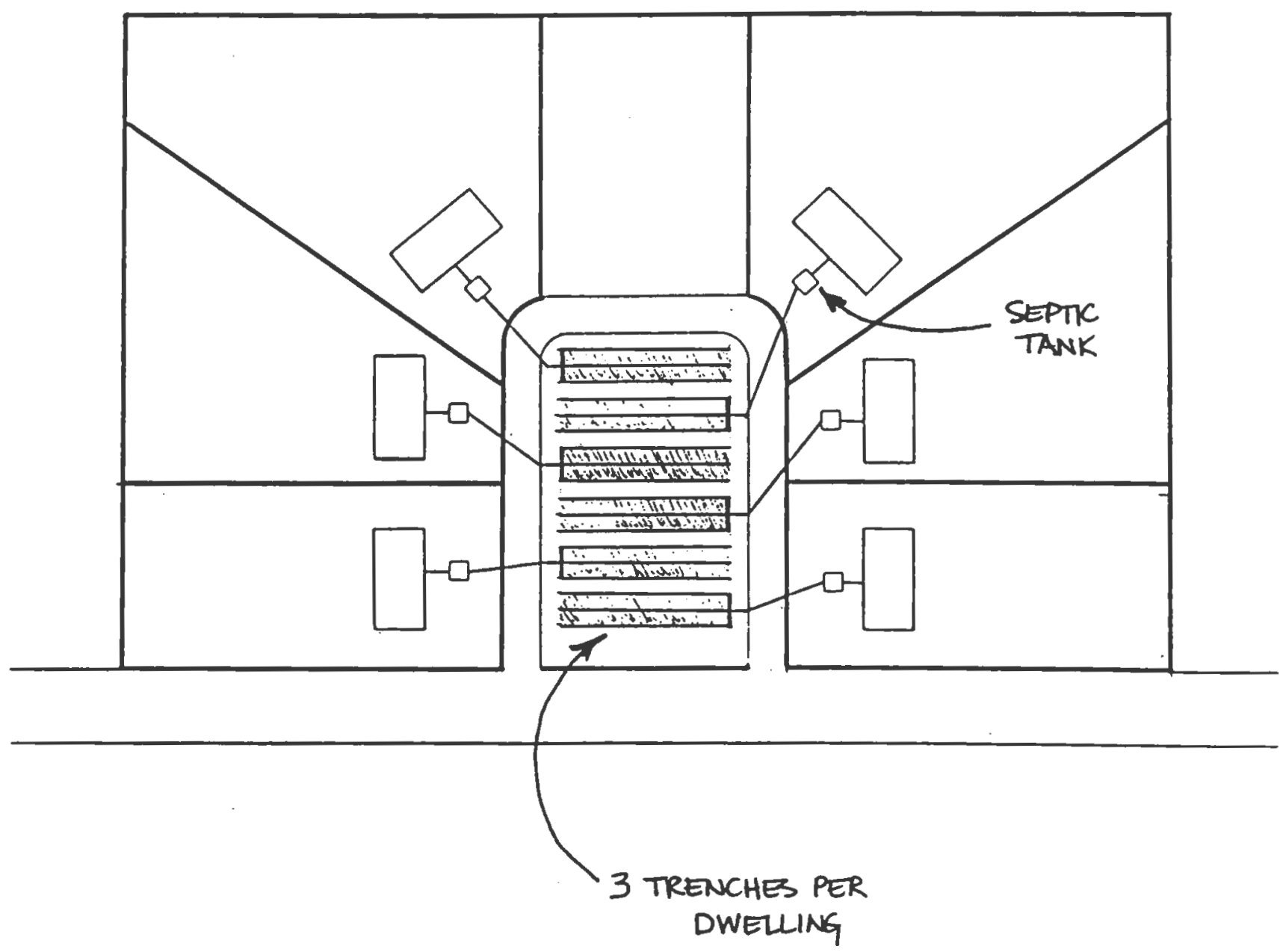




\section{Appendix E}

\section{Schofield Heights Design Feedback Forms}

\begin{tabular}{cl} 
Sequence \# & \multicolumn{1}{l}{ Respondent } \\
0011 & Developer 1 \\
0022 & Developer 2 \\
0033 & Real Estate Agent \\
0044 & Land Surveyor \\
0055 & Professional Engineer \\
0066 & Town Conservation Agent \\
0077 & Town Health Agent \\
0088 & Town Engineer \\
0099 & Developer 3
\end{tabular}


Feedback Form \# 0011

0011

\section{Master's Degree Thesis Project of Bruce Keller Open-Space/Flexible Development of Schofield Heights Feedback Sheet}

Background and Intructions:

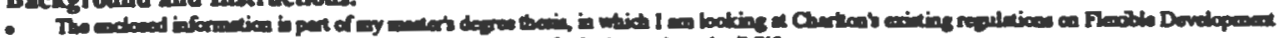

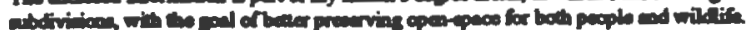

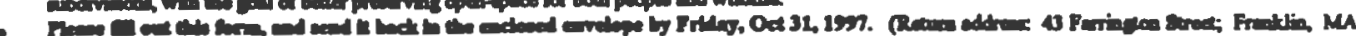

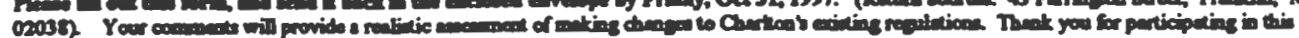
projeds

1) Given what yoa've read/seen in the enclowed documenth, what are yoar overall oplajond of Dedign Scheme "A" ? (check noo)

1 It adequately moess all of the goals identified for the project (identified on page 3 of chapter 5).

1) It only meets a couple of the goals identified for the project.

0 It barchy meets the goels identified for the project.

It would likely be a very martectable project.

if if my or may not be a marketable project

D It would be a difficult project to market.

Complications with design to be arwe of:

Beneficial aspects of design to be awnere of:

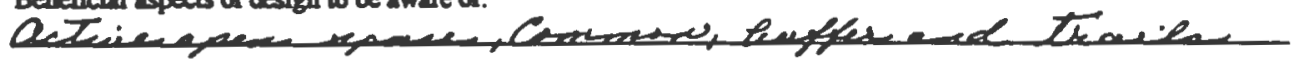

2) Gives what you've read/seen in the eaclosed documenth, what are your overall opinions of Decign Scheme "B" ? (check noo)

D It adequately meets all of the poals identified for the project (identified on page 3 of chapter 5).

4 It only meets a couple of the goals identified for the project.

I It barcty moets the goals identified for the project.

O It would likety be a very marketable project.

It my or may not be a markecable project.

Of It would be a dificialt project to martect.

Complications with design to be awere of:

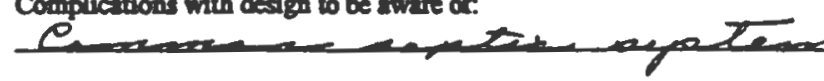

Beneficial aspects of design to be awre of:

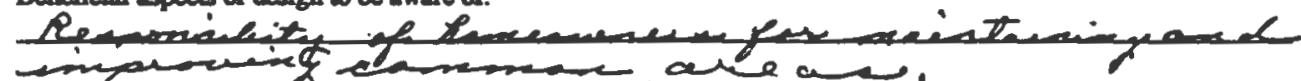

3) In yoar oplnion, is the extra fork brvived with the enalyats and desion phnses worth the effort?

$\mathbf{Y}$

6 $\mathrm{N}$ If "No", would you reconsider if Pinnning a Conservation stafo actecence from the Town of Chariton were made available for these areas? DY DN

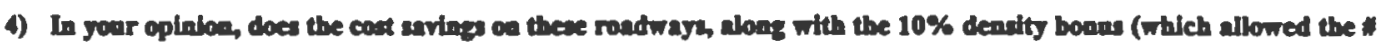
of lots in this project 80 from 50 to 55 lot) fairly compensate the developer for the added initial dedign work and coet of wallding trills? $\mathrm{Y}$ ON

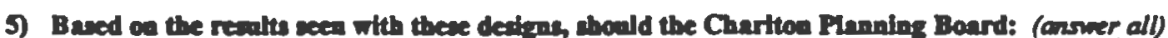

2. Consider reducing lot sizes down to $30,000 \mathrm{~m} / \mathrm{h}$ in open-epece subdivisions? B $\mathrm{X}$ DN

b. Consider allowing 20,000 an it. lots for bomes on common septic systems? . $\mathrm{Y} Y \mathrm{~N}$

c. Consider allowing frominge on 20-foot wide common lanes/drives in opeo-rpece subdivisions, as long as these lanes are owned and maintained by come type of "homeowner's associntion"? $0 Y \sim N$

d. Allow the dencity bonus for lots to 80 up $1020 \%$, and allow the percentage of open-spece to 80 down $1040 \%$ as long as additiond amenities are provided by the developer, wch as one or more of the following: grzebos, mailroom sheliers, playerounds, stone walls, picket fences, etc.? 


\section{Master's Degree Thests Project of Bruce Keller Open-Space/Elexible Development of Schofield Heights Feedback Sheet}

Backgroand and Instructions:

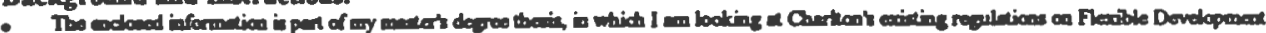

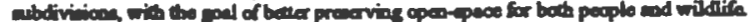

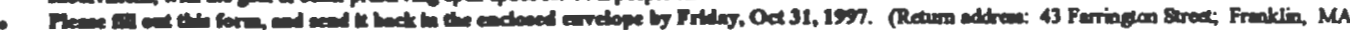

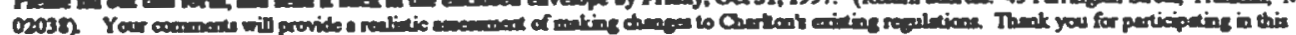
projocl

1) Gtven what you've read/seen in the enclosed documents, what are your overall opinions of Desiga Scheme "A" ? (check nuo)

X It adoquately meets all of the goals identified for the project (identified on page 3 of chapter 5).

II only meets a couple of the goals identified for the project.

I It barely moets the goals identified for the project.

\& It would likely be a very marketable project.

II may or may not be a marbetable project.

0. It would be a difficult project to market.

Complications with design to be aware of:

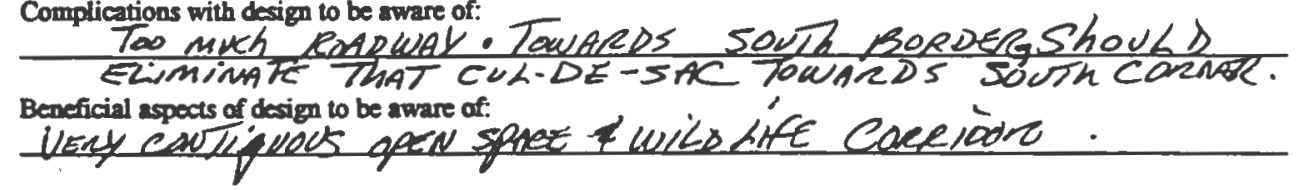

2) Given what you've read/scen in the enclosed documenth, what are your overall opinions of Deaign Scheme "B" ? (check nwo)

2. It adoquately meets all of the goals identified for the project (identified on page 3 of chapter 5).

D It oaly meets a couple of the goals identified for the project.

I It barely moets the goals identified for the project.

Y'. It would likety be a very marketable project.

I It may or may not be a marketable project.

0 It would be a difficult project to market.

Complications with design to be awne of:

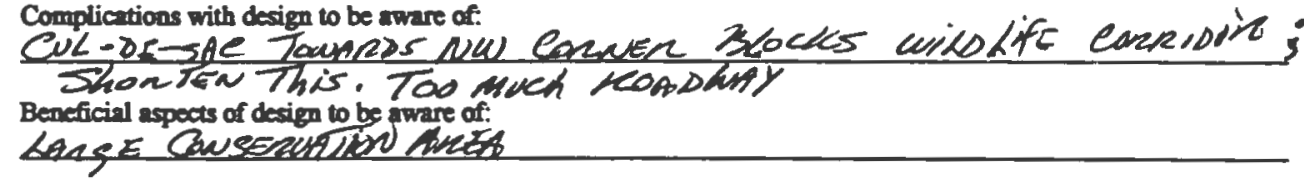

3) In ygar opinion, is the extra work involved with the mabysis and dexign phases worth the effort? BY

D N If "No", would you reconsider if Planning \& Conservation afaff escistance from the Town of Chariton were made available for these areas ? D $\mathrm{Y}$, $\mathrm{N}$

4) In yoar opinion, does the cout anvings on these randwayh along with the $10 \%$ density bonus (which allowed the : of lots in this project go from 50 to 55 lots) fairly compensate the developer for the added lnitial dealga work and cost of wallding trills? XY DN

5) Based an the results seen wth these designs, should the Chartton Planning Based: (onswer all)

2. Consider rectucing lox sizes down to 30,000 q $\mathrm{fl}$ in open-epece rubdivisions? ................. IY DN

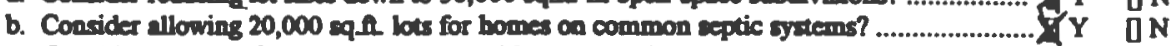

c. Consider allowing frontage on 20-foot wide common lanes/drives in open-apace abdivisions, as long as these lanes are owned and maintained by some type of "homeowner's association"?................. I Y ] N

d. Allow the density boms for lots to 80 up to $20 \%$, and allow the percentuge of open-epece to go down to $40 \%$ as long as adtitional amenities are provided by the developer, such as one or more of the following: gazebos, mailioom shelters, playerounds, stope walls, pichet fences, etc.?

$$
\text { - THANKS AGAN FOR YOUR TMMEI- }
$$

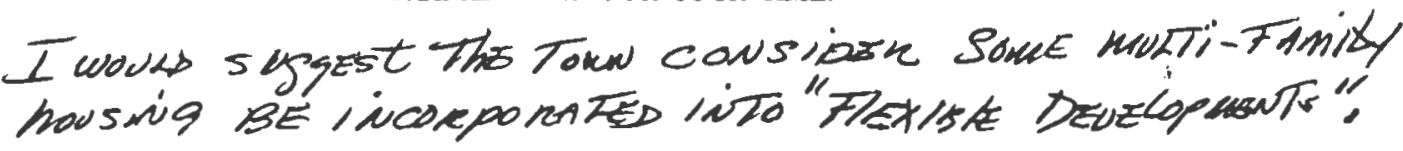


Feedback Form\# 0033

\author{
33 \\ Marter's Degree Thesis Project of Bruce Keller \\ Open-Space/Elexible Development of Schofield Heights \\ Feedback Sheet

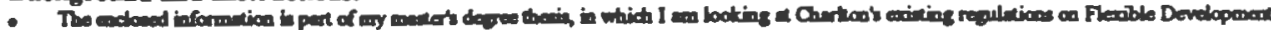

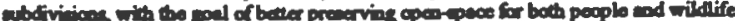

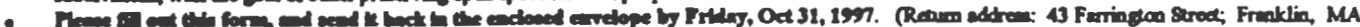

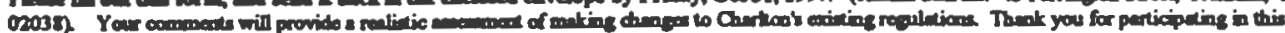

Background and Instructions: projocts

1) Given what you've read/reen in the enclosed documents, what are your overall opinions of Design Scheme " $A^{n}$ ? (check no)

D It adoquately meets all of the goals identified for the project (identified on page 3 of chapter 5).

It onty meets a couple of the goals identified for the project.

OI It barely meets the goals identified for the project.

D It would likety be a very marketable project.

(1) It may or may not be a marketable project.

It would be a difficult project to market.

Complications with design to be wware of:

HJuse LOTS ON ONE SIDE GF POAD.

Beneficial aspocts of design to be aware of:

MUCH OPEN \& PRirATE SPACE.

2) Given what you've read/reen in the exclosed documenth, what are your overall opinions of Deaign Scheme "B" ? (chect nom)

It adequately meets all of the goals identified for the project (identified on page 3 of chapter 5).

Di It only meets a couple of the goals identified for the project.

D It barch meets the goals identified for the project.

[1 It would likely be a very marketable project.

D It may or may not be a marketable project

It would be a difficult projoct to martee.

Complications with design to be aware of:

HASELATS ON ONESIDE DF ROASO.

Bencficial aspects of desigen to be awre of:

MORE AN OPEN FE PRUATE IPACE

3) In your opinlon, ts the extra work involved wth the cnabysis and dexign phases worth the cfion?

$\mathrm{Y}$

D N If "No", would you reconsider if Planning \& Conservation edof asvistance from the Town of Charlion were made available for these areas? $0 \mathrm{Y}$ DN

4) In your opinion, does the cout anvinge on these randwayk, along with the $10 \%$ density bonu (which allowed the * of lots in this project go from 50 to 55 lots) falrly compenuate the developer for the added inftial dentgn work and cont of walling tralla? DY IN is ciose

5) Based on the realts sees wth these decigns, would the Chartiton Planning Board: (answer all)

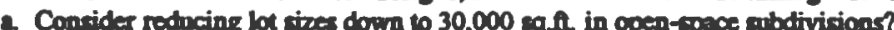

$\mathrm{Y} D \mathrm{~N}$

b. Consider allowing 20,000 eq $\mathrm{fl}$ lot for bomes on common reptic sytems? D́ Y N

c. Consider allowing frontage on 20-foot wide common lenes/drives in open-epace subdivisions, as long as these lanes are owned and mointained by some type of "homeowner's ascocintion"?. Y Y N

d. Allow the density bonns for lots to zo up to 20\%, and allow the percentage of open-apace to go down to $40 \%$ as long as additional amenities are provided by the developer, anch as one or more of the following: gazebos, mailroom shelters, plagrounds, wone wills, pictet fences, etc.? C $\mathrm{Y}$ N

$$
\text { - THANKS AGAIN FOR YOUR TIMEI- }
$$




\section{Eeedback Form \# 0044}

\section{4}

\section{Master's Degree Thesss Project of Bruce Keller Open-Space/Flexible Development of Schofield Heights Feedback Sheet}

Backeground and Inatructions:

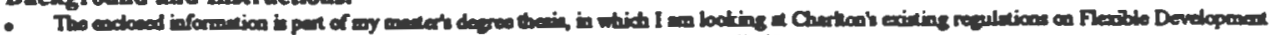

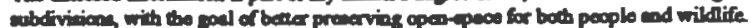

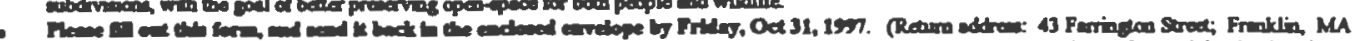

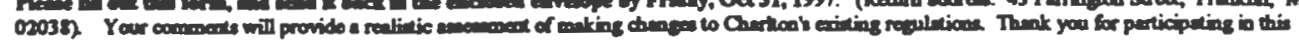
projedil

1) Given what you've read/seen in the eaclosed documents, what are your overall opinions of Deaign Scheme "A" ? (check no)

D It adequately meets all of the goals identified for the project (identified on page 3 of chapter 5). X. It only meets a couple of the goals identified for the project.

II It barely meets the goals identified for the project.

D It would likely be a very maricetable project.

D It may or may not be a marketable project.

¿ It would be a difficult project to marlet.

Complications with design to be aware of:

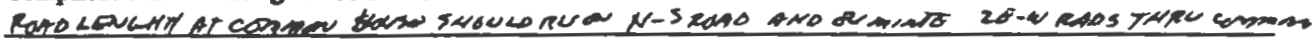

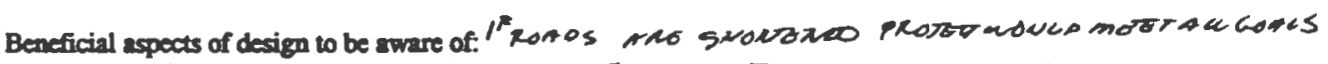

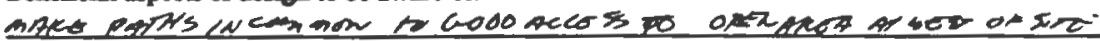

2) Given what you've read/seen in the cuclosed documente, what are your overall opinions of Derign Scheme "B" ? (chect no)

11 It adequately meess all of the goals identified for the project (identified on page 3 of chapter 5 ).

(7) It only meets a couple of the goals identified for the project.

(I) It barely mots the goals identified for the project.

I It would likely be a very maricetable project.

[I It msy or mgy not be a marketable project.

If It would be a dificult project to market.

Complications with design to be sware of:

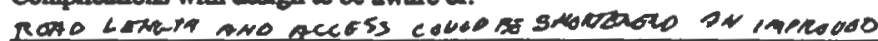

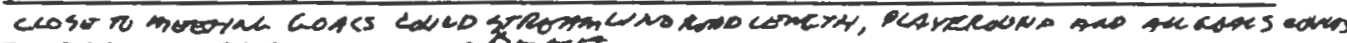

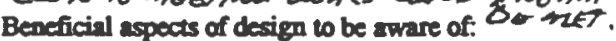

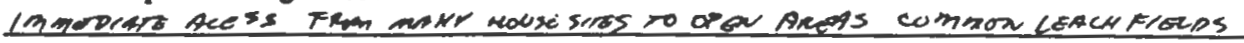

3) In Joer optnion, is the extra nork involved with the arabris and design phases wrorth the effort?

] $\mathbf{Y}$

QKN If "No", would you reconsider if Planning \& Conservation adof astatance from the Town of Chariton

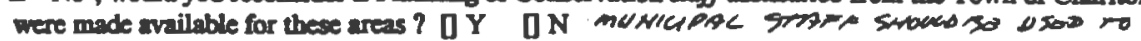

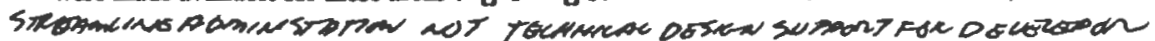

4) In your opinlog, does the cost avings on these roadways, along with the $10 \%$ dencity bonus (whlch allowed the of late in this project go from 50 to 55 bote) (aidy compenste the developer for the added initial design work and coat of ralling trallis gY DN

5) Based on the realts coen with thewe dedigns, should the Chartion Panning Board: (answer all)

a. Consider roducing lot tzes down to 30,000 eq. in open-epece sobdivisions? ................ XYY DN

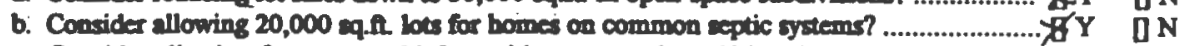

c. Consider allowing frouthes on 20 -foot vide common lance/drives in open-epece subdivisions, as long ss these hnes are owned and maintined by some type of "homeowner's association"?................ XY U N

d. Allow the density bous for los to 80 up $1020 \%$, and allow the percentage of open-space to go down to $40 \%$ is long as additional amenities are provided by the developer, anch as one or more of the following: gazebos, milroom sheliex, playgrounds, sone walls, picket fences, etc.? 


\section{Feedback Form \# 0055}

\section{Master's Degree Thesis Project of Bruce Keller \\ Open-Space/Flexible Development of Schofield Heights}

0055

Background and Instructions:

Feedback Sheet

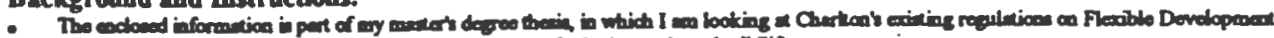

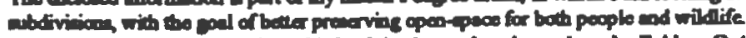

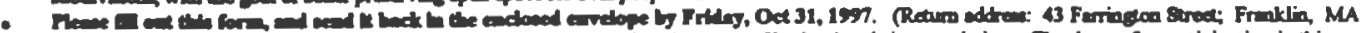

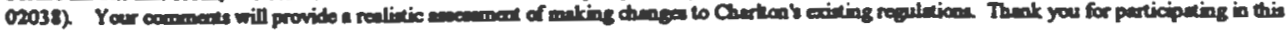
projods

1) Given what you've read/ecen in the enclosed documents, what are your overall opinions of Deaign Scheme "A" : (check no)

X. It adequately meets all of the goals identified for the project (identified on page 3 of chapter 5).

1) It only meets a couple of the goals identified for the projoct.

D It barely meets the goals identified for the project.

[1 It would likely be a very marketable projoct.

2. It may or may not be a marketable project.

0 It would be a difficult project to market.

Complications with design to be awrare of:

INDIVIDUAL LOT OWWERSHIP VS. COMMON OPEN SPACE AREAS

Beneficial espocts of design to be arware of: COREAT OPEN SPACE OAPNCTUNITIES

2) Given what you've read/seen in the enclosed documente, what are your overall opinlons of Deaign Scheme "B" ? (chect nor)

W It adequately meets all of the goals identified for the project (identified on page 3 of chapter 5).

I] It only meets a couple of the goals identified for the projoct.

D 14 bercty meets the goals identified for the projoct.

[1 It woold likely be a very marketable project.

II If may or max not be a maribetable project.

Zil would be a difficull projoct to market.

Complications with design to be awrare of:

LOCATIUN OF COMMON LEACA AREMS DICMATES SY SOIL CONAITNNS

Beneficisl aspects of design to be aware of:

EXCEUENT OPEN SPACE

3) In your opinion, is the extra work involved with the analysis and design phases worth the effort?

D Y

XN If "No", would you reconsider if Planning \& Conservation asf essistance from the Town of Chartion were made available for these areas? $\mathrm{XY}$ DN

4) In your opinion, does the cont aving on these rosdwajn, along with the $10 \%$ denaity bonus (whlch sllowed the " of lots in this project go from 50 to 55 lots) fairly compensate the developer for the added initial deaign work and cost of wallese tralle? XY [ON

5) Based ca the resolts seen with these designs, shoold the Chartiton Pianning Board: (answer all)

2. Consider reducing lot sizes down to $30,000 \mathrm{eq}$. fl in open-mece subdivisions?

OS $0 \mathrm{~N}$

b. Consider allowing 20,000 aqf bets for homes on common extic systems? ....................... D $Y$ XN

c. Consider allowing trontuge on 20-foot wide common lanew/drives in open-tpece subdivisions, as long as these lanes are owned and maintained by some type of "homeowner's association"?................ PXY DN

d. Allow the denrity boums for lots $10 \mathrm{go}$ up to 20\%, and allow the percentage of open-space to 80 down $1040 \%$, as long as additional amenities are provided by the developer, wich as one or more of the following: gazcbos, mailroam chelteces, pigrerounds, stone walls, picted fences, etc.? $\alpha \mathbf{N}$ i

\footnotetext{
- THANKS AGAN FOR YOUR TLMEI -
} 


\author{
0066 \\ Master's Degree Thesis Project of Bruce Keller

\section{Open-Space/Flexible Development of Schofield Heights} \\ Feedback Sheet

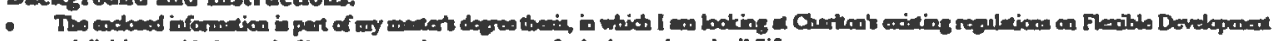

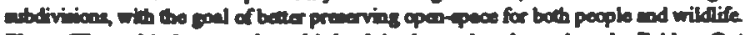

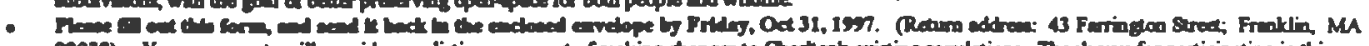

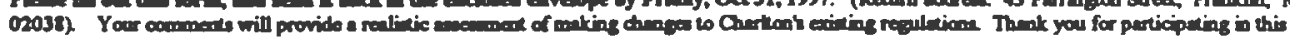

Background and Instructions: projeat!

1) Given what you've read/seen in the enclosed documents, what are yoor overall opinions of Design Scheme "A" ? (check no)

It adoquately moets all of the goals identified for the project (identified on page 3 of chapter 5).

0 It only meets a couple of the goals identified for the project.

0 It barely moets the goals identified for the project.

0 It would likely be a very marketable project.

I It may or may not be a marketable project.

0 It would be a difficult project to maricet.

Complications with design to be aware of:

maintenance ifopen space - agreement m hur to be uhlind - have a deed to consenvation wim restrichions may be a ged idia.

Beneficial aspects of design to be aware of:

eptimal use of space.

2) Given what you've read/seen in the enclosed documents, what are your overall opinlons of Deaign Scheme "B" ? (check noo)

It adequately meets all of the goals identified for the project (identified on page 3 of chapter 5).

1] It conly meets a couple of the goals identified for the project.

1] It berchy meets the goals identified for the project.

[ It would likely be a very maricetable projoct.

0 It may or may not be a marketable project.

0 It would be a difficult project to market.

Complications with design to be atware of: is the cest for the land there pothes hwised paid th Thruan of socialeienBeptimal Use of space

3) In your opinion, is the extra work involved with the anabyis and design phasea worth the effort?
$\square \mathbf{Y}$
I N If "No", would you roconsider if Planning \& Conservation eaff acsictance from the Town of Charlton were made available for these areas? D Y D N

4) In your opinion, does the cout avinge ca thewe roadways, along with the $10 \%$ density bonns (which allowed the : of lots in this project go from 50 to 55 lota) fairly compenute the developer for the added initial design work and cont of walking trails? $\square \mathrm{Y}$ ] $\mathrm{N}$

5) Based on the realts seen with these designs, should the Chartion Planning Basind: (onswer all)

2. Consider reducing lor sizes down to 30,000 eq.ft in open-epece subdivisions?

b. Consider allowing 20,000 eq. Il. lots for bomes co common septic sytems? .. $\mathrm{Y} \square \mathrm{N}$

c. Consider allowing fronter on 20 -foct vide common lanes/drives in open-................. DY UN nut guve lenes are owned and maintained by some type of "homeowner's association"? III $\mathrm{Y}$

d. Allow the density boums for lots to go up to 20\%, and allow the percentage of open-space to go down to $40 \%$ as long as additional amenities are provided by the developer, such as one or more of the following: gazcbos, mailroom shelvers, playsrounds, wone walls, pictret fences, etc.? I Y $\mathrm{N}$

\title{
- THANKS AGAIN FOR YOUR TLMEI-
}


Eeedback Form \# 0077

\section{7 \\ Master's Degree Thesis Project of Bruce Keller Open-Space/Flexible Development of Schofield Heights Feedback Sheet}

Background and Instructions:

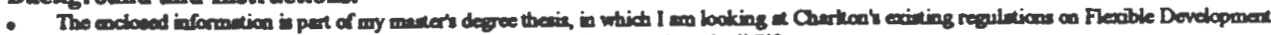
abdivitions with the roul of beter prearving cpon-pece for both people and willifife

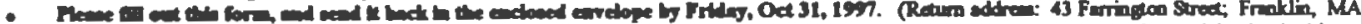

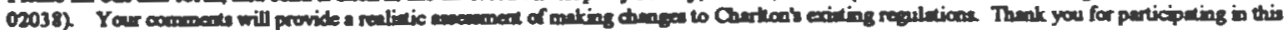
project

1) Given what you've read/seen in the enclosed documents, what are your overall opinions of Deaign Scheme " $A$ " ? (check two)

- It adoquately meets all of the goals identified for the project (identified on page 3 of chapter S).

1] It only moets a couple of the goals identified for the project.

D. It barely meets the goals identified for the project.

0 It would likely be a very marketable projoct.

It It may or may not be a marketable project.

0 It would be a difficult project to market.

Complications with design to be awrare of:

Beneficial aspects of design to be aware of:

2) Given what you've read/seen in the eaclosed documents, what are your overall opiaions of Design Scheme "B" ? (check noo)

I I adequately meets ail of the goals identified for the project (identified on page 3 of chapter 5).

'D It only moess a couple of the goals identified for the projoct.

D. It barety meets the goals identified for the project.

X. It would likety be a very marketable projoct.

i] It may or may not be a marketable project.

[] It would be a difficult project to market.

Complications with design to be aware of:

Beneficial aspects of design to be aware of:

3) In your opinion, is the ertra work involved wtth the andysis and dexign phases worth the effort?

Y

If "No", would you reconsider if Planning \& Conservation staf assistance from the Town of Charlton were made available for these areas? D $\mathrm{Y} \quad$ D N

4) In your opinion, does the cont avings on theac roatwayn, along with the $10 \%$ density bonus (which allowed the " of lots in this project go from $50 \mathrm{tg} 55$ lots) fally compensate the developer for the added initial decign work and cast of walking tralls? $\mathrm{LY}_{\mathrm{Y}} \mathrm{UN}$

5) Based on the reaults cees wth these designs, shoald the Chartion Planning Basud: (answer all)

2. Consider reducing lot sizes down to 30,000 \&q.t. in open-epece mubdivisions?

b. Consider allowing 20,000 sq.t. lots for homes on common septic systems? ...

D Y $T^{\prime}$

......... D $Y$ Y

(roning frontage on 20-foot wide common lanes/drives in open-space subdivisions, as long as these lanes are owned and maintained by some type of "bomeowner's association"? D $\mathrm{Y} X \mathrm{X}$

d. Allow the density bonus for lots to go up to $20 \%$, and allow the percentage of open-space to go down to $40 \%$, as long as additional amenities are provided by the developer, axch as one or more of the following; gazebos, mailroom shelters, playgrounds, stone walls, picket fences, etc.?

$$
\text { - THANKS AGAIN FOR YOUR TLMEI- }
$$


Background and Instrections:

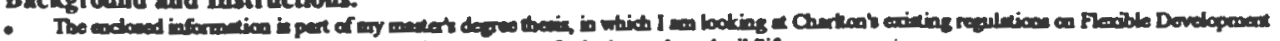

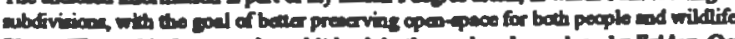

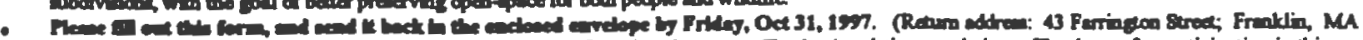

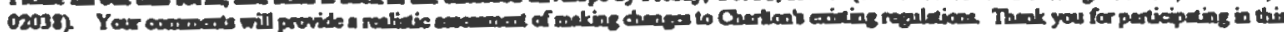
projoal

1) Given what you've read/seen in the enclosed documenth, what are your overall opinioas of Design Scheme "A" ? (check no)

It adequately meets all of the goals identified for the projoct (identified on page 3 of chapter 5).

(1) only meets a couple of the goals identified for the project.

1. It barely moets the goals identified for the project.

D It would likely be a very marketable project.

It may or may not be a marbetable project.

D. It would be a difficult project to marlet.

Complications with design to be awere of:

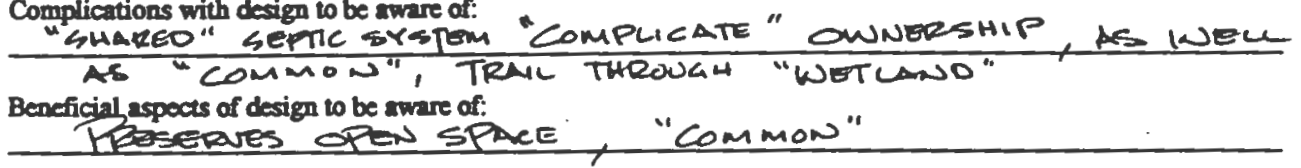

2) Given what you've read/scen in the enclosed documents, what are your overall opinlons of Dedign Seheme "B" ? (check no)

It adequatchy moets all of the goals identified for the projoct (identified on page 3 of chapter 5).

D It only meets a couple of the goals identifiod for the project.

D It barcly meets the goals identified for the project.

D It would likely be a very marketable project.

It may or may not be a marketable project.

0 It would be a difficult project to mariket.

Complications with design to be aware of: (ses areves)

Beneficial aspocts of design tobe aware of: (SEE APOVE)

3) In your opinion, is the ertra work lavalved with the cuabysis and dexign phases worth the effort?
$\mathbf{Y}$
D N If "No", would you reconsider if Planning \& Conservation afaf acsirtance from the Town of Chariton were made available for these areas? प $\mathrm{Y}$, $] \mathrm{N}$

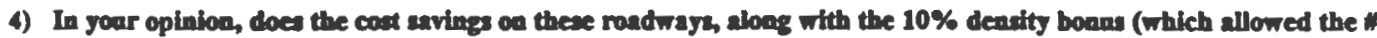
of lots in this project go from 50 to 55 lots) fairly compensate the developer for the added initial detiga work and coet of wallding trails?

$$
\square \mathbf{Y} \quad \mathbf{D}
$$

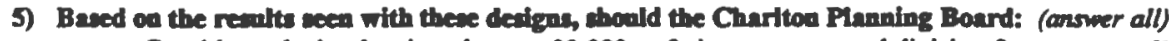

2. Consider reducing lat irzes down to $30,000 \mathrm{mql}$ in cpen-epece subdivisions? Y $\mathbf{Y}$

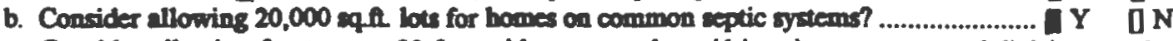

c. Consider allowing frontage on 20 -foot wide common lanes/drives in open-rpence subdivisions, os long as these lanes are owned and maintained by rome type of "homeowner's association"'? $\square \mathrm{Y}$ DN

d. Nllow the density boms for lots to go up to 20\%, and allow the percentage of open-ppace to 80 down to $40 \%$ as long as additiomal amenities are provided by the developer, wuch as one or more of the following: gazebos, mailroom shelien, playgrounds, stone walls, picket fences, etc. 7 I $\mathbf{Y} \mathbf{N}$

$$
\text { - THANKS AGAN FOR YOUR TIMEI - }
$$




\section{Master's Degree Thesis Project of Bruce Keller \\ Open-Space/Flexible Development of Schofield Heights \\ Feedback Sheet}

Background and Instructions:

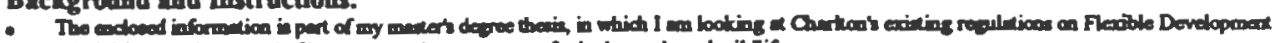

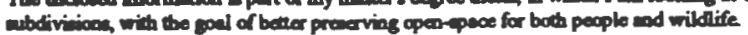

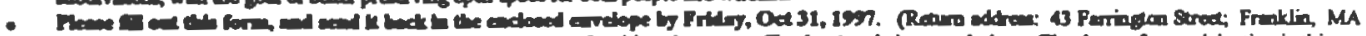

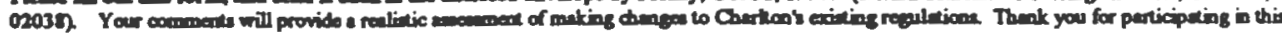
projed

1) Glven what you've read/scen in the enclowed documents, what are your overall opinions of Design Scheme "A" ? (ch stivo)

At adequately meets all of the goals identified for the project (identified on page 3 of chapter 5).

0 It only moets a couple of the goals identified for the project.

II It barely meets the goals identified for the project.

If It would likely be a very marketable project.

II It may or may not be a marketable project.

D It would be a difficull project to market.

Complications with design to be aware of:

Beneficial aspects of desigu to be aware of:

2) Given what you've read/seen in the enclosed documents, what are your overall opinions of Deaign Scheme "B" ? (check two)

D It edequately meets all of the goals identified for the project (identified on page 3 of chapter 5).

1] It only meets a couple of the goals identified for the projoct.

1] It barely moets the goals identified for the project.

I It would likely be a very marketable project.

[1 It may or may not be a marketable projoct.

II It would be a difficult project to market.

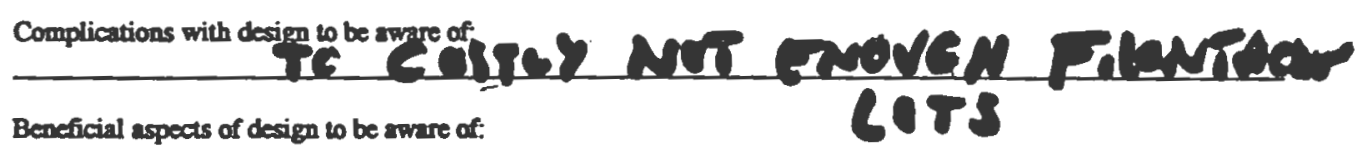

3) In yourn-ion, is the extra work involved with the analysis and dexign phuses worth the effort? I If "No", would you reconsider if Planning \& Conservation effof ascirance from the Town of Charlion were made available for these areas ? [ Y $[\mathrm{N}$

4) In your opinion, does the cont avings on the- Toudways, along with the $10 \%$ density boun (which allowed the : of lots in this project go frem 50 to 5 " uts) fairty compensate the developer for the added laltial detign work and cost of walling tralls? [ $\mathrm{N}$

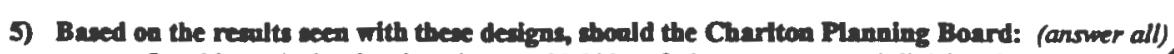

2. Consider reducing lot sizes down 2030,000 eq. $\Omega$ in open-epace subdivisions?

b. Consider allowing 20,000 eq.ft lots for bomes on common expic systems? ...

c. Consider allowing arow Conser allowing frontage on 20-foot wide common laned/drives in open-space subdivisio, as long as these hnes are owned and maimtained by some type of "homeowner's association"?............... if [N

d. Allow the density bonus for lots to 80 up $2020 \%$, and allow the percentage of open-spece to 80 ب. $\mathrm{h}$ to $40 \%$ as long as additional amenities are provided by the developer, such as one or more of the foll ing: gazebos, milroom shellers, playgrounds, wone wills, picket fences, etc.?

\section{- THANKS AGAIN FOR YOUR TIMEI-}




\section{Bibliography}

Abell, George O., David Morrison, et al. 1987. Exploration of the Universe. Philadelphia: Saunders College Publishing.

Abramovitz, J.N. 1997. State of the World 1997: Introduction to Chapter 6: Valuing Nature's Services. Internet Website: www. wri.org; File Name:natsvcs.htm. World Resources Institute.

Amir. S. 1995. Methodological and Ideological Options:The Environmental Cost of Sustainable Welfare. Ecological Economics 13: 27-41.

Arendt. Randall, Elizabeth A Brabec, et al. 1994. Rural By Design: Maintaining Small Town Character. Chicago: American Planning Association.

Arendt. Randall G. 1996. Conservation Design for Subdivisions. Washington, DC: Island Press.

Baetz, B.W. 1994. Creation of Landowner Compacts for Sustainable Community Development. Journal of Urban Planning and Development 120: 174-82.

Barbier, E.B. and A. Markandya. 1990. The Conditions for Achieving Environmentally Sustainable Development. European Economic Review 34: 659-69.

Beatley, T. 1994. Habitat Conservation Planning:Endangered Species and Urban Growth. Austin, Texas: University of Texas Press.

Beatley. Timothy. 1994. Ethical Land Use: Principles of Policy and Planning. Washington, D.C. John Hopkins University Press.

Beatley, T. 1995. Comment: Planning and Sustainability: The Elements of a New (Improved?) Paradigm. Journal of Planning Literature 9, 4: 383-95.

Beatley, Timothy, David J Brower, et al. 1994. An Introduction to Coastal Zone Management. Covelo, California: Island Press.

Benton. Ted. 1993. Natural Relations:Ecology, Animal Rights and Social Justice. London: Verso.

Benyus, Janine M. 1989. The Field Guide to Wildlife Habitats of the Eastern United States. New York: Simon \& Schuster.

Bergman, B.J. 1996. Thinking Like a Mountain:Sierra Club Conference on Conservation Biology. Sierra 81, 1: 21-2.

Berry, Wendell. 1977. The Unsettling of America: Culture \& Agriculture. San Francisco: Sierra Club Books.

Berry, Wendell. 1995. Another Turn of the Crank. Washington, DC: Counterpoint.

Bickford, WE and U.J. Dymon, eds. 1990. An Atlas of Massachusetts River Systems: Environmental Designs for the Future. Amherst, MA: Univ. of Massachusetts Press.

Blankenship, K. 1996. Streamside Forests: Keys to the Living Landscape. American Forests Spring 1996: 13-39. 
Boling, K.C., D. Murphy, M. Goodwin, et al. 1996. Landscape Management in Idaho. Journal of Forestry 94, 2: 16-21.

Boston Globe. 1997. 'Pox" Strikes Florida's Coral Reef: Mysterious Disease Wipes Out 80 Percent of Animals in Some Spots in Year. Boston Globe February 16, 1997: p. A8

Brookshire, D. and M. Mckee. 1994. Is the Glass Half Empty, Is the Glass Half Full: Compensable Damages and the Contingent Valuation Method Natural Resources Journal 34, 1

Brower, David R. and Steve Chapple. 1995. Let the Mountains Talk, Let the Rivers Run: A Call to Those Who Would Sove The Earth. San Francisco: Harper Collins.

Brugman, J. 1994. Who Can Deliver Sustainability: Municipal Reform and The Sustainable Development Mandate. Third World Planning Review 16: 129-46.

Carley, Michael and Ian Christie. 1993. Managing Sustainable Development. Minneapolis: Univ. of Minnesota Press.

Cherfas. J. 1994. How Many Species do we Need? New Scientist 143, 1937: 36-41.

Chiras, Daniel D. 1992. Lessons from Nature: Learning to Live Sustainably on the Earth. Washington, D.C. Island Press.

Chiras. D.D. 1993. Eco-Logic: Teaching the Biological Principles of Sustainability. The American Biologv Teacher 55, 2: 71-6.

Connelly. M. and P. Kennedy. 1994. Must it Be The Rest Against The West? Atlantic Monthly December 1994: 61-91.

Costanza, Robert. ed. 1991. Ecological Economics: The Science and Management of Sustainability. New York: Columbia University Press.

Costanza. R., R. d'Arge, R. deGroot, et al. 1997. The Value Of The World's Ecosystems Services and Natural Capital. Nature 387.6230

Crete, R. 1995. Partnerships for Habitat on Private Land. Endangered Species Bulletin 20, 1: 12-5.

Cronon, William. 1983. Changes in The Land: Indians, Colonists, and the Ecology of New England. New York: Hill and Wang.

Cronon. William. ed 1995. Uncommon Ground: Toward Reinventing Nature. New York: W.W. Norton.

Croonquist, M.J. and R.P. Brooks. 1993. Effects of Habitat Disturbance on Bird Communities in Riparian Corridors. Journal of Soil and Water Conservation 48, 1:65-9.

Daly, Herman E. and John B Cobb.Jr. 1994. For the Common Good: Redirecting the Economy Toward Community, the Environment, and a Sustainable Future. Boston: Beacon Press.

Davis-Ricci, N. and F. Knight. 1993. The Forest: a New York State Wildlife Habitat. Conservationist 48. 1: 2-9.

Dealmeida, O.T. and C. Uhl. 1995. Brazil's Rural Land Tax:Tool for Stimulating Productive and Sustainable Land Uses in The Eastern Amazon. Land Use Policy 12: 105-14. 
Desbonnet. Alan, Pamela Pogue, et al. 1994. Vegetated Buffers in the Coastal Zone: A Summary Review and Bibliography. Naragansett, RI: Coastal Resources Center.

Descola, Philippe. Gellner, Ernest, Jack Goody et al. eds. 1994. In The Society of Nature: A Native Ecology in Amazonia. Cambridge, England: Cambridge University Press.

Dillman, Don A. 1978. Mail and Telephone Surveys: The Total Design Method. Toronto: John Wiley \& Sons.

Dorfman, Robert and Nancy S. Dorfman, eds. 1993. Economics of The Environment: Selected Readings. New York: W.W. Norton.

Dovers, S.R. 1995. A Framework for Scaling and Framing Policy Problems in Sustainability. Ecological Economics 12: 93-106.

Drucker, P.F. 1994. The Age of Social Transformation. Atlantic Monthly 274, 5: 53-80.

Duerksen. Christopher. 1993. Tree Conservation Ordinances: Land Use Regulations Go Green. Chicago: Planning Advisory Service.

Durning, A. 1991. Limiting Consumption:Toward a Sustainable Culture. Futurist 25: 11-5.

Earls, F. and M. Carlson. 1993. Towards Sustainable Development For American Families. Annals of Regional Science 122: 93-121.

Easterbrook, Gregg. 1995. A Moment on the Earth: The Coming Age of Environmental Optimism. New York: Viking Penguin.

Edge, W.D. 1997. Habitat Destruction and Degradation. Internet Website: www. osu.edu; File Name:Habitat.html. Oregon State University.

Ehrlich. P.R. and AH Ehrlich. 1981. Extinction: The Causes and Consequences of the Disappearance of Species. New York. NY: Random House.

Enoksson, B., P. Angelstam, and K. Larrson. 1995. Deciduous Forest and Resident Birds: The Problem of Fragmentation Within a Coniferous Forest Landscape. Landscape Ecology 10. 5: 267-75.

Epenshade, EB and J.L. Morrison, eds. 1978. Goode's World Atlas, 15th Edition. Chicago: Rand McNally \& Co.

Etzioni, Amitai. 1993. The Spirit of Community: The Reinvention of American Society. New York: Simon \& Schuster.

Farber. S. 1991. Intergenerational Transfers and Ecological Sustainability. In Ecological Economics: The Science and Management of Sustainability. Costanza R, ed. New York: Columbia University Press.

Farhig. L. and G. Merriam. 1994. Conservation of Fragmented Populations. Conservation Biology 8, 1: 50-9.

Fogg. George E. 1990. Park Planning Guidelines. Third ed. Alexandria, VA: National Recreation and Park Association. 
Frederickson. H.S. 1996 Tree Ordinance in Coeur d'Alene, Idaho Personal Communication received via Internet e-mail on Feb. 3 '96 regarding Tree Conservation Ordinances.

Gale, R.P. and S.M. Cordray. 1994. Making Sense of Sustainability - Nine Questions to What Should be Sustained Rural Sociologv 59: 311-32.

Gates, David M. 1993. Climate Change and Its Biological Consequences. Sunderland Massachusetts: Sinauer Associates.

Geis, D. and T. Kutzmark. 1995. Developing Sustainable Communities. Public Management August: 413.

Giampietro. M. 1994. Using Heirarchy Theory to Explore the Concept of Sustainable Development. Futures 26: 616-25.

Godschalk, D.R. and Parker, F.H. 1995. Carrying Capacity: A Key to Environmental Planning? In Classic Readings in Urban Planning: An Introduction. Stein JM, ed.New York: McGraw-Hill.

Goldsmith, Edward, Nicholas Hildyard et al. 1990. Imperiled Planet: Restoring Our Endangered Ecosystems. Cambridge, Massachusetts: MIT Press.

Goodland R.H., H. Daly, and J. Kellenberg. 1994. Burden Sharing in the Transition to Environmental Sustainability. Futures 26: 146-55.

Gore, Al. 1992. Earth in the Balance: Ecology and the Human Spirit. New York: Houghton Mifflin.

Graedel, T.E. and Crutzen, P.J. 1989. The Changing Atmosphere. In Managing Planet Earth: Readings from Scientific American. Scientific American, ed New York: W.H. Freeman.

Grumbine, R.E. 1994. Wildness, Wild Use, and Sustainable Development. Environmental Ethics 16, 1

Gunn. B. 1992. Competruism:Ideology with a Sustainable Future. Futures 24: 559-79.

Gunn. Christopher and Hazel Dayton Gunn. 1991. Reclaiming Capital: Democratic Initiatives and Community Development. Ithaca, New York: Cornell University Press.

Haeuber, R. 1996. Setting the Environmental Policy Agenda: The Case of Ecosystem Management. Natural Resources Journal 36. 1: 1-27.

Hansson, Lennart, ed. 1992. Ecological Principles of Nature Conservation: Applications in Temperate and Boreal Environments. London: Elsevier Applied Science.

Harris. T.J. 1996 Marvland's Forest Conservation Act Personal Communication received via Internet e-mail on Feb 1 '96 regarding Tree Conservation Ordinances.

Harte, J. 1996. Defining The 'B' Word (Biodiversity). Defenders Spring 1996

Healey, P. and T. Shaw. 1993. Planners. Plans, and Sustainable Development. Regional Studies 27: 253-8.

Heske. E.J. 1995. Mammalian Abundances on Forest-Farm Edges Versus Forest Interiors in Southern Illinois: 1s There an Edge Effect? Journal of Mammalogy 62, 2: 562-8.

Holmes, B. 1995. There's an Endangered Species on My Land! National Wildlife 33, 4: 8-16. 
Holt, R.D., G.R. Robinson, and M.S. Gaines. 1995. Vegetation Dynamics in an Experimentally Fragmented Landscape. Ecology 76, 5: 1610-24.

Hunken, Jorie. 1994. Ecology for All Ages: Discovering Nature Through Activities for Children and Adults. Old Saybrook. CT: Globe Pequot Press.

International Institute for Environment and Development. Holmberg, Johan, ed. 1992. Making Development Sustainable: Redefining Institutions, Policy, and Economics. Washington, D.C. Island Press.

Jarvis, Frederick D. 1993. Site Planning and Community Design for Great Neighborhoods. Washington. DC: Home Builder Press.

Jurgens, C.R. 1993. Strategic Planning for Sustainable Rural Development. Landscape and Urban Planning 27: 253-8.

Kaiser. Edward J., David R Godschalk, et al. 1995. Urban Land Use Planning. 4th ed. Chicago: University of Illinois Press.

Karplus, K. 1996 Permit Requirement in Santa Cruz, CA. Personal Communication received via Internet e-mail on Feb. 3 '96 regarding Tree Conservation Ordinances.

Kellert. Stephen R and Edward O. Wilson. eds. 1993. The Biophilia Hypothesis. Washington, DC: Island Press.

Kemp, R. 1994. Technology and the Transision to Environmental Sustainability:The Problem of Technological Regime Shifts. Futures 26: 1023-46.

Kendig, Lane. 1980. Performance Zoning. Washington, DC: Planner's Press, American Planning Assoc.

Kim. K.C. and RD Weaver. 1994. Biodiversity and Landscapes: A Parodox of Humanity. Cambridge, England: Cambridge Univ. Press.

Klyza. CM and S.C. Trombulak, eds. 1994. The Future of the Northern Forest. Middlebury, VT: Univ. Press of New England.

Knox, Paul and John Agnew. 1994. The Geography of the World Economy: An Introduction to Economic Geography. 2nd ed. London: Edward Amold.

Knox, Paul L. 1994. Urbanization: An Introduction to Urban Geography. Englewood Cliffs, New Jersey: Prentice-Hall.

Kricher, John C. and Gordon Morrison. 1988. A Field Guide to Ecologv of Eastern Forests: North America. Boston: Houghton Mifflin.

Krueckeberg. D.A. 1995. The Difficult Character of Property: To Whom Do Things Belong? Journal of the American Planning Association 61. 3: 301-9.

Langdon, Steve J, ed. 1986. Contemporary Alaskan Native Economies. Lanham, MD. University Press of America.

Lee, E. 1993. Sharing the Earth. Audobon 95, 2: 106-10. 
Listokin, David and Carole Walker. 1989. The Subdivision and Site Plan Handbook.

Mangel, M., L.M. Talbot, and G.K. Meffe. 1996. Principles For The Conservation of Wild Living Resources. Ecological Applications 6. 2: 338-63.

Marien, M. 1992. Environmental Problems and Sustainable Futures:Major Literature From WCED to UNCED. Futures 24: 731-57.

Marsh, William M. 1991. Landscape Planning: Environmental Applications. 2nd ed. New York: John Wiley \& Sons.

Martin. F. 1994. Sustainabilility, The Discount Rate, and Intergenerational Effects Within a Regional Framework. Annals of Regional Science 28: 7-29.

Martin, M. 1995. A Sustainable Community Profile. Places: A Forum of Environmental Design 9, 3: 30-7.

Massachusetts. 1994. 310 CMR 10.00: Wetlands Protection Act Regulations.

Massachusetts. 1995. ALM GL c. 131: Inland Fisheries and Game. sec. 40. Protection of Flood Plains. Seacoasts, and Other Wetlands; Definitions.

Massachusetts. 1995. 304 CMR 11.00: Forest Cutting Practices.

Massachusetts. 1996. Acts of 1996: The Rivers Protection Act. Ch. 258. The Rivers Protection Act.

Mauritis la Riviere, J.W. 1989. Threats to the World's Water. In Managing Planet Earth: Readings from Scientific American. AnonymousNew York, NY: W.H. Freeman \& Co.

McEuen, A. 1993. The Wildlife Corridor Controversy: A Review. Endangered Species Update 10. 11 \& 12: $1-7$.

McHarg, Ian L. 1991. Design With Nature. New York: John Wiley \& Sons.

McKee, B. 1995. Sustainable Cities. Architecture 84, 7:61-2.

McKibbon. B. 1995. An Explosion of Green. Atlantic Monthly May 1995: 61-83.

Meadows, Donella H., Dennis L Meadows, et al. 1992. Beyond the Limits: Confronting Global Collapse, Envisioning a Sustainable Future. Post Mills. Vermont: Chelsea Green Publishing.

Meier, R.L. 1993. The Way to Sustainability for Poor Cities. Environment and Urbanization 5: 174-85.

Merchant. Carolyn. 1992. Radical Ecologv:The Search for a Livable World. London: Routledge.

Mgonigle, M. 1989. Sustainability and Local Govemment: The Case of the British-Columbia-Islands Trust. Columbia Journal of World Business 32: 524-44.

Milbrath, L.W. 1994. Stumbling Blocks to a Sustainable Society:Incoherences in Key Premises about the Way the World Works. Futures 26: 117-24.

Morrison, M.L., BG Marcot, et al. 1992. Wildlife-Habitat Relationships: Concepts and Applications. Madison. Wisconsin: Univ. of Wisconsin Press. 
Niering. William A. 1985. The Audobon Society Nature Guides: Wetlands. New York: Alfred A. Knopf.

Northern Forest Lands Council. 1994. Finding Common Ground: Conserving the Northern Forest. Concord, New Hampshire: Northern Forest Lands Council.

Noss, R.F. 1997. Issues of Scale in Conservation Biology. In Conservation Biology: The Theory and Practice of Nature Conservation, Preservation, and Management. Fiedler PL, Jain SK, eds.New York, NY: Chapman and Hall.

Noss, Reed F. and Allen Y Cooperrider. 1994. Saving Nature's Legacy: Protecting and Restoring Biodiversity. Washington, D.C. Island Press.

O'Conner. Martin. O'Conner, Martin, ed. 1994. Is Capitalism Sustainable?: Political Economy and the Politics of Ecologv. New York: Guilford Press.

Orians, G.H. 1995. Thought for the Morrow: Cumulative Threats to The Environment. Environment 37. 7: 6-19.

Parenteau, R. 1994. Local Action Plans for Sustainable Communities. Environment and Urbanization 6 : 183-99.

Pease. M. 1995. Sustainable Communities: What's Going On Here? Places: A Forum of Environmental Design 9, 3: 50-69.

Peskin. H.M. 1991. Alternative Environmental and Resource Accounting Approaches. In Ecological Economics: The Science and Management of Sustainability. Costanza R. ed New York: Columbia University Press.

Petit. J.. DL Bassert, et al. 1995. Building Greener Neighborhoods:Trees as Part of the Plan. Washington. D.C. American Forests and NAHB.

Piel. G. 1992. Only One World:Our Own to Make and Keep. New York: W.H.Freeman.

Plater. Zygmunt J.B., Robert H Abrams, et al. 1992. Environmental Law and Policy: Nature, Law, and Society. St. Paul, Minnesota: West Publishing.

Plater, Zygmunt J.B., Robert H Abrams, et al. 1994. Supplement for Environmental Law and Policy: Nature, Law, and Society. St. Paul, Minnesota: West Publishing.

Platt, Rutherford H. 1995. Land Use and Society: Geography, Law, and Public Policy. Coveleto, California: Island Press.

Postel. S. 1994. Carrying Capacity: Earth's Bottom Line. In State of The World 1994: A Worldwatch Inststute Report on Progress Towards a Sustainable World. Brown L, et al. eds.

Povilitis. T. 1995. Changes in Habitat Threaten Biodiversity. Forum For Applied Research and Public Policy Spring 1995: 97-100.

Primack. Richard B. 1993. Essentials of Conservation Biology. Sunderland, Massachusetts: Sinauer Associates.

Ramsey, Meredith. 1996. Community, Culture, and Economic Development: The Social Roots of Local Action. Albany, NY: State University of New York Press. 
Redclift, Michael. 1987. Sustainable Development: Exploring the Contradictions. New York: Methuen.

Redclift. Michael and Ted Benton, eds. 1994. Social Thoery and the Global Environment. London: Routledge.

Rees, W.E. 1995. Achieving Sustainability: Reform or Transformation? Journal of Planning Literature 9, 4: 343-61.

Roberts, P. 1994. Sustainable Regional Planning. Regional Studies 28, 8: 781-7.

Roosevelt, Anna, ed. 1994. Amazonian Indians from Prehistory to Present: Anthropological Perspectives. Tucson, Arizona: University of Arizona Press.

Rowan-Robinson, J., A. Ross, and W. Walton. 1995. Sustainable Development and the Development Control Process. Town \& Country Planning 66, 3: 243-68.

Rowe. Peter G. 1991. Making a Middle Landscape. Cambridge: MIT Press.

Salwasser. H., A.T. Doyle, and W.B. Kessler. 1995. Biodiversity Generates New Views on Old Issues. Forum For Applied Research and Public Policy Summer 1995: 121-3.

Sargent, C. and Bass, S. 1992. The Future Shape of Forests. In Making Development Sustainable: Redefining Institutions, Policy, and Economics. Holmberg J, ed.Washington. D.C. Island Press

Sargent, Frederic O., Paul Lusk, et al. 1991. Rural Environmental Planning for Sustainable Communities. Washington, D.C: Island Press.

Schneider. S.H. 1989. The Changing Climate. In Managing Planet Earth: Readings from Scientific American. Scientific American, ed.New York: W.H. Freeman.

Scientific American. 1989. Managing Planet Earth: Readings from Scientific American. New York: W.H. Freeman.

Selman. P. 1995. Local Sustainability: Can the Planning System Help Us Get from Here to There? Town \& Country Planning $66,3: 287-303$.

Simberloff. D., J.A. Farr. J. Cox, et al. 1992. Movement Corridors: Conservation Bargains or Poor Investments? Conservation Biology 6. 4: 493-504.

Sitarz, Daniel, ed. 1993. Agenda 21: The Earth Summit Strategy To Save Our Planet. Boulder, Colorado: Earthpress.

Smit. B. and M. Brklacich. 1989. Sustainable Development and the Analysis of Rural Systems. Journal of Rural Studies 5: 405-14.

Steiner. Frederick. 1990. The Living Landscape: An Ecological Approach to Landscape Planning. New York: McGraw-Hill.

Sutherland. William J and David A. Hill, eds. 1995. Managing Habitat for Conservation. Cambridge, England: Cambridge University Press.

Templet, P.H. 1995. Grazing The Commons:An Empirical Analysis of Externalities, Subsidies and Sustainability. Ecological Economics 12: 141-59. 
The Global Tomorrow Coalition. 1989. A Guide to "Our Common Future". Washington, DC: Global Tomorrow Coalition.

Tilman. D., R.M. May, C.L. Lehman, et al. 1994. Habitat Destruction and the Extinction Debt. Nature 371. 6492: 65-6.

Town of Charlton. 1989. Subdivision Regulations. Charlton, MA: Planning Board.

Town of Charlton. 1997. Zoning Bylaw. Amended to May 1997 ed. Charlton. MA:

United Nations Conference on Environment and Development. 1993. Agenda 21: Programme of Action for Sustainable Development. New York, N.Y. United Nations Dept. of Public Information.

Unknown. 1996 Public Trees in Seattle, Washington Personal Communication received via Internet email on Feb 2 '96 regarding Tree Conservation Ordinances.

Vandenbergh, J. and P. Nijkamp. 1995. Modelling Ecologically Sustainable Economic Development in a Region: A Case Studey in the Netherlands. Annals of Regional Science 28: 7-29.

Vanmansvelt, J.D. and J.A. Mulder. 1993. European Features for Sustainable Development: A Contribution to The Dialogue. Landscape and Urban Planning 27:67-90.

Walker. R. and Craighead, L. 1997. Analyzing Wildlife Movement Corridors in Montana Using GIS. Internet Website: www. mcn.net -amwild: File Name:lcpcor.html. American Wildlands.

Welner. J. 1995. Natural Communities Conservation Planning: An Ecosystem Approach to Protecting Endangered Species. Stanford Law Review 47, 319: 319-61.

White, P.S. 1995. Conserving Biodiversity: Lessons from the Smokies. Forum For Applied Research and Public Policy Summer 1995: 116-20.

Wilbert. C. 1996. Wilderness and Working Landscapes. Town \& Country Planning 65, 2: 52-3.

Wildlands. A. 1997. Corridor Analysis Project. Internet Website: www. mcn.net/amwild: File Name:col.html. American Wildlands.

Williams. T. 1996. What Good is a Wetland? Audobon November-December: 82-100.

Williams. T. 1997. Ways of the Wild. Wildlife Conservation 100, 1:22-9.

Wilson. B.C. 1995. The Mianus Watershed Bioregional Planning Project. Places: A Forum of Environmental Design 9, 3: 18-21.

Wilson. E.O. 1989. Threats to Biodiversity. In Managing Planet Earth: Readings from Scientific American. Scientific American, ed.New York: W.H. Freeman.

Wilson. E.O. 1992. The Diversity of Life. Cambridge, MA: Harvard University Press.

Wimberley, R.C. 1993. Policy Perspectives on Social, Agricultural, and Rural Sustainability. Rural Sociologv 58: 1-29.

Woodley, Stephen, James Kay et al. eds. 1993. Ecological Integrity and the Management of Ecosystems. Ottawa, Canada: St. Lucie Press. 
World Commission on Environment \& Development (WCED). 1987. Our Common Future. Oxford. NY: Oxford University Press.

World Resources Institute. 1992. Biodiversitv in Freshwater Svstems. Internet Website: www. wri.org: World Resources Institute.

Yanarella. E.J. and R.S. Levine. 1992. Does Sustainable Development Lead to Sustainability? Futures 24: $731-57$.

Yaro. Robert D., Randall G Arendt, et al. 1993. Dealing with Change in the Connecticut River Valley: A Design Manual for Conservation and Development. Amherst, Massachusetts: Lincoln Institute of Land Policy. 